\title{
MARCOS CÂMARA DE CASTRO
}

\section{O ORIGINAL EVIDENTE EM FRUCTUOSO VIANNA: AS CANÇÕES}

Tese apresentada ao Departamento de Música da Escola de Comunicações e Artes da Universidade de São Paulo, como exigência parcial para a obtenção do título de Doutor em Musicologia.

Orientador: Prof. Dr. Mario Ficarelli

Campinas (SP)

2007 
"Levei um solavanco danado com a Dança de Negros bem feita como o diabo (você sabe que ele é ótimo pianista), mas percebendo na benfeitoria da peça, um banal disfarçado, que em geral é o que me irrita muito nos franceses".

(Carta de Mario de Andrade a Manuel Bandeira) 
${ }^{1}$ Bilhete de Carlos Drummond de Andrade:

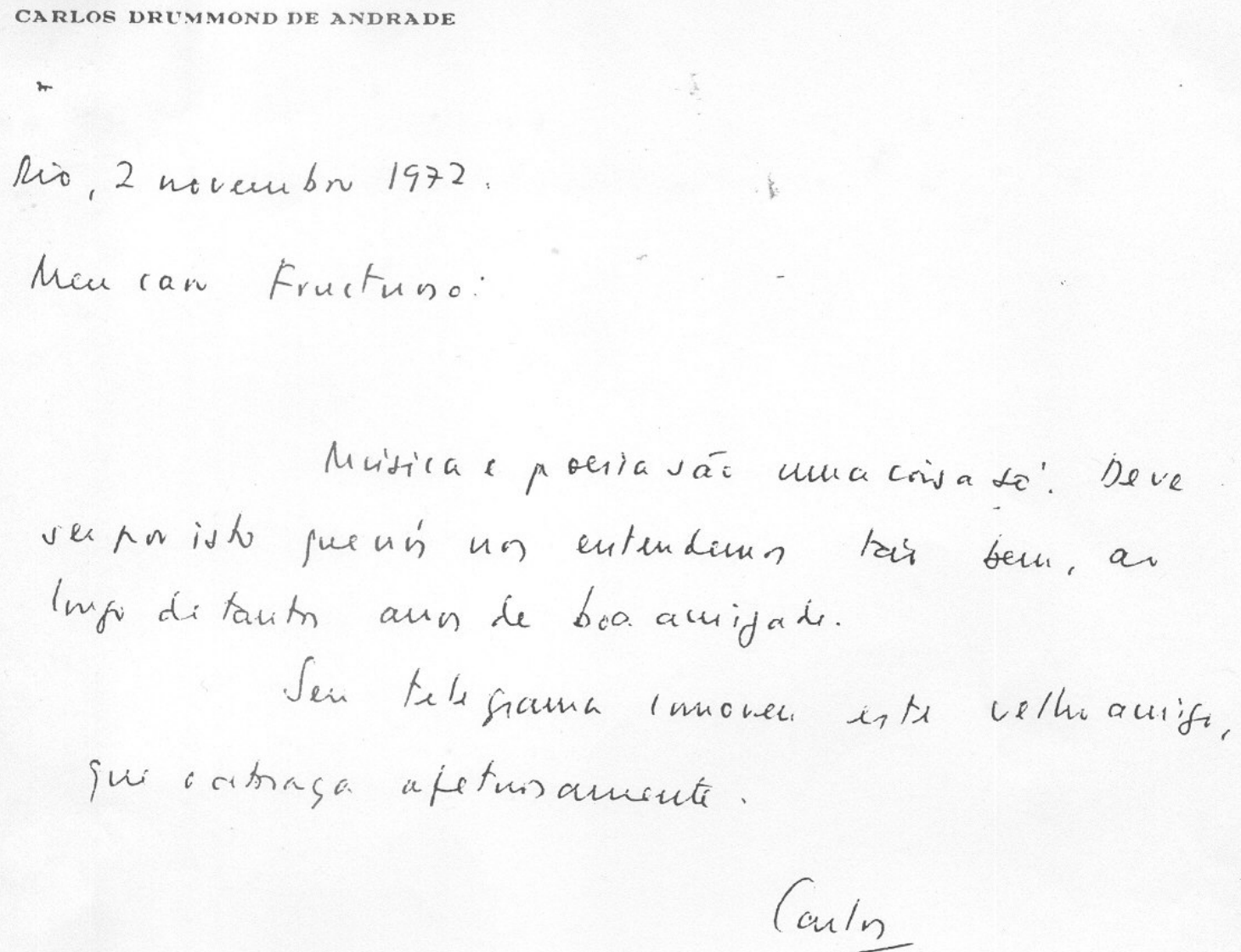

${ }^{1}$ Rio, 2 de novembro de 1972. Meu caro Fructuoso: Música e poesia são uma coisa só. Deve ser por isto que nós nos entendemos tão bem, ao longo de tantos anos de boa amizade. Seu telegrama comoveu este velho amigo, que o abraça afetuosamente. Carlos 
ÍNDICE:

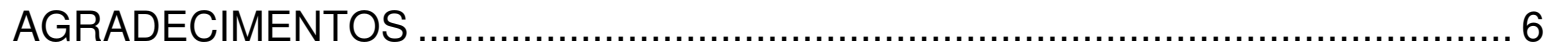

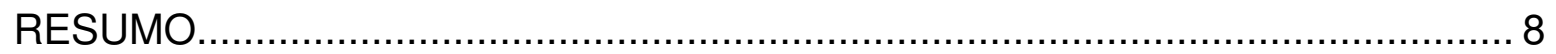

ABSTRACT …

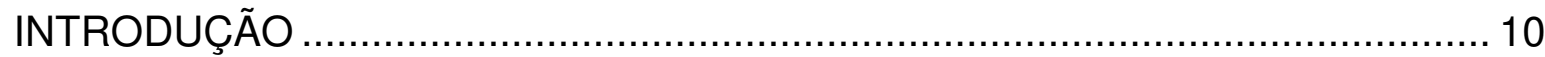

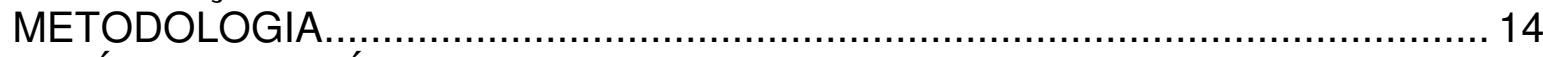

CAPÍTULO 1 - A ÉPOCA DE FRUCTUOSO VIANNA ................................... 17

CAPÍTULO 2 - O ORIGINAL EMBRIONÁRIO, O "BANAL DISFARÇADO" OU O

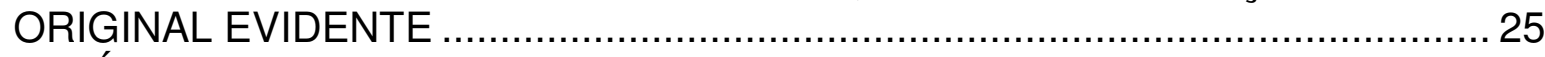

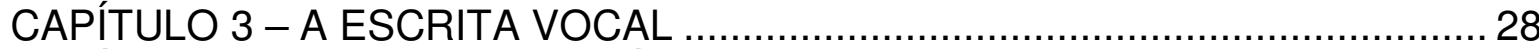

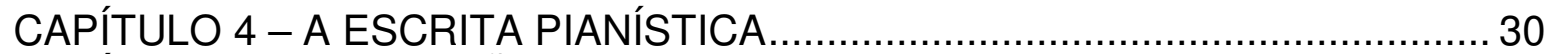

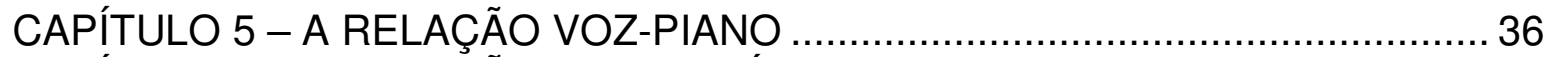

CAPÍTULO 6 - A RELAÇÃO TEXTO-MÚSICA ……................................... 47

CAPÍTULO 7 - AS FORMAS MUSICAIS …............................................ 54

CAPÍTULO 8 - CONCLUSÃO: NÃO É UM COMPOSITOR MENOR! ................. 70

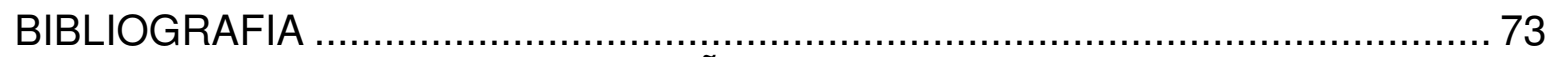

ANEXO 1: A INTEGRAL DAS CANÇÕES ....................................................... 76 
Para Guigui, sempre.

Para Carla, companheira, mulher da minha vida. Para Felipe, Pedro e Chico. 


\section{AGRADECIMENTOS}

Ao Compositor Mario Ficarelli, pela sensibilidade, carinho e força; Ao Maestro Olivier Toni, pelos ensinamentos, À Sílvia e à Marina, da Seção Multimeios da ECA, pelo apoio. 
CASTRO, Marcos Câmara de

"O Original Evidente em Fructuoso Vianna: as Canções"

Campinas, ECA, 2007

Tese (Doutorado)

1 - A Canção de Câmara Brasileira; 2 - Música Brasileira do Século XX; 3 - Modernismo; 4 - Nacionalismo; 5 - Análise Musical. 


\section{RESUMO}

Através de análises detalhadas de suas canções, este trabalho tem dois objetivos principais: 1) demonstrar a grandeza e a importância da obra de Fructuoso Vianna na história da música brasileira, através do estudo de seu idiomático; e 2) colocar à disposição do público uma edição crítica e completa de sua canção de câmara, para estudo, performance e divulgação. Vianna desenvolveu sua linguagem ao mesmo tempo em que no Brasil e no mundo conviviam as mais diferentes poéticas musicais. No período que vai de seu nascimento, 1896, até sua morte, em 1976, o mundo assistiu ao drama musical wagneriano, ao modernismo de Debussy, à revolução solitária de Stravinsky, ao charme de Ravel, às experiências com a atonalidade realizadas pela II Escola de Viena, ao pancromatismo de Bártok, ao serialismo etc. Especificamente em nosso país houve a questão do nacionalismo ${ }^{2}$ veementemente preconizada por Mário de Andrade, para a qual Vianna também não fechou os olhos (influência que, no entanto, não deve ser superestimada). Ao longo destas páginas será possível constatar que Vianna tinha propósitos claros de escrita vocal e pianística, carregando de sentido uma palavra de acordo com sua necessidade de expressão e, sempre que necessário, conferindo ao piano uma função que ambienta, situa, completa e enriquece os significados do texto. Um dos protagonistas da criação da canção brasileira, de 1928 (Sonâmbula ${ }^{3}$ ) a 1966 (Ave Maria), ou seja, durante toda sua vida produtiva, Vianna compôs canções ${ }^{4}$.

\footnotetext{
2 "uma desastrosa interpretação errada do que deveria ser música brasileira", segundo Gilberto Mendes. (In ÁVILA, 1976, p. 131).

${ }^{3}$ Toda a ortografia foi atualizada.

${ }^{4}$ Ao contrário do que diz Vasco Mariz: "Todas as peças de valor e que tanto se vulgarizaram, como a Dança de Negros, Toada n. 3, Corta-jaca e Miniaturas, estão contidas num espaço de oito anos, que vai de 1924 a 1932. Esse, acredito, foi o período áureo da composição de Fructuoso Vianna. De sua obra mais recente só a Toada n. 6 merece igual atenção". In. MARIZ, Vasco. A canção brasileira. Rio de Janeiro, Francisco Alves-ABM, 2002, pp: 113-117. Obs.: Essa afirmação absolutamente equivocada - que insiste em permanecer nas novas edições desse livro - baseiase num artigo publicado por Mariz em 1948, também reproduzido em Figuras da Música Brasileira Contemporânea, Brasília UnB, 1970. Em conversa particular com o escritor-diplomata, por ocasião da entrega do I Prêmio ABM de Monografia, pude ouvir que, devido à viagem que faria logo depois para Israel, como Embaixador, o autor não revisou nunca mais este capítulo dedicado a Vianna.
} 


\section{ABSTRACT}

Through the detailed analysis of his songs, this work has two main goals: 1) demonstrate the greatness and importance of Fructuosos Vianna's creation in Brazilian classical music's history, through the study of his idiomatic; and 2) make possible to the public to reach a critic and complete edition of his chamber music for performance and disseminate. Vianna developed his language while in Brazil and everywhere else in the world a huge assortment of aesthetic tendencies was not always in harmony - living together. In the period comprehended between his birth date, 1896, and his death, 1976, the world had attended to the musical drama of Wagner's, the modernism of Debussy's, the lonely revolution of Stravinsky's and the charm of Ravel's, the experiences with the atonality made by the II Viennese School, the panchromatism of Bartok's, the serialism, etc. Specifically in our country there was the discuss of the nationalism ${ }^{5}$ vehemently praised by Mário de Andrade, who Vianna didn't forget to consider (influence that, however, can't be overestimated). Through these pages it will be possible to verify that Vianna had clear vocal writing and pianistic proposes, loading with meaning a word according to his urges of expression and, whenever necessary, conferring to the piano a finality that creates and environment, places, completes and enriches the meanings of the text. One of the protagonists of the creation of the Brazilian song, from 1928 (Somnambulist) to 1966 (Ave Maria), through all his productive life, Vianna has composed songs ${ }^{6}$.

\footnotetext{
5 "a disastrous wrong interpretation of what should be Brazilian music", according to Gilberto Mendes (In ÁVILA, 1976, p. 131).

${ }^{6}$ Opposite to what is told by Vasco Mariz, that is, Mariz says: "All the valuable pieces which are so vulgarized like Dança de Negros, Toada n. 3, Corta-Jaca and Miniaturas were composed within 8 years, from 1924 to 1932. I believe that this was the golden period of Fructuoso Vianna creation. From his more recent works only Toada N. 6 deserves the same attention". In MARIZ, Vasco. A canção brasileira. Rio de Janeiro, Francisco Alves-ABM, 2002, pp: 113-117. Obs.: This assertion is completely wrong in spite of being always published in the new editions of that book and is based in an article published by Mariz in 1945. In a private talk with him, during the delivery of the I ABM Award of Monography, I could hear that Mr. Mariz never revised this chapter dedicated to Vianna.
} 


\section{INTRODUÇÃO}

Na década de oitenta (minha turma de Graduação ingressou em 1977), meu amigo Eduardo Inke ${ }^{7}$, em sua casa, tocou-me ao piano os Jogos Pueris (1929). Esse foi o ponto de partida para que eu começasse a pesquisar o repertório de Vianna, que me impressionou pela síntese que realizou espontaneamente entre 0 brasileiro e o universal. Fui então procurar o que havia sobre ele e, graças aos esforços de D. Juju, Anna Maria e Guigui ${ }^{8}$, as principais bibliotecas de São Paulo (e do Brasil!) tinham cópias de suas partituras - inclusive as da ECA e do CCSP ${ }^{9}$. Anna Maria morava em um apartamento no bairro dos Jardins, em São Paulo, que passei a freqüentar para falarmos de Vianna e outros assuntos musicais. MostreiIhe vídeos de trabalhos meus, tanto de regências como de composições, e ela apresentou-me vários manuscritos de seu pai e emprestou-me as duas fitas do depoimento do MIS do Rio de Janeiro, realizado em 1971. Degustei-o em cada pormenor: cada frase, o sotaque mineiro daquele senhor de 75 anos, as ironias ${ }^{10} \ldots$ Havia um espaço no apartamento de Anna Maria que era o protótipo de um "Museu Fructuoso Vianna"11, com manuscritos, fotos, recortes, gravações, todo o acervo que hoje se encontra na Seção Multimeios da Biblioteca da ECA.

Em 1988, embarquei para uma permanência de dois anos em Paris, França, para estudar com Michel Philippot, como "auditeur-libre", no $\mathrm{CNSM}^{12}$, com bolsa de Aperfeiçoamento do $\mathrm{CNPq}^{13}$. De lá, escrevi a Anna Maria um cartão postal dizendo que eu escreveria o livro sobre seu pai. Quando voltei ao Brasil, em 1990,

\footnotetext{
${ }^{7}$ Eduardo Inke é músico, pastor presbiteriano e reside atualmente nos EUA.

${ }^{8}$ Maria Júlia Brasil Vianna com quem se casou em 1931; Maria Guilhermina Brasil Vianna (nascida em 1933) e Anna Maria Brasil Vianna (falecida em 2003), suas filhas.

${ }^{9}$ Escola de Comunicações e Artes da Universidade de São Paulo e Centro Cultural São Paulo (Secretaria Municipal de Cultura).

10 Sobre Villa-Lobos: " - Com esse ninguém pode!". Sobre sua suposta prisão: " - Eu nunca fui preso; sou preso aos encantos femininos." Sobre H. Oswald: " - Ele era assim uma espécie de sacerdotisa". Sobre parcerias na composição de música e letra: " - Um dia eu vou fazer o contrário: pedir para um poeta musicar um poema meu". Sobre o "nacionalismo" de Francisco Braga: " - $A$ gente percebe que o Braga não está na dele".

${ }^{11}$ Projeto, aliás, que ainda insisto a cada mudança de gestão na Secretaria de Cultura de Itajubá (MG)...

${ }_{12}$ Conservatoire National Supérieur de Musique - Paris.

${ }^{13}$ Conselho Nacional de Pesquisa.
} 
não demorou para que ela me escrevesse, convidando-me para visitá-la. Em sua casa, fez um brinde: “ - Fructuoso não morreu?'; convidando-me para um recital que Sônia Goulart ${ }^{14}$ faria na Fundação Moreira Salles, de Poços de Caldas (MG), para a inauguração de um piano Steinway recém-comprado para aquela sala de concertos. No dia 28 de março de 1993, fomos a Poços de Caldas eu e meu colega Paulo Castagna ${ }^{15}$ - que, na época, estava envolvido comigo no resgate da obra de Fructuoso. Anna Maria faleceria 11 dias depois e aquela cena em seu apartamento fez-me pensar: ela "passou-me o bastão". Em 1998, ingressei no Mestrado da ECA/USP sob a orientação do Compositor e Livre-Docente Mario Ficarelli, que gentilmente aceitou-me para sua única vaga. Escolhi Vianna como tema da Dissertação, para dar conclusão a essa "história-de-amor-à-primeiravista" que começou por volta de 1985.

Ainda com relação à Anna Maria, na retomada de nosso contato, entre $1992 \mathrm{e}$ 1993, ela encomendou-me a transcrição daquele depoimento do MIS. Senti que, além da necessidade histórica da transcrição, havia também, de sua parte, uma forma de retribuir ao meu interesse pela obra de seu pai ${ }^{16}$. Com seu precoce falecimento, a continuidade da pesquisa ficou comprometida. Ocupei-me com outras atividades até que em 1998 iniciei contato com a Guigui através de carta em que Ihe contei toda a história de forma resumida. Pedi sua autorização por escrito para pesquisar a obra de Vianna e começamos a acertar uma ida minha ao Rio de Janeiro, onde ela morava. Na Sexta-feira Santa de 1998 cheguei ao Rio para visitá-la. Expus meus pontos de vista e ela concordou em doar à ECA o Acervo Fructuoso Vianna - que tinha sido transferido para o Rio de Janeiro. Fui buscá-lo como "representante legal" da ECA e todo o Acervo foi catalogado sob a

14 A pianista bahiana Sônia Goulart é detentora de mais de 30 prêmios nacionais e internacionais, incluindo, entre outros, o $1^{\circ}$ Prêmio da Televisão em Frankfurt na Alemanha, prêmio do Rencontres Musicales Internationales em Bruxelas na Bélgica e prêmio no concurso internacional Ferrucio Busoni em Bolzano na Itália.

${ }^{15}$ Paulo Castagna graduou-se e apresentou dissertação de Mestrado na Escola de Comunicações e Artes da Universidade de São Paulo e defendeu tese de doutorado na Faculdade de Filosofia, Letras e Ciências Humanas da USP. É professor e pesquisador do Instituto de Artes da UNESP.

${ }^{16}$ Essa transcrição, que é o ANEXO 3 de minha Dissertação de Mestrado, será em breve transformada em artigo científico, com notas de rodapé explicativas, introdução, comentários etc. 
coordenação do Professor Lorenzo Mammi, então diretor do extinto LAM ${ }^{17}$, com o eficiente trabalho de alunos graduandos, bolsistas da FAPESP ${ }^{18}$.

Liguei para o Aluísio de Alencar Pinto, pianista cearense residente no Rio de Janeiro, que foi um dos entrevistadores de Vianna no depoimento do MIS, mas ele negou-se a dar qualquer informação gratuita... Essa experiência foi no entanto de extrema utilidade porque resolveu-me um problema formal da Dissertação de Mestrado: passei a pensar o depoimento não como perguntas-e-respostas mas separando-o por temas, em capítulos. Foi a forma que encontrei para abranger toda sua vida e acrescentar às suas declarações uma contextualização histórica.

Foram tomadas diversas medidas junto a meu orientador para a cerimônia de doação do Acervo. Enviei uma matéria para a Revista Concerto e Nélson Kunze, seu diretor, houve por bem publicá-la na edição de Agosto ${ }^{19}$ daquele ano. O Jornal da USP também publicou nota sobre a doação ${ }^{20}$, cuja cerimônia teve lugar no Departamento de Música da ECA-USP, no dia 13 de agosto de 1998, às $12 \mathrm{~h}$, no "Auditório Olivier Toni", precedida de um recital de violino e piano e piano solo ${ }^{21}$, com as presenças da Guigui, do então diretor da ECA, Tupã Gomes Corrêa, Mario Ficarelli, entre outros. Em seu discurso, Ficarelli falou da importância de se tornar público o acesso aos acervos dos compositores, criticando o egoísmo daqueles que se apropriam de originais e manuscritos e se negam a compartilhar 0 patrimônio com a sociedade. Minha fala foi a respeito da experiência narrada nesta introdução. A dissertação de mestrado acabou por ser publicada em livro ${ }^{22} \mathrm{e}$ mereceu meia página do "Estadão"23.

17 Laboratório de Musicologia do Depto. de Música. O acervo FRUCTUOSO VIANNA consta de cerca de 75 partituras manuscritas, em larga parte autógrafas, além de um farto material documentário, incluindo fotos, cartas, artigos e outros documentos.

${ }^{18}$ Fundação de Amparo à Pesquisa do Estado de São Paulo.

${ }^{19}$ Acervo de Fructuoso Vianna é doado à USP, Revista Concerto, agosto de 1998, p. 7.

20 "Partituras manuscritas do Modernismo estão na USP". Jornal da USP, de 28/9 a 4/10 de 1998, p. 17.

${ }^{21}$ Fabian Fernandes (violino) e Renato Figueiredo (piano) executaram o Canto Elegíaco (1922) e Cínthia Priolli interpretou as Sete minaturas sobre temas brasileiros (1932).

${ }^{22}$ Vencedora do I Concurso ABM de Monografia - atual Prêmio "José Maria Neves" -, a obra, Fructuoso Vinanna, orquestrador do piano, foi publicada em livro pela ABM Editorial em 2003.

${ }^{23}$ SAMPAIO, João Luiz. "Fructuoso Vianna redescoberto". O Estado de São Paulo, 21 de dezembro de 2003, p. D5. 
UNIVERSIDADE DE SÃO PAULO

ESCOLA DE COMUNICAÇÕES E ARTES

eco

AUDITÓRIO DO DEPARTAMENTO DE MÚSICA DA ECA-USP

Dia 13/08/1998 às $12 \mathrm{~h} 30 \mathrm{~min}$.

\section{Cerimônia de Doação Oficial do Acervo Fructuoso Vianna}

\section{Recital}

Programa

Canto Elegíaco, Op. $1 n^{\circ} 3$

Fabian Figueiredo, violino

Renato Figueiredo, piano

Sete Miniaturas sobre Temas Brasileiros

Cinthia Priolli, piano

Comissão de Divulgação e Eventos do Departamento de Música da ECA-USP

Av. Prof. Lúcio Martins Rodrigues, 443 - Cidade Universitária - CEP 05508-900 - São Paulo - SP - Brasil Telefone: (011) 818-4477 - Telefax: (011) 813-0596 - 814-4764 e 818-4283 


\section{METODOLOGIA}

Toute forme musicale est construite, comme une demeure, comme une machine, comme un poème ${ }^{24}$

(COEUROY, 1951)

Ideally speaking, it (form) is felt to be something vital and growing, an organism, rather than a mould or framework ${ }^{25}$

(MORRIS, 1972)

Para as análises específicas das canções, buscou-se num primeiro momento extrair de cada uma o seu sentido fenomenológico ${ }^{26}$ próprio; a partir daí, quando foi possível fazê-lo, adequá-lo às formas elementares definidas na bibliografia específica. Foram extraídas das obras categorias próprias que constituem o idiomático da linguagem vianniana, com o intuito de estabelecer padrões e procedimentos do autor e de como esses padrões dialogam com o repertório analítico atual. Por exemplo, das 23 canções, 13 delas têm consistentes prelúdios, interlúdios ou poslúdios pianísticos que sugerem seções formais completas - 0 que confere à parte instrumental, como em Schumann, igual importância no discurso. Seus períodos melódicos não são necessariamente simétricos, muitas vezes fundando suas composições em sucessões de frases que encerram idéias prontas, sem fazer parte de um período, dentro da quadratura. Suas harmonias são recheadas de quartas, sextas, sétimas, nonas e acordes que buscam antes um efeito timbrístico do que uma tensão harmônica e, como tal, foram analisadas; e seus finais privilegiam as cadências de engano. Em Vianna, o aspecto harmônico é parte integrante da textura geral cujas relações funcionais são menos importantes do que certos efeitos timbrísticos - bem à maneira do século vinte - e

\footnotetext{
24 "Toda forma musical é construída, como uma habitação, como uma máquina, como um poema".

25 "Idealmente falando, é como se isto (a forma) fosse para ser algo vital e crescente, um organismo, mais do que um molde ou uma moldura".

${ }^{26}$ O substantivo feminino "fenomenologia", aqui entendido apenas como uma "derivação por extensão de sentido", sem qualquer implicação filosófica: "qualquer formulação teórica (...) que busque ressaltar descritivamente a experiência vivida da subjetividade, em detrimento de princípios, teorias ou valores preestabelecidos". In HOUAISS, Antonio e VILLAR, Mauro de Salles. Dicionário Houaiss da Língua Portuguesa. Rio de Janeiro, Objetiva, 2001.
} 
parente próximo da música francesa de Fauré, Debussy e Ravel, com suas ambientações calcadas na sonoridade produzida pela combinação dos intervalos - grande conhecedor que era de seu instrumento. Como diz White: "Today (...) harmony itself appears currently to be of lesser relative importance as an expressive element than previously. The elements of melody, rhythm, and, above all, sound seem to dominate the thinking of the progressive composers of today"27. A análise funcional só é necessária quando realmente as relações harmônicas adquirem uma relevância significativa, como em Resume of life (1966) em que abundam acordes jazzísticos ou na Ave Maria (1966), que faz giros em torno do tom principal, passeando por tons vizinhos e por modulações cromáticas. No geral, o padrão fenomenológico foi o adotado, já que: "Such data is meaningful only when viewed in relation to the phenomena of melody, rythm, and sound within the total growth process of the work" ${ }^{\prime 2}$. Dependendo da obra, uma ferramenta analítica diferente foi utilizada: com freqüência o canto surge apenas como uma das vozes da polifonia e como tal foi considerado; em outras ocasiões, o canto tem uma pulsação própria, diferente e, às vezes, oposta ao piano, criando polimetrias.

White ${ }^{29}$ chama de Estruturas Normativas a taxonomia dos estereótipos formais e estruturais da música ocidental. O objetivo do analista não seria tanto determinar as intenções do compositor mas sim analisar os resultados musicais. Como diz Lutoslawsky ${ }^{30}$ :

27 WHITE, John D.. Comprehensive Musical Analysis. Lanham, Maryland and Oxford, The Scarecrow Press, Inc., 1994, p. 140: "Hoje em dia a Harmonia aparece freqüentemente tendo menos importância relativa como um elemento expressivo do que outrora. Elementos como melodia, ritmo, e, acima de tudo, som parecem dominar o pensamento dos compositores progressistas de hoje".

28 Idem, ibidem, p. 141: "Tais dados são significativos somente quando vistos em relação aos fenômenos de melodia, ritmo e som com o processo total de desenvolvimento da obra".

${ }^{29}$ Idem, ibidem, p. 90.

30 In NORDWALL, Ove. Lutoslawsky. Stockholm, Wilhem Hansen, 1968, p: 121: "O principal objetivo de uma peça musical é que ela deverá ser experimentada pelo ouvinte. Conseqüentemente conclui-se que uma obra de arte é um fenômeno complexo, a maior parte do qual - de acordo com o plano de seu propósito - é para atingir a mente humana. (Estou aqui excluindo todos os problemas subordinados em relação à arte, e limitando-me ao processo real de criação e recepção). Como resultado do reconhecimento do aspecto psicológico da arte como sendo um panorama, oponho-me a todos que consideram a existência da obra em si mesma, independentemente de ser percebida, como principal objetivo de ter sido criada. A partitura ou gravação são certamente muito necessárias para a existência de uma peça musical. No entanto, 
The main pourpose of a piece of music is that it should be experienced by the listener. Consequently it follows that a work of art is a complex phenomenon, the main part of which - according to the design of its pourpose - is to play on the human mind. (I am here excluding all subordinate problems connected with art, and limit myself to the actual process of creation and reception). As a result of recognizing the psychological aspect of art as being paramount, I am opposed to all those who consider the existence of a work in itself, independent of its being perceived, as the main aim of its being created. The score or recording are quite certainly necessary for the existence of a piece of music. However, they are not in themselves the actual musical work but only a stage in its realization, which is fully achieved only when the work is experienced by the listener. I understand the process of composing above all as the creation of a definite complex of psychological experiences for my listener, the fulfillment of which is on the whole extended throughtout the greater number of performances of the same work (...). Thus, for instance, all elaborate methods of organizing musical material can only be of value in that they produce a particular experience for the listener, as intended by the composer - even if this is only achieved after the work has been heard many times.

não são em si mesmas a obra de arte verdadeira, senão um estágio da sua realização, que só é plenamente atingida somente quando a obra é experimentada pelo ouvinte. Entendo o processo de composição acima de tudo como um definido complexo de experiências psicológicas para meu ouvinte, cuja total realização se dá através do maior número de interpretações da mesma obra (...). Assim, por exemplo, todos os métodos elaborados de organização do material musical só pode ter valor se produzem uma experiência particular para o ouvinte, tal como pretendida pelo compositor - mesmo se isso é atingido depois que a obra tenha sido ouvida várias vezes." 


\section{CAPÍTULO 1 - A ÉPOCA DE FRUCTUOSO VIANNA}

Fructuoso nasceu no ano da morte de Carlos Gomes (1896). O Brasil ainda "se afina com um dos aspectos da produção européia oitocentista: a ópera italiana"31. Época também da composição de Noite Transfigurada (1899), de Schönberg. A música brasileira culta tinha representantes como: Alexandre Levy (1864-1892), Leopoldo Miguez (1850-1902), Henrique Oswald (1854-1931) - que foi professor de Vianna -, Alberto Nepomuceno (1864-1920), Francisco Braga (1868-1945) e Glauco Velasquez (1884-1913). A música popular brasileira surgia como resultado da mistura de elementos melódicos portugueses, rítmica africana (oriunda de diversas regiões do continente negro) e da herança ameríndia. Assim define $\mathrm{Paz}^{32}$ :

(...) Heitor Villa-Lobos, que inaugura uma nova realidade e concede à música no Brasil uma hierarquia mais alta, é quem põe, em princípio, os elementos autenticamente derivados da tríplice corrente cultural (...) do século XIX. A essa tendência encorajadora do cultivo do autóctono se congregam Joaquim Barroso Neto, Luciano Gallet, Fructuoso Vianna, Hekel Tavares, Brasílio Itiberê, Francisco Mignone, Lorenzo Fernandez, Assis Republicano, Radamés Gnatalli, Camargo Guarnieri, Luís Cosme.

Nessa época, consolidava-se no Brasil a Primeira República, que tinha como base a Constituição de 1891 e cujo principal mecanismo foi a "política dos governadores", em que o governo federal trocava o apoio das bancadas estaduais no congresso pela garantia de ampla autonomia das oligarquias em seus estados. Como conseqüência, as oposições enfraqueceram-se, dando margem à fraude eleitoral e à exclusão da maioria da população das decisões políticas. Como o voto era aberto e o reconhecimento dos candidatos era feito pelo Poder Legislativo, a influência do presidente e dos governadores sobre o congresso propiciava a prática da "degola" dos candidatos indesejáveis.

\footnotetext{
${ }^{31}$ In PAZ, Juan Carlos. Introdução à música de nosso tempo. São Paulo, Duas Cidades, 1976, p. 391.

${ }^{32}$ Idem, ibidem.
} 
Gilberto Mendes, num texto de $1975^{33}$, afirma:

Entendida a música como linguagem, desfazem-se todas aquelas velhas questões entre forma e conteúdo, música nacional e cosmopolita, tão ao gosto brasileiro, pois constataremos que ela é uma só em toda a arte do Ocidente. Da Grécia antiga aos nossos dias, através de um processo evolutivo que parte do sistema modal com base no estudo do fenômeno acústico até chegar ao microtonalismo concreto-eletrônico. Inicialmente na Europa, depois ampliado para as Américas em seus últimos estágios, numa trajetória comandada ora pelos gregos, franceses, italianos, alemães ou flamengos. $E$, atualmente, também pelos americanos. (...) E a música brasileira é um dos aspectos dessa linguagem, em sua ramificação para as Américas, no período Barroco, quando ela se manifestou pela primeira vez entre nós, principalmente em Minas Gerais. Primeiramente ela é barroca, depois diremos que é brasileira. Da mesma forma, quando ouvimos Vivaldi, falamos em música barroca, não em música italiana. O que não nega o fato de que ela é música barroca italiana, como a nossa é música barroca brasileira, na maneira como seus compositores utilizaram um mesmo conjunto de estruturas significantes; e sobretudo pelas contribuições pessoais deles, na elaboração de signos novos que vieram enriquecer esse conjunto estrutural.

\section{Ou, nas palavras de Ferreira Gullar ${ }^{34}$ :}

Não se trata, evidentemente, de uma cultura brasileira. Não se trata, evidentemente, de uma cultura própria, especificamente nacional, mas cultura brasileira no sentido de aglutinação dinâmica de elementos reelaborados que, através das décadas, se mantêm ligados e ativos numa interação capaz de responder ao presente e ajudar na sua formulação.

Mais adiante, Mendes analisa a entrada no século XIX e os reflexos da "multiplicidade de caminhos" que o Romantismo abriu: a introdução do tema popular dentro do esquema formal clássico realizada por Brasílio Itiberê; a síntese dos elementos estruturais afro-espanhóis que redunda no maxixe de Nazareth, continuador das pesquisas de Alexandre Levy; compara as influências de Chopin e Schumann sobre Nazareth e sobre Gershwin, nos EUA, e continua:

\footnotetext{
${ }^{33}$ In ÁVILA, 1975, pp.: 127-137

${ }^{34}$ GULLAR, 1978, p. 46.
} 
...seria nas três primeiras décadas deste século (século $X X$ ) que ela explodiria como música americana, de um novo mundo, juntamente com os EUA, México, Argentina, Cuba e outros países do continente. Surgem então seus primeiros inventores e, mais do que isso, sua maior invenção: a música popular urbana, o jazz, o tango, a rumba, o samba, primeiras manifestações na história da música de uma cultura de massas.

Esses dois níveis de realização paralelos seriam portanto o aspecto novo da linguagem musical moderna: "o jazz fornecendo estilemas a Stravinsky, Ravel, Milhaud, Bártok"; a sintetização da célula rítmica do maxixe realizada por Nazareth, o som das bandas que acompanhavam Noel Rosa e, depois, nos anos 50, a batida da bossa-nova etc. Fructuoso Vianna chegou ao Rio de Janeiro em 1912 e, no ano seguinte, ingressou na classe de Henrique Oswald. Diplomou-se em piano, em 1919 - mesmo ano em que conhece Villa-Lobos através do violoncelista Newton Pádua. Em 1920, integra o "Trio Brasileiro", com Ronchini e Pádua; e o Quinteto que trouxe o Rei Albert I, da Bélgica, em conhecida viagem ao Brasil, no Encouraçado São Paulo. Ganharia ainda o segundo prêmio por seu Prelúdio $n^{\circ} 1$ em concurso realizado pela Sociedade de Cultura Musical do Rio de Janeiro. Em 1921, compõs sua Serenata Espanhola, iniciou-se no magistério pianístico e participou da famosa audição privada, para Arthur Rubinstein, no Palace Hotel, executando obras de Villa-Lobos.

Fundado em 1922, o Partido Comunista do Brasil (PCB) conheceu a legalidade até 1927. Durante a "Semana de 22", Fructuoso executa a Sonata Fantasia, o $2^{\circ}$ Trio, o Quarteto Simbólico e as Danças Africanas de Villa-Lobos, no Teatro Municipal de São Paulo. Um ano antes, Alban Berg terminava Wozzeck e Milhaud escrevia Saudades do Brasil, depois da experiência como adido cultural da França, no Rio de Janeiro, entre 1917 e 1919, quando Paul Clodel era ministro. É a época das Variações sobre um tema popular, de Vianna, e de sua ida à Europa para uma permanência de quatro anos - período em que acabava de ser criada a 
URSS, sob Stalin; morria Lênin e o Partido Fascista tornava-se único na Itália. Sobre sua ida à Europa, diz ${ }^{35}$ :

Acho que essa audição que tive na Europa, de grandes artistas, contribuiu muito para aprimorar meu gosto. Cito alguns nomes: Koussevitz, que foi o primeiro regente que vi na vida, tocando Le Sacre du Printemps. Quando eu vi aqui o Le Sacre, quantos anos depois, me diziam: "Você viu como é moderno?!" Eu já tinha visto isso na Ópera de Paris, em 1923! (...) O René Bateau, no Pas de Lou; (...); Bruno Walter, na Alemanha, no Messias, de Händel; Furtwängler regente titular da Orquestra Sinfônica de Berlim; Ida Rubinstein...Bailarina e atriz! D’Annunzio escreveu o Batismo de São Sebastião para a Ida Rubinstein. Ele foi ao teatro e a viu dançar. No fim, ele foi na caixa do teatro e disse: “A Sra. vai ser o meu São Sebastião!”. Esse episódio é muito interessante! Ele tinha escrito um poema lírico sobre a vida de São Sebastião, em francês porque ele era bamba no francês. Era um indivíduo riquíssimo! Um gênio italiano! (...) Foi aí que a Ida Rubinstein subiu no meu conceito porque eu não a conhecia ainda mas vi o São Sebastião e, quando assisti, já sabia que o D’Annunzio tinha dito isso. Quem me contou foi uma filha do Alberto Nepomuceno, com quem convivi em Paris. O Ricardo Strauss eu o assisti dirigindo a Orquestra de Berlim, fazendo 50 anos de vida pública. Ele tocou vários concertos: Assim falava Zaratrustra, Morte e Transfiguração, trechos da Salomé e do Cavaleiro da Rosa, Sinfonia Doméstica, o repertório dele. Ouvi o Eugênio Dalberto tocar piano - aluno de Liszt! Émile Sauer, eu o ouvi tocar Berceuse de Chopin, com que delicadeza! (...) Walter Giszeking. Esse eu vi em Berlim. Ele esteve aqui mas eu o vi em Berlim. Arthur Rubinstein, Robert Casadessus, Alfred Cortot, Blanche Selva. (...) Paderewsky, (...), Jorge Enesco, Hubermann - que tocou com o Koussevitz o Concerto em ré maior de Beethoven. Kreisler, Heifetz e Menuhin...

$\mathrm{Na}$ música, as Bodas (1923) de Stravinsky e as primeiras experiências dodecafônicas de Schoenberg (op. 23 e 24). Na Literatura, o Ulisses, de Joyce, e A montanha mágica, de Thomas Mann. No cinema, O Encouraçado Potemkim (1925), de Eisenstein. Em 1928, Fructuoso compõe sua primeira canção, Sonâmbula, sobre poema de Augusto de Lima; ano do Boléro de Ravel, da Ópera do três vinténs, de Brecht-Weill e do nascimento de Stockhausen (Boulez é de 1925). Um ano depois da composição da Sinfonia dos salmos, de Stravinsky, em

\footnotetext{
${ }^{35}$ In CASTRO, 2001, Anexo 3, p. 171.
} 
1931, quando Varèse compôs Ionisation, é inaugurado o Cristo Redentor, no Rio de Janeiro - eleito em 2007 uma das "7 maravilhas do mundo". Gustavo Capanema, amigo de Fructuoso, com quem "carteava"36, fazia parte dos "jovens políticos mineiros, cuja carreira se iniciava na velha oligarquia de seu estado, e tomou outros rumos a partir de 1930". ${ }^{37}$ Em 1929, o colapso da bolsa de Nova lorque provoca grande crise mundial. Até 1930, a base política brasileira foi chamada de política do "Café-com-leite", numa referência à hegemonia dos estados de São Paulo e Minas Gerais que se revezavam no poder, tendo eleito 8 dos 13 presidentes da Primeira República. A partir de 1920, outros grupos oligárquicos descontentes começavam a aparecer, como Rio de Janeiro, Rio Grande do Sul e Bahia, até que, em 1930, uma nova frente se formou com o apoio da oligarquia mineira colocando o gaúcho Getúlio Vargas no poder - a chamada Revolução de 30 , fruto da revolta das oposições à eleição fraudulenta de Júlio Prestes.

Durante este período ocorreram grande revoltas no país, como a Guerra dos Canudos, Revolta da Vacina, Revolta da Chibata, Guerra do Contestado, Revolta dos 18 do Forte de Copacabana, Movimento Tenentista e finalmente a Revolução de 1930, que colocaria este regime abaixo. No campo da economia, foi um período de modernização, com grandes surtos de industrialização, como o ocorrido durante a Primeira Guerra Mundial, porém, a economia continuaria dominada pela cultura do café, até a Quebra da Bolsa de Nova lorque, em 1929. Ocorreram também as primeiras greves, e o crescimento de movimentos anarquistas e comunistas nos grandes centros urbanos do país.Na região da Amazônia, o extrativismo do látex das seringueiras para a produção da borracha experimentou seu auge no período da República Velha. O ciclo da borracha trouxe progresso à região amazônica, especialmente a Manaus e além de trazer divisas para a jovem república brasileira,

\footnotetext{
${ }^{36}$ Cf. Depoimento do MIS: CASTRO, Marcos Câmara de. Fructuoso Vianna, orquestrador do piano. Dissertação de Mestrado apresentada ao Departamento de Música da Escola de Comunicações e Artes da Universidade de São Paulo. Orientador: Prof. Dr. Mario Ficarelli. São Paulo, 2001, Anexo 3 - Depoimento do MIS: - Em fim de Novembro, mais ou menos, voltei do Rio Grande do Sul, isso em 1940, e estava sempre carteando com o Capanema, Ministro da Educação, e pedi a ele um lugar no Rio. Eu mesmo indiquei o lugar, porque soube que estava vago: o de professor de Canto Orfeônico da Escola Técnica Federal. Carteei com o Capanema e ele acabou me nomeando.

${ }^{37}$ FAUSTO, Fausto. História do Brasil. São Paulo, EDUSP-FDE, 1997.
} 
gerou conflitos fronteiriços que deram a posse definitiva do território do Acre para o Brasil $^{38}$.

Guernica, de Picasso, a Sonata para dois pianos e percussão, de Bártok e a morte de Ravel acontecem no mesmo ano (1937) em que a vinda ao Brasil do maestro alemão Hans Joachim Koellreutter movimenta as correntes estético-musicais do país, quando traz as técnicas do expressionismo centro-europeu e das linguagens de Schoenberg e Hindemith. O mestre alemão criou escola (Grupo Música Viva) e provocou reações dos "nacionalistas". Entre seus discípulos mais destacados estão: Krieger, Cozzella, Santoro e Guerra-Peixe. Surge o Grupo Música Nova, com Willy Corrêa, Gilberto Mendes e Rogério Duprat, entre outros, "todos possuidores das mais novas técnicas de composição ${ }^{39 " . ~ U m ~ a n o ~ m a i s ~ t a r d e, ~}$ Fructuoso substituía Guarnieri por dois anos na regência do Coral Paulistano período em que comporia peças vocais: Refrão do Mutum, Sem-fim e Sabiá (esta em duas versões: canto e piano e coro feminino a três vozes) e Chula Paroára (canto e piano).

Em 1942, é criado no país o SENAI (Serviço Nacional de Aprendizagem Industrial), um ano após a criação da Companhia Siderúrgica Nacional, de Volta Redonda (RJ). Na Consolidação das Leis do Trabalho (CLT), de 1943, o termo "pelego" é definido como um "amortecedor de atritos", mesmo ano em que foi criada a União Nacional dos Estudantes (UNE). Após rompimento com o "Eixo", em 1942, por iniciativa do governo brasileiro, em 1944, a Força Expedicionária Brasileira (FEB) vai à "Campanha da Itália". Novamente, em 1946, o PCB goza de efêmera legalidade.

Com o término da Segunda Guerra, continua Mendes, "houve a primeira tentativa de uma nova música brasileira", com Santoro, Guerra-Peixe, Catunda, reunidos em torno de Koellreutter - tentativa que viria a ser sufocada, segundo ele, pela repercussão que teve no país o manifesto Jdanov e pela carta aberta de Camargo Guarnieri, de 1950, uma ano antes da morte de Schoenberg. Eclode o movimento

\footnotetext{
${ }^{38}$ Copyright 1999-2006, http://tiosam.com/

${ }^{39}$ In PAZ (1976), op. cit, p. 393.
} 
Queremista ("Queremos Getúlio!"), contra Eduardo Gomes e Eurico Gaspar Dutra. A expressão "rouba mas faz" é associada a Ademar de Barros, eleito governador de São Paulo em 1947. É criado o FMI, na ONU, em 1946. O General Golbery do Couto e Silva surge em 1949, fazendo parte da Escola Superior de Guerra, onde é elaborada a Doutrina de Segurança Nacional pela "turma da Sorbonne". A Petrobrás é criada em 1953. Getúlio Vargas concede uma gratificação a Vianna como professor da ETF. Após o suicídio de Getúlio, Juscelino Kubitschek é eleito em 1956, tendo como vice João Goulart, e lança seu Plano de Metas, cria o DNOCS (Departamento Nacional de Obras contra as Secas) e a SUDENE (Superintendência para o Desenvolvimento do Nordeste). A partir de um dispositivo da I Constituição de 1891, que atribuía ao Congresso competência para "mudar a capital da União", Juscelino cria a nova Capital da República em Brasília (que passa a ser o novo Distrito Federal, inaugurado em 21 de abril de 1960), com mão-de-obra constituída principalmente de "candangos" (imigrantes nordestinos). Implanta o Nacional Desenvolvimentismo, trazendo para o país empresas como a FNM (que seria absorvida pela Alfa-Romeo, em 1968). O partido Comunista do Brasil (PC do B) é criado em 1961, como uma dissidência do PCB - ano da posse de João Goulart (Jango), tendo como Chefe do Primeiro Gabinete Tancredo Neves, ex-ministro da Justiça do Governo Vargas. Em 1962, o país opta pelo Presidencialismo e segue o Plano Trienal de Celso Furtado, sob Jango. A Volkswagen, a Ford e a GM eram responsáveis por $90 \%$ dos veículos produzidos no país, tornando-o dependente da extensão e conservação das rodovias e do uso dos derivados do petróleo devido ao abandono das ferrovias ${ }^{40}$. O diploma de Fructuoso Vianna, Habilitação em piano pela Escola Superior de Música do Rio de Janeiro, só sairia em 14 de dezembro de 1963. A partir daí, receberia inúmeras condecorações, diplomas e homenagens.

Com a Revolução Militar, é decretado o Al-1 (Ato Institucional), em 9 de janeiro de 1964, e no mesmo ano é criado o SNI (Serviço Nacional de Informação), tendo como idealizador e primeiro chefe o General Golbery. O FGTS (Fundo de Garantia por Tempo de Serviço) dava estabilidade ao trabalhador depois de 10 anos de

\footnotetext{
${ }^{40}$ In FAUSTO, 1993, op.cit.
} 
serviço. O Al-2 extingüia os partidos políticos, reduzindo-os a dois - ARENA (Aliança Renovadora Nacional, que juntou UDN e PSD, à direita) e MDB (Movimento Democrático Brasileiro, que agregou PTB e PSD, à esquerda) - e decretava que as eleições para presidente e vice seriam feitas pelo Congresso em votação nominal e não-secreta. O Al-3 estende a medida para os governos estaduais. É feita nova Constituição em 1967 e Costa e Silva - estranho ao grupo "da Sorbonne" - assume a presidência. É criada a "Frente Ampla" de oposição ao governo militar com Lacerda, Jango e Juscelino, em Montevidéu.

Em 1966, Schaeffer publica o seu "Traité des objets musicaux", propondo o emprego de outras estruturas que não se baseassem nas alturas. (SCHAEFFER, 1966, p.16). Revolução Cultural na China de Mao-Tse-Tung; eleição de Nixon nos EUA; Che Guevara é assassinado na Bolívia, em 1967. Fructuoso presenciou também a campanha fracassada dos EUA no Vietnã (que retirou suas tropas em 1973); o movimento estudantil em 1968, com o slogan "A imaginação no Poder"; a transformação do sistema educativo, a liberação sexual e os movimentos de afirmação da mulher. Grupos que pregavam a luta armada contra o regime militar, como ALN (Aliança Libertadora Nacional), comandada por Marighela, o MR-8 e a VPR (Lamarca) antecipam o fechamento do Congresso através do Al-5. O seqüestro do embaixador americano Elbrick pela ALN e pelo MR-8 ensejam a criação da OBAN (Operação Bandeirante) e do DOI (Destacamento de Operações e Informações) - CODI (Centro de Operações de Defesa Interna) - protagonistas de perseguições, torturas e assassinatos de presos políticos.

Em 1969, Vianna passa a receber uma pensão vitalícia "por sua relevante contribuição à música erudita nacional". Em plena turbulência autoritária, dá seu depoimento ao MIS do Rio, em 1971. A volta da "turma da Sorbonne" materializase com a posse de Ernesto Geisel na presidência, em 1974, ano em que a "Revolução dos Cravos" põe fim à ditatura de Salazar, em Portugal. Dois anos antes do falecimento de Fructuoso Vianna, em 21 de abril de 1976. Época em que Scelsi pratica suas polarizações timbrísticas; Xenakis e Ligeti formulam críticas ao serialismo que engendrariam as experiências da Música Espectral, a partir de 1979. 


\section{CAPÍTULO 2 - O ORIGINAL EMBRIONÁRIO, O "BANAL DISFARÇADO" OU O ORIGINAL EVIDENTE}

Eu acho que a minha música precisa ser analisada com muito pormenor.

(Fructuoso Vianna)

Sólo los individuos existen, si es que existe alguien.

(Borges)

Um compositor, em seus primeiros anos de atividade, pode, no máximo, demonstrar lampejos de seu gênio e talento. "Guru" do modernismo, Mário de Andrade tinha suas preferências pessoais, das quais Fructuoso Vianna só passaria a fazer parte mais tarde. A princípio, antes de reconhecer, em 1931, que Fructuoso alcançava "os domínios da grande composição", Mário viu nesses lampejos de Vianna um "banal disfarçado", que também lhe irritava muito nos franceses (sic). Jovem compositor e pianista virtuoso chegou ao Rio de Janeiro em 1912 para aprimorar-se (como o faria mais tarde na Europa, às suas próprias custas, de 1923 a 1926) e foi intérprete de Villa-Lobos na famosa Semana de 22. Numa carta a Manuel Bandeira, datada de 28 de novembro de 1934, Mário de Andrade $^{41}$ assim se refere a Fructuoso Vianna:

Eu reagi muito a princípio contra a composição dele. Levei um solavanco danado com a Dança de Negros bem feita como o diabo (você sabe que ele é ótimo pianista), mas percebendo na benfeitoria da peça, um banal disfarçado, que em geral é o que me irrita muito nos franceses. Mas acabei entregando os pontos porque de-fato a peça é habilissimamente levada.

"O artista é um ser superior que anda sempre por baixo", dizia Vianna a Mário de Andrade em bilhete ${ }^{42}$ de 1928 , o que, de certa forma, resume sua trajetória como

\footnotetext{
${ }^{41}$ MORAES, Marcos Antonio de (org.). Correspondência - Mário de Andrade \& Manuel Bandeira. São Paulo, EDUSP/IEB, 2000, pp.: 598-599.

${ }^{42}$ Amigo Mario, Um abraço de tamanduá. Envio-Ihe 20 poltronas para você distribuir entre suas alunas mais bonitas, distribuir, porém, entre as do curso particular. Não convém que esse pessoalzinho do Conservatório saiba desde já que o concerto vai redundar numa grande carona. Só à última hora mandarei para o Conservatório a boa nova, que para mim é triste nova. Qual, o
} 
compositor. Não afeito às grandes rodas e ao glamour, preocupado principalmente com o artesanato musical; passou a vida dando recitais de piano e de música de câmara, dando aulas, regendo corais e escrevendo música. "- Com esse ninguém pode!", respondeu com ironia à insistência de Ricardo Cravo Albim, no depoimento do MIS $^{43}$ do Rio de Janeiro, em 1971, sobre Villa-Lobos. Nesse mesmo contexto em que floresceu Villa-Lobos, com o aval do "papa" Mário de Andrade, obscureceu-se Vianna, autor de cristais de música brasileira, ofuscado pelo brilho musical e político do "único" compositor brasileiro. Isso não deve tê-lo incomodado certamente, mas é fato que tantos outros compositores tenham-se ofuscado frente à luz do "maior" deles. O Brasil sempre teve a vocação da grandiloqüência: Itaipu, Transamazônica, a era dos "coronéis", os self-made-men... etc tentaram concretizar este sonho de grandeza. O escritor argentino Jorge Luís Borges descria da democracia por considerá-la um "abuso da estatística"; é igualmente famosa a frase de Nélson Rodrigues de que "toda unanimidade é burra". Fructuoso, como escreveu Drummond, "não fêz barulho em sua travessia terrestre"; deixou apenas um rastro de música apuradíssima".

Este trabalho inicia o resgate da obra de Vianna, começando por suas canções. Trazendo à tona os elementos constituintes de sua linguagem, demonstrando que se trata de um compositor original, de personalidade e idiomático próprios. Longe de ser um compositor menor, merece ocupar seu lugar no panteão dos grandes compositores nacionais, ao lado de Nepomuceno, Oswald, Villa-Lobos, Camargo Guarnieri, Mignone, entre outros. As canções ocupam um espaço considerável em seu opus. Deu especial atenção a essa forma e inspirou-se muito em Schumann e em suas amigas cantoras, com quem fêz turnês pelo país. Seu grande sucesso é, sem dúvida a Toada $n^{\circ}$ 3, de 1930, mas são de igual valia outras até desconhecidas, como Ma Malia por exemplo, de 1938, onde o piano representa uma verdadeira dança de "umbigada", própria do Lundu, e o canto faz peripécias negras em pleno ambiente de recital de câmara. No Madrigal (1955), a voz faz

artista é mesmo um ser superior que anda sempre por baixo! Grato fica o amigo admirado Fructuoso S.P., 23/10/28 - Acervo do IEB.

43 In CASTRO, 2001, op. cit. 
parte da textura polifônica do piano e os tempos são modificados através de quiálteras e mudanças de compasso na tentativa de resgatar os acentos próprios de cada voz, como na polifonia palestriniana. Há também a ... geométrica Canção da Jamaica; o Jazz em Resume of life... Sem qualquer preconceito, Vianna foi nacionalista quando quis e não se furtou a admirar e criar boa música também, como deixa claro em seu depoimento do MIS. Compositor universal, evidentemente original, busca seu lugar - como já queria Edino Krieger ${ }^{44}$ em 1976 -, e este trabalho quer contribuir para isso.

44 "... Se já em 1931 Mário de Andrade lhe reconhecia os méritos, hoje, olhando o punhado de jóias deixadas por esse cinzelador de miniaturas, podemos nós concluir que Fructuoso Vianna tem pela frente toda uma eternidade para crescer ainda mais". KRIEGER, Edino. "Não é preciso crescer para ser grande". Jornal do Brasil, 28 de abril de 1976. Apud CASTRO, Marcos Câmara de. Fructuoso Vianna, orquestrador do piano. Rio de Janeiro, ABM Editorial, 2003, p. 110. 


\section{CAPÍTULO 3 - A ESCRITA VOCAL}

Sua escrita vocal não exige "malabarismos" técnicos do(a) cantor(a), mas elevada sensibilidade e compreensão do texto - tanto o poético quanto o musical. O espaço sonoro utilizado nas 23 peças ${ }^{45}$ ultrapassa a extensão de $13^{\text {a }}$, uma única vez em Sonâmbula, e de $12^{\mathrm{a}}$, em Modinha de Xisto Bahia. O mais usual é a extensão de 7ạ. A nota mais grave utilizada é o SI-2 e a mais aguda o SOL-4, o que torna perfeitamente possível a performance por vozes agudas de soprano e tenor $^{46}$. Suas indicações referem-se principalmente à interpretação: "Sem rigor no sincopado", por exemplo, em Sonâmbula, sugere a plasticidade da síncope brasileira, freqüentemente transformada em tercina; "Devagar e Dolente", na Toada $n^{\circ} 3$, pede ao intérprete uma flexibilidade necessária para traduzir o que Mariz chamou de nochalance do caboclo brasileiro ${ }^{47}$. Com freqüência, a voz caminha com pulsação própria, independente do piano, exigindo plena autonomia rítmica. Algumas onomatopéias são requeridas, à maneira de Janequin (Refrão do Mutum), ou quando transforma palavras em pretexto sonoro (Sem-Fim). A voz falada é sugerida na Chula Paroara (" - Ê vida marvada!") - "falado ad libitum". Em certas canções como Desencanto, o domínio da respiração é fundamental: as frases sucedem-se ofegantes, sem pausas, e exige do intérprete um planejado armazenamento de ar. As ornamentações são simples mas implicam num preparo técnico absoluto, sobretudo na musculatura dorso-abdominal do cantor, e aparecem nas Trovadorescas de maneira particular. Sua escrita rítmica é complexa, com quiálteras e mudanças de compasso, mas não prescinde de fluidez: é possível considerar essas assimetrias como uma tradução contemporânea do contraponto renascentista, que Vianna tanto prezou, com as acentuações do texto preservadas em cada voz. Na maioria das canções, há pontos culminantes que se realizam na região entre MI4 e SOL4, exceto em

\footnotetext{
${ }^{45}$ Dos 18 opus que formam o corpo de suas canções, computadas as Seis canções trovadorescas, completam-se 23 peças para voz e piano.

${ }^{46}$ Consideradas as usuais transposições de uma oitava abaixo, no caso de voz masculina de tenor.

${ }^{47}$ Apud CASTRO, op. cit., p. 64.
} 
Peregrinos de Joazeiro que, possivelmente por razões expressivas, a voz não atinge além do RÉ4, o que the confere um caráter lúgubre, quase processional. A inspiração melódica está presente em toda sua obra, seja vocal, seja instrumental. Chamam a atenção, no entanto, certas construções originais e comoventes como: Desencanto, Partir e Ficar, Bailía, Vilancete, Madrigal, Un ami, Modinha de Xisto Bahia, When we two parted, em que os desenhos melódicos são intensos e carregados de energia expressiva ${ }^{48}$. Motivos e frases sucedem-se através de modulações às vezes para tons distantes, realizadas de maneira eufônica; saltos melódicos de sextas, quartas, quintas e até sétimas soam naturais e sem surpresas, com espontânea fluência. Em sua Ave Maria, o canto adquire um caráter profundamente religioso, diferenciando-se das demais.

\footnotetext{
${ }^{48}$ Entre os elementos musicais, segundo White, a melodia deve ser o mais misterioso: "Sua habilidade em evocar fortes imagens emocionais, em criar notáveis estados mentais de beleza remonta à primitiva ligação da música com a magia". A música de concerto, a religiosa, a nacionalística ou a música cerimonial seriam vestígios da mais primitiva relação do ser humano com a música (In WHITE, 1994).
} 


\section{CAPÍTULO 4 - A ESCRITA PIANÍSTICA}

O piano de Vianna é robusto e elaborado, embora a complexidade da escrita não transpareça numa audição superficial. É preciso penetrá-la para que as sutilezas apareçam. Revelam-se também as vozes corais que ele tanto prezou e explorou. Raras são as passagens que não requerem uma atenção redobrada devido às linhas que se superpõem, cruzam-se e soam independentes na polifonia. Se surge um desenho, um contorno, um motivo, sempre haverá um desenlace, uma fusão, uma variação, um desenvolvimento. Nada no piano de Vianna é gratuito. A esta polifonia são acrescidos os procedimentos típicos do instrumento como 0 cruzamento de mãos, acordes arpejados ou não, pedais à maneira de lasciare vibrare e apojaturas. Como Schumann, Vianna aproveita os arpejos melódicos para ligar notas deixando aparecer melodias independentes. Seus baixos são sempre cuidadosamente elaborados, servindo de sustentação, realizando vozes independentes ou produzindo efeito percussivo, quando intervalos dissonantes são utilizados com proposta timbrística. O padrão é o de criar uma parte pianística independente da voz - com vida própria - que dialoga com o canto, reforçando e sugerindo significados ao texto. Em Sem-Fim, por exemplo, há a ilustração do canto do pássaro. Já na primeira canção, Sonâmbula ${ }^{49}$, de 1928, Vianna demonstra sua vocação de "orquestrador do piano ${ }^{50 "}$ ao transpor para o instrumento uma escrita tipicamente violonística, com seus baixos marcados e os acordes arpejados à maneira de um dedilhado: polegar-indicador-médio/anularindicador que, se transposta para violão, ficaria assim:

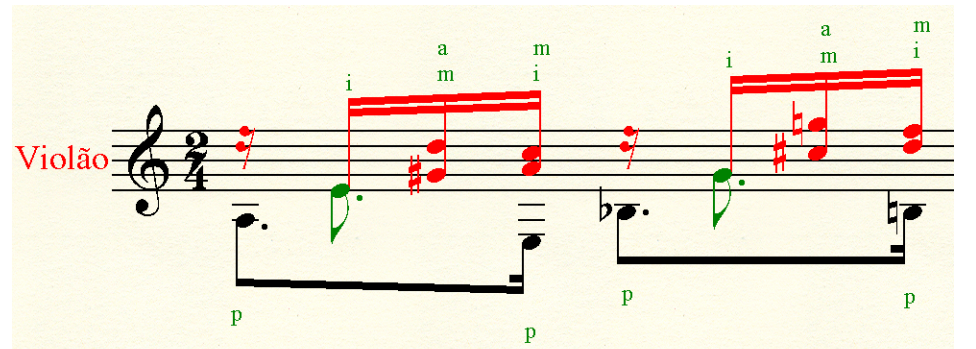

\footnotetext{
${ }^{49}$ A ortografia de todos os textos, títulos e dedicatórias foi atualizada.

${ }^{50}$ Cf. CASTRO, 2003, op. Cit.
} 
Na Toada $n^{\circ}$ 3, de 1930, quem está presente é a viola caipira de cordas duplas em oitavas. A reiteração de oitavas agudas confere uma sonoridade metálica típica das cordas duplas da viola caipira:

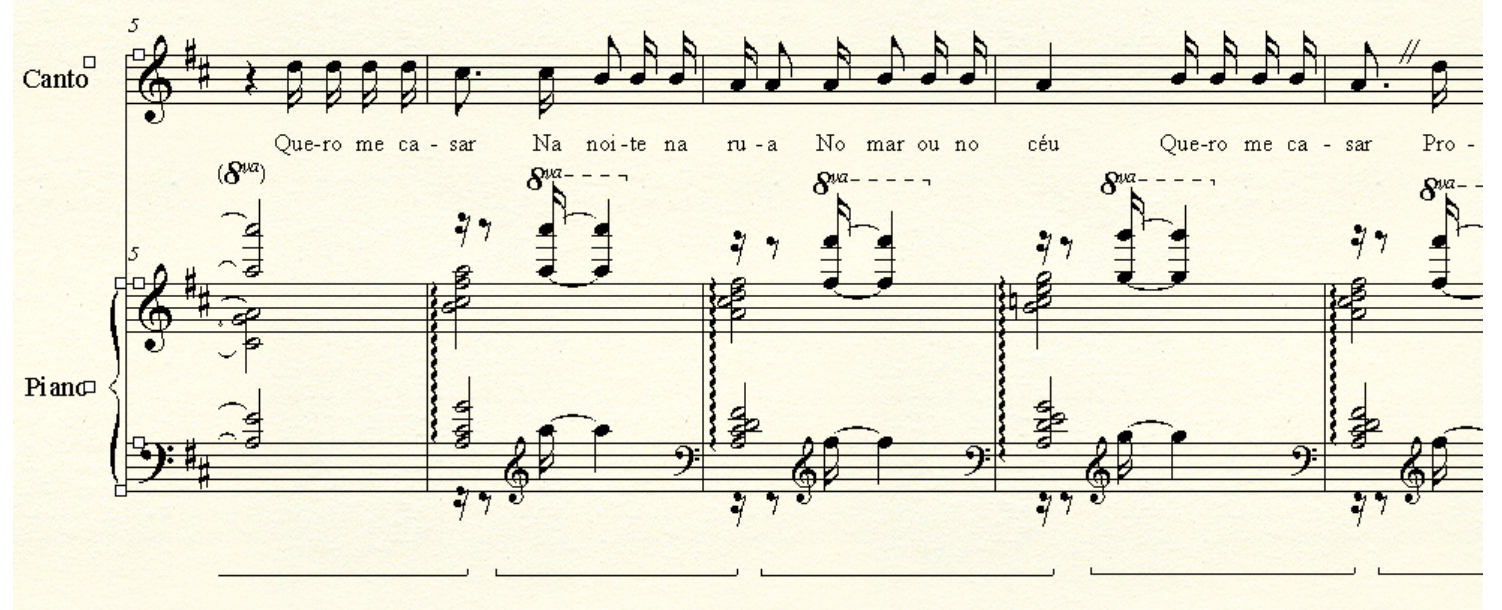

Na canção Ma Malía, ouvem-se as "umbigadas" do Lundu, nos baixos. Em Desencanto, a inspiração vem da modinha e da escrita schumanniana: a parte vocal é inserida num contexto coral a 4 vozes recheada de oitavas, à maneira do op. 39, no IX ("Wehmut"), de Schumann:

Wehmut.

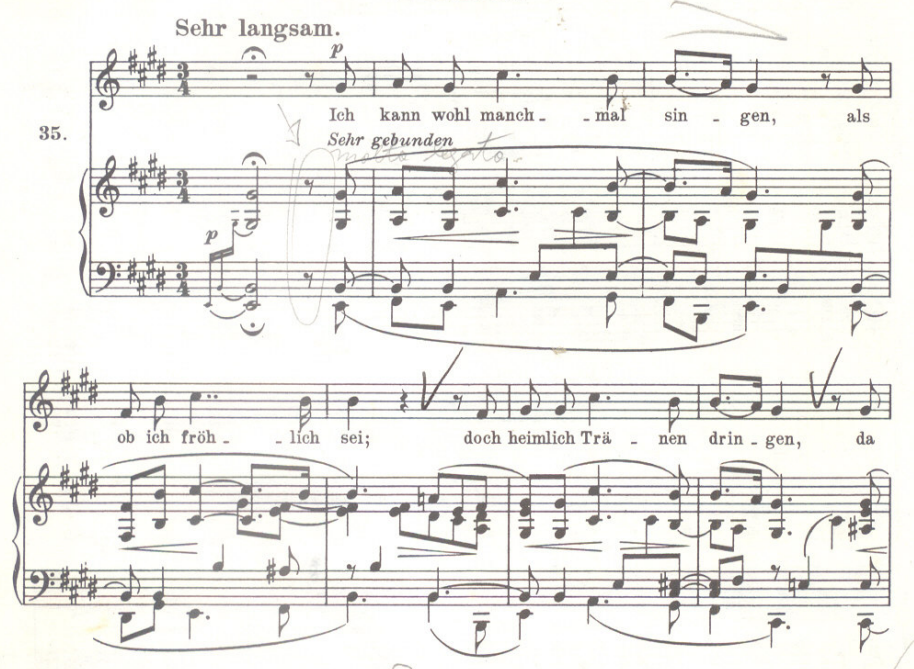


Em Vianna:

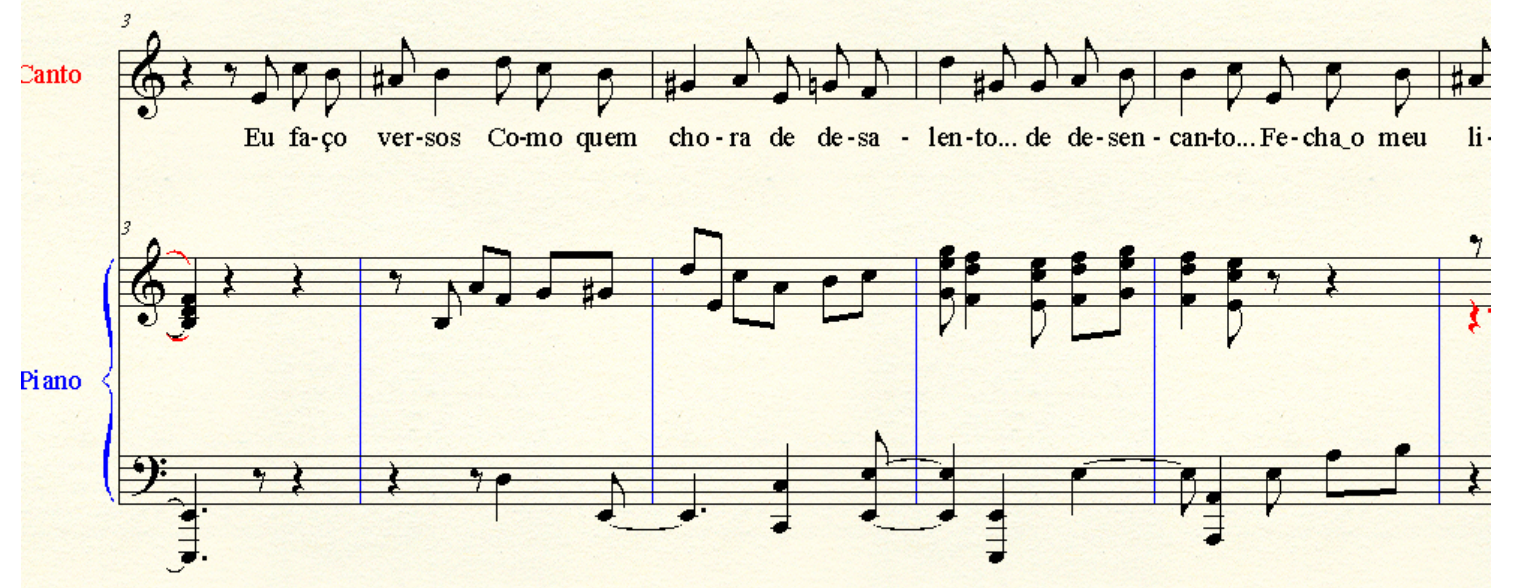

Apesar da clara intenção polifônica, Vianna muitas vezes não separa as direções das hastes das notas na escrita pianística porém tais movimentos não devem ser negligenciados pelo intérprete ${ }^{51}$. Em Peregrinos de Joazeiro trabalha planos distintos entre os baixos em oitavas e acordes no agudo, numa escrita próxima à obra de Brahms, autor que sempre fez parte de seu repertório de recitalista. Em Sabiá, com uma escrita schumaniana, os arpejos têm notas presas ligadas, deixando aparecer melodias em contraponto ${ }^{52}$ e formam um desenho melódico próprio tendo como motivo rítmico a célula $3+3+2$ semicolcheias (em 4/8), sustentada por um baixo simétrico reforçado pelas apojaturas:

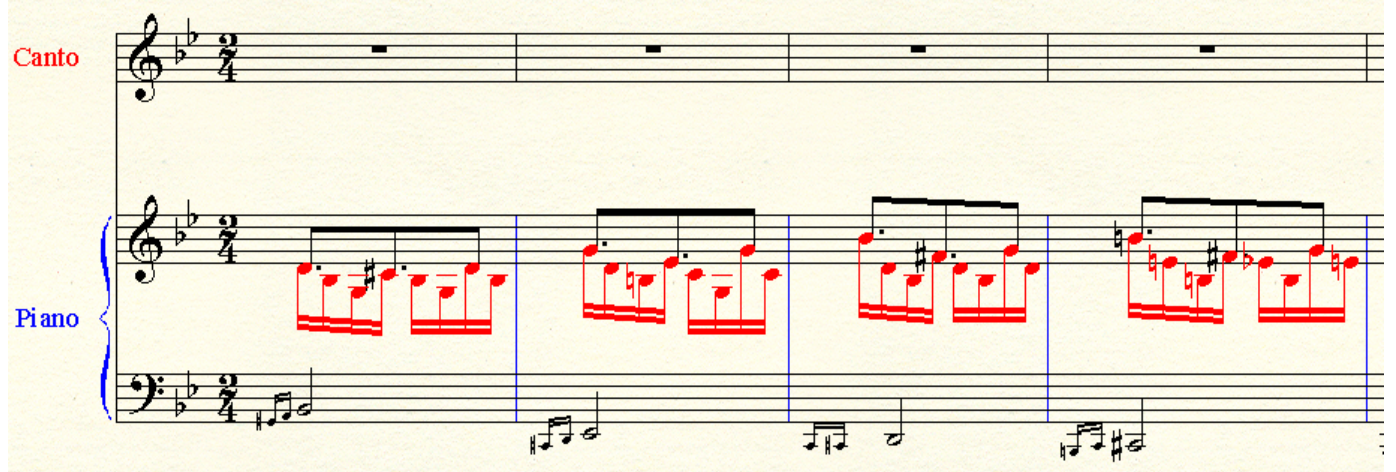

${ }^{51}$ O que não deve ser interpretado como descuido, pois há movimentos nítidos e intencionais das vozes internas: trata-se aqui da clareza e da inteligibilidade da escrita.

52 Tomem-se por exemplo as canções de Schumann: Im wundeschönen Monat Mai e Am leuchtenden Sommermorgen (Dichterliebe, op. 48), entre outras. 
Em Ma Malía, "Lundu de negro velho" também recolhido por Mário de Andrade no seu Ensaio - "canto e dança populares durante o séc. XVIII, introduzidos provavelmente pelos escravos de Angola ${ }^{53 " ~-, ~ c o m ~ u m ~ a c o m p a n h a m e n t o ~ q u e ~}$ lembra as "umbigadas" típicas dessa dança, Vianna abusa dos semitons harmônicos, enfatizando o caráter percussivo. Assim Mário de Andrade ${ }^{54}$ descreve o tema:

(...) Grafei pedaço mais longo da música, embora repetição, pra mostrar a variedade rítmica ocasionada pela prosódia em parte, pela irregularidade do verso mal feito, e em grande parte também pela fantasia que vai se libertando e se manifestando mais, à medida que a peça continua. Com efeito na $1^{1}$ estrofe o ritmo está bem batido e sob o ponto-de-vista brasileiro é simples. Depois se complica extraordinariamente, as síncopas se multiplicam, aparecem antecipações rítmicas, pequenos apressados, rubatos sutis, dificílimos, impossíveis de grafar com exatidão absoluta. $O$ refrão da $2^{\mathrm{a}}$ estrofe repete a música do refrão da primeira e vai sempre assim.

Vianna aceita o desafio rítmico e harmônico deste Lundu e vence com maestria, abusando das dissonâncias, dos contratempos e dando às vezes a sensação de politonalidade quando, em 37 o piano vai para o âmbito de fá sustenido menor, enquanto o canto permanece nas suas reiterações em sol maior:

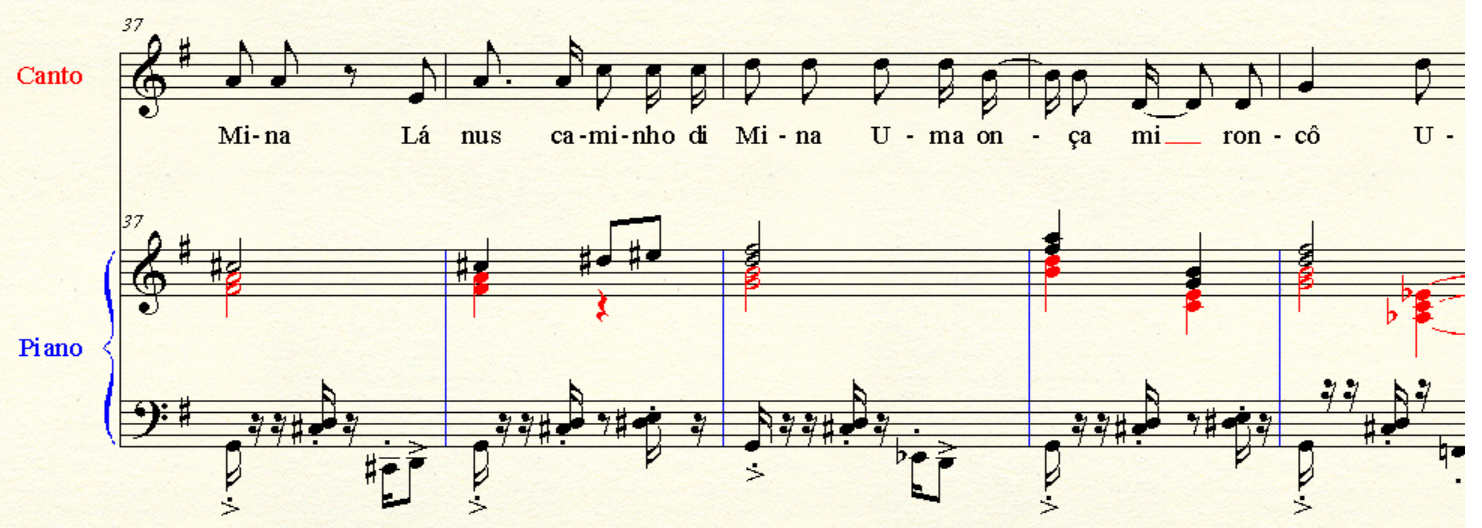

${ }^{53}$ ANDRADE, Mário de; Coordenação: ALVARENGA, Oneyda e TONI, Flávia. Dicionário Musical Brasileiro. São Paulo, IEB/USP - EDUSP, 1989.

${ }^{54}$ ANDRADE, 1972, op. cit., pp.: 143-145. 
Chula Paroára - "Dança portuguesa, usada nas classes proletárias. Compasso de 2/4, andamento afobado. Preferentemente concebida no Modo Maior. Forma estrófica, com refrão instrumental. Os instrumentos useiros na execução da chula são rabeca, guitarras, tambor, ferrinhos e às vezes flauta e clarineta"55. Com um piano construído a partir de acordes bem marcados ao redor dos quais duas linhas se compoem: a do baixo e a de um meio-soprano. Notas longas e estáticas na voz superior e bordaduras de intervalos de segundas, terças e quartas no baixo emolduram a agitada melodia do canto:

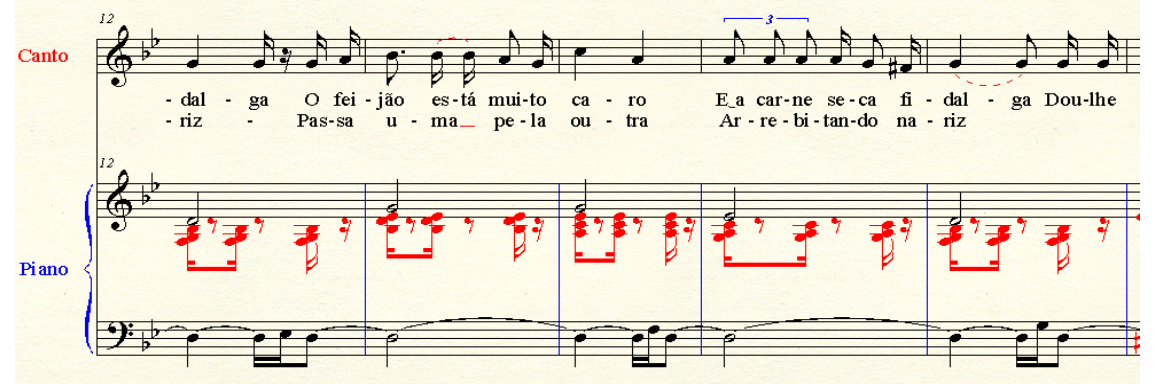

Um interlúdio como "refrão instrumental" evoca os "instrumentos useiros" flauta ou clarinete, no agudo:

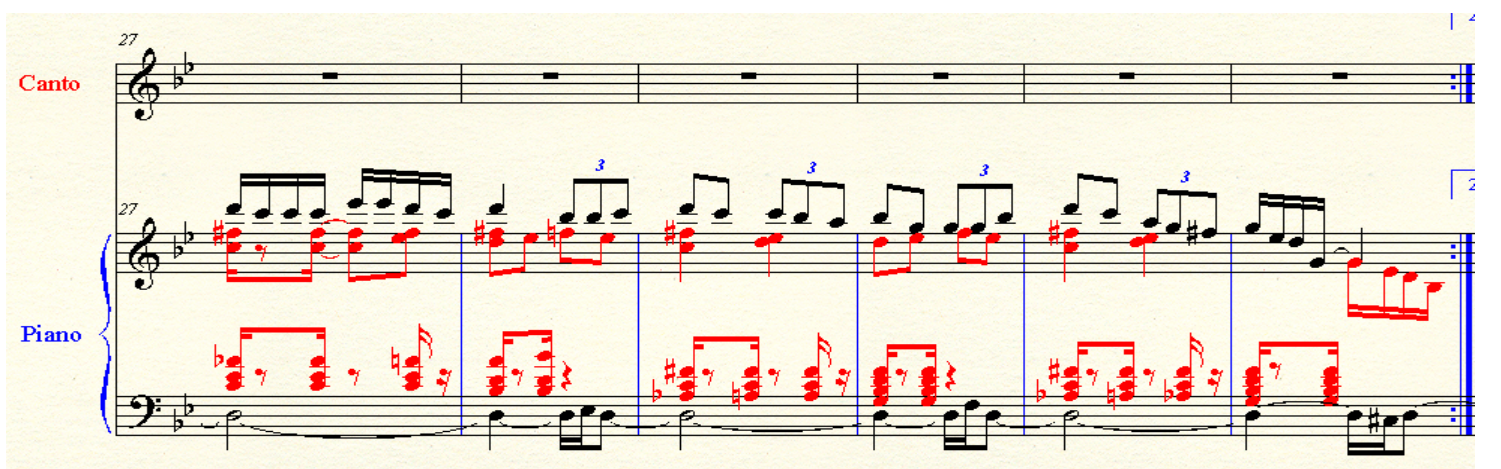

Na Relíquia Apócrifa, uma solene introdução de 8 compassos mistura a escrita coral medieval de quintas, terças, sextas e segundas harmônicas, do Organum livre do século XI, com arpejos e apojaturas. De caráter recitativo, a linha melódica do canto transita entre o modo eólio e o dórico, de acordo com o abaixamento ou não do SI:

${ }^{55}$ ANDRADE, 1989, op. cit., p. 139 


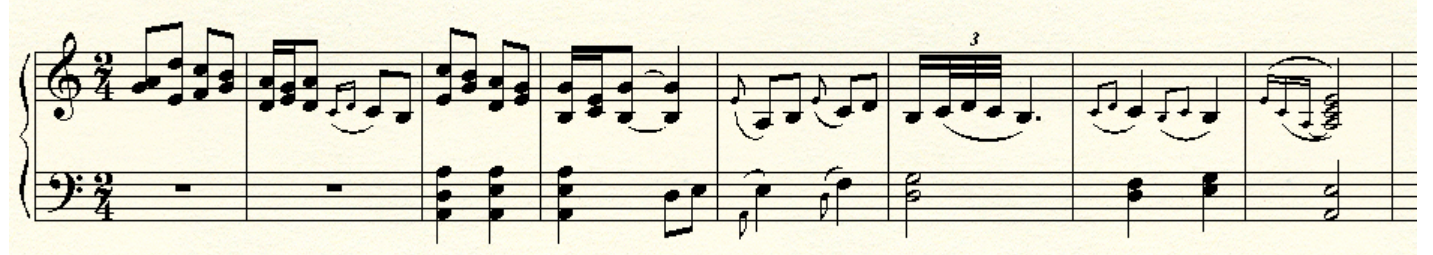

$\mathrm{Na}$ Cantiga dos olhos que choram, o piano recupera o espírito da primeira canção da série, sem no entanto parodiá-la. É o ethos resgatado com arpejos majestosos, movimentos dos baixos em oitavas e às vezes vozes internas dos acordes que se movimentam em cadências com retardos:

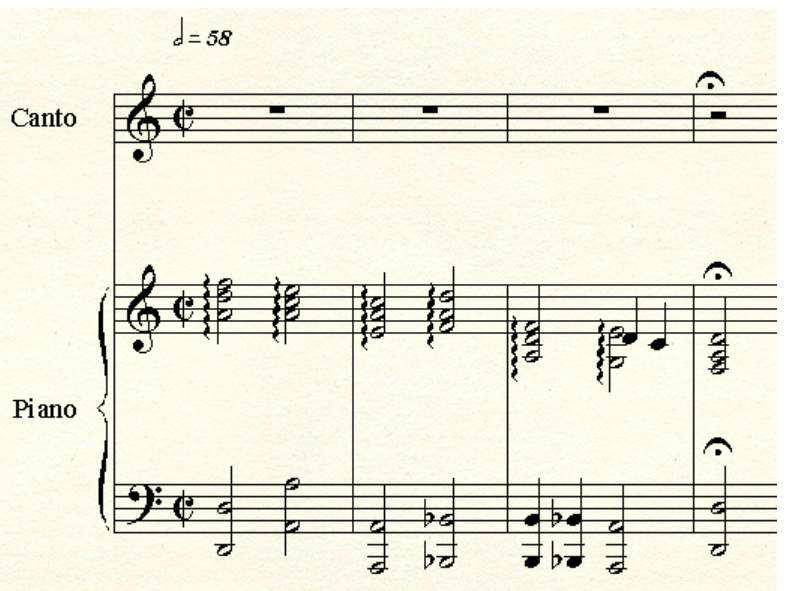

Em Modinha de Xisto Bahia, há um piano que sugere o acompanhamento de um regional, com seus movimentos ágeis nos baixos e arpejos violonísticos na mão direita:

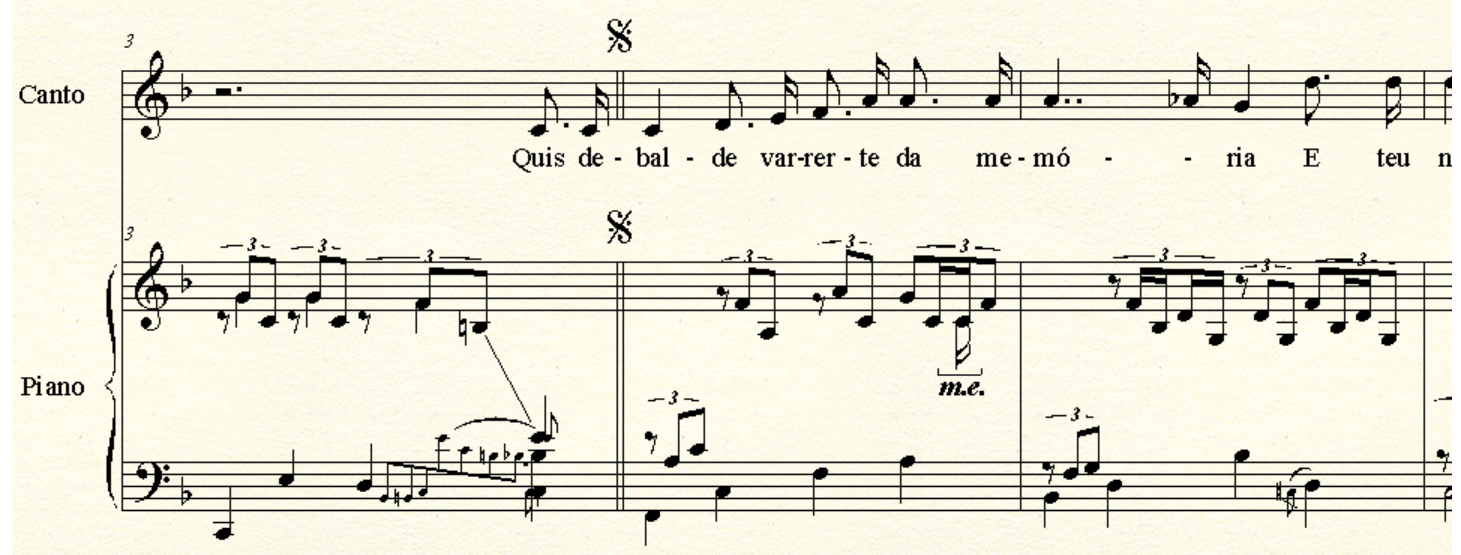




\section{CAPÍTULO 5 - A RELAÇÃO VOZ-PIANO}

O piano, em Vianna, dialoga com o canto de maneira autônoma e não apenas o sustenta. Conhecia e executava em público todo o repertório romântico e o modernismo francês e, por isso, vale o que diz Dieskau ${ }^{56}$ sobre Schumann:

Ici, la voix ne peut plus être peçue en soi. Elle est integrèe dans une nouvelle relation avec l'instrument, le rôle qui lui est dévolu n'est qu'une partie de l'inspiration qui a donné naissance à l'ensemble. (...) Figures musicales (servaeint) alors à "faire pénétrer l'auditeur dans la vie du poème", en particulier sous forme de prélude ou de poslude. Le musicien s'y fait compagnon de route du poète, complète ce que ce dernier ne dit pas ou ne dit que par allusions, mais ne s'arrête pourtant jamais à une simple illustration de l'idée exprimée.

Vianna, como Schumann, "exige donc du chanteur qu'il étudie la partition de piano aussi scrupuleusement que la partie vocale. (...) La voix à elle seule ne constitue pas tout le chant et ne saurait en restituer tout le contenu"57. Assim, as análises do aspecto formal devem levar em conta o "conjunto voz-piano". Às vezes um tema é apresentado por um e reexposto por outro, em efetiva colaboração: voz e piano dialogam e situam-se no contexto das palavras. Por vezes, o piano realiza um discurso independente. Com freqüência é possível considerar a parte do piano como peça independente, como em Sabiá. Em Sem-fim ${ }^{58}$, é o piano que imita o canto do pássaro numa escrita complexa, com arpejos em quiálteras de sete, seguidos de apojaturas, numa região super-aguda:

56 FISCHER-DIESKAU, 1984, pp.17-18: "Aqui a voz não pode mais ser percebida em si mesma. Ela está integrada dentro de uma nova relação com o instrumento, o papel que lhe é atribuído não é senão uma parte da inspiração que deu à luz ao conjunto. (...) Figuras musicais servem então para "fazer o ouvinte penetrar na vida do poema", em particular sob a forma de prelúdio ou de poslúdio. O instrumentista aqui é companheiro de estrada do poeta, completa o que esse ultimo não diz ou só o faz por alusões, mas não se limita jamais a uma simples ilustração da idéia comunicada".

57 idem, ibidem: "Exige então que o cantor estude a partitura do piano tão escrupulosamente quanto a parte vocal. (...) A voz sozinha não constitui todo o canto e não saberá restituir todo o conteúdo".

${ }^{58}$ Cf. CASTRO, 2003, pp. 69-70 - transcrição da análise desta canção por Caldeira Filho. 


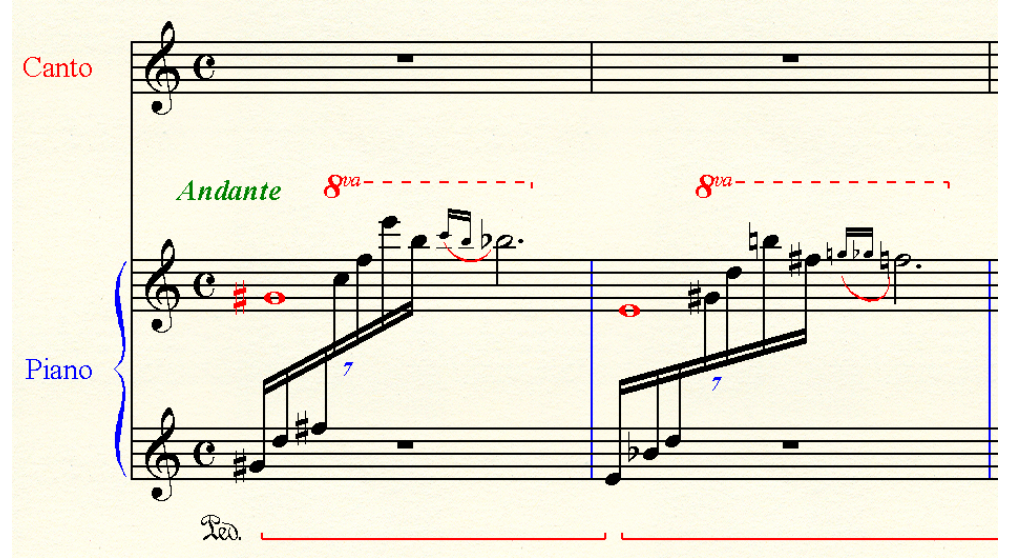

Quando a voz entra, o piano limita-se a um acompanhamento de acordes arpejados sobre um baixo articulado, como nas serenatas de chorões. Ao cantar o nome do pássaro, "Sem-Fim", o piano volta à onomatopéia inicial. Como de hábito, a partir de 16 até 23 , um terceiro campo de tessitura no agudo é visitado em golpes de oitavas em apojaturas, para concluir com o baixo cantante, cromático, sob os arpejos da mão direita. Rica também em cromatismos, a voz traça um perfil que tende para o motivo principal, anunciado pelo piano, de maneira ornamentada, que se resume em:

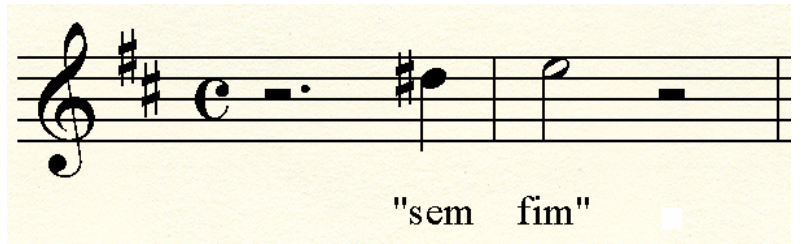

A parte pianística desenvolve-se à maneira de um prelúdio. Raras vezes o instrumento reduz-se a mero acompanhamento com figuras em ostinato, como no Refrão do Mutum. Em Prenda Minha, a densidade da parte pianística diminui com a entrada do canto mas não deixa de ter vida própria e de dialogar com a parte vocal. Em outras, como Chula Paroara ou Ma Malia, o piano é convicentemente percussivo. Às vezes, como em algumas Trovadorescas, voz e piano seguem antifônicas, num jogo de pergunta-e-resposta. Todavia o padrão é a construção elaborada do acompanhamento que sobrevive como acontecimento simultâneo, diretamente relacionado ao canto e com lógica e conclusão próprias. É freqüente o 
retorno à introdução, como conclusão da canção ou a continuação solo do instrumento à guisa de coda instrumental. Vianna incorpora em suas canções o hábito do ponteado entre as estrofes, à maneira das modas de viola e esse procedimento aparece com freqüência: "eu ouvi muita cantiga caipira no interior, moda de viola, isso eu ouvi muito e gosto até hoje"59. Refrão do Mutum ${ }^{60}$ colhido por Mário de Andrade ${ }^{61}$ "da boca de violeiros baianos vindos pelo sertão para São Paulo, gente bruta":

...Improvisavam sempre e tudo, letra e música. Com muito jeito fui vendo se conseguia uma toada que já fosse cantada por outros. Não sabiam de nada. Lhes parecia meio incrível que música fosse repetir coisa já cantada. No meio da autoria monótona, cujo interesse estava só nos versos, um tirou uma moda e fez ela seguir deste refrão. Pelo caráter mais musical do refrão imaginei que era uma coisa tradicional. E era mesmo. Depois pedi, passadas várias cantigas mais, que repetissem a moda da "Mata de $S$. Miguel". Repetiram porém só o refrão. A melodia estrófica já era outra! E das outras cantigas nenhuma não possuía refrão (...).

Melodia popular simples, de caráter descendente, como na Toada ํㅜ 3, também atinge seu ponto culminante quando o sétimo grau é abaixado para entrar no ambiente do modo mixolídio. Acompanhada por um ostinato rítmico que só se modifica harmonicamente:

\footnotetext{
${ }^{59}$ In CASTRO, 2001, Anexo 3, p. 161.

60 Outra coisa que eu queria falar aqui: eu penso, não posso provar, só estou fazendo uma estatística, que fui o compositor que mais aproveitou temas do "Ensaio sobre a Música Brasileira", do Mário de Andrade. Vamos ver, quer ver? Jogos Pueris, Roda das Flores têm dois temas do Mário. Um deles eu já conhecia desde que eu era pequenininho e que minha mãe me cantava. A Canoa (cantarola) esse está no Mário mas o primeiro não (cantarola Roda das Flores). Isso aí eu ouvia minha mãe cantar; isso eu já trazia. (...) Toada no 5 o Mário tem. Vamos contar: aqui tem sete. Eu disse o seguinte: que sou talvez o compositor brasileiro que mais tenha aproveitado temas do livro do Mário. In CASTRO, 2001, op. cit., Anexo III.

${ }^{61}$ In ANDRADE, Mário de. Ensaio sobre a música brasileira. São Paulo, Livraria Martins Editora, 1972: pp: 123-124.
} 


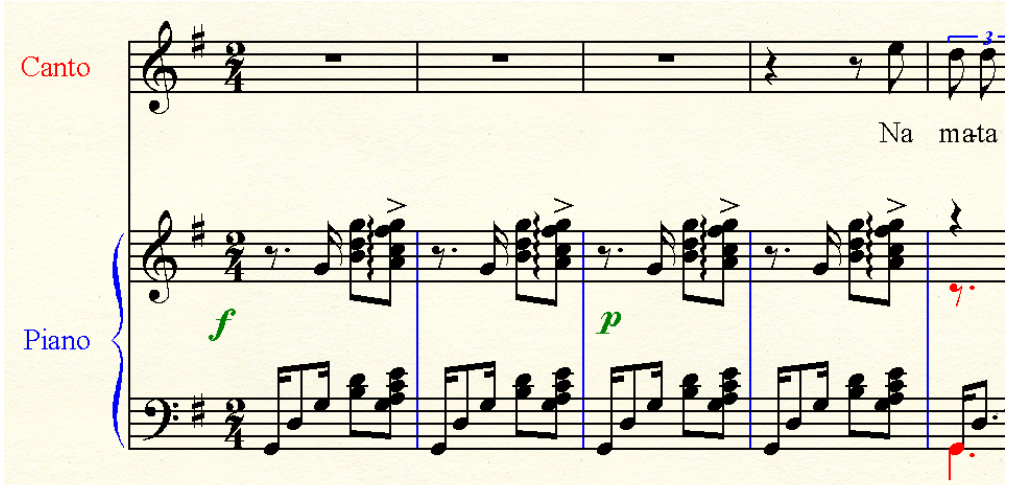

Ou é acrescido de acordes ornamentais no cruzamento das mãos - expediente que Vianna utiliza com freqüência ao visitar simultaneamente diferentes planos de tessitura:

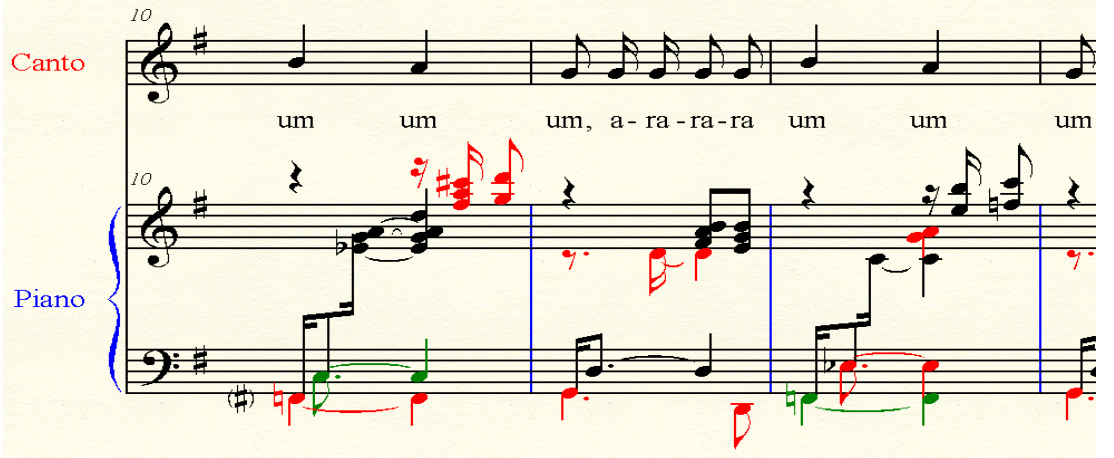

Quando entra o canto, dois recursos de densidade são utilizados, visando o equilíbrio dinâmico entre as partes: os acordes abaixam uma quarta e diminuem em número de notas para:

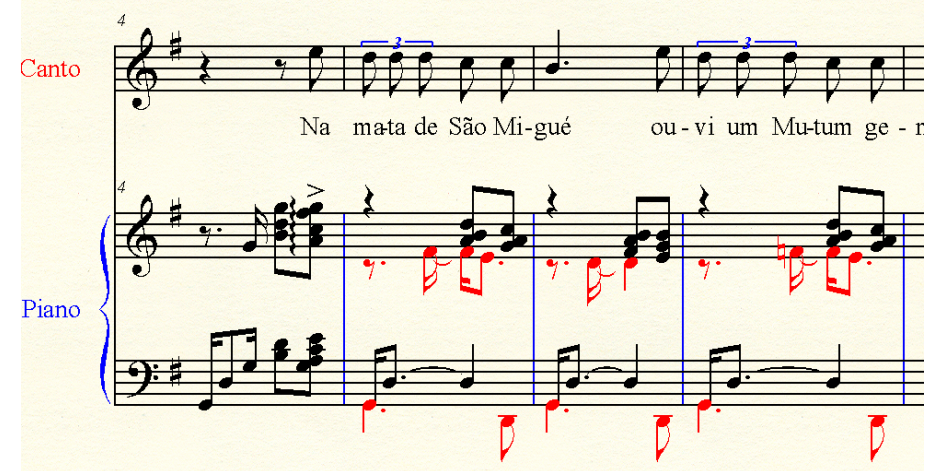


A escrita pianística polifônica nas Trovadorescas mereceu um tratamento especial. Nas seis canções que compoem o ciclo, há uma nítida preocupação em cuidar de cada parte - às vezes duas, às vezes quatro; às vezes cinco, seis... Vocalmente, o compositor exige técnica mas, antes de tudo sensibilidade e acurácia, ao sugerir planos distintos de discursos através da modificação brusca do plano de tessitura, da dinâmica e até de estruturas intervalares. Digno de nota também é a freqüência com que voz e piano fluem em pulsações diferentes, como nas $2^{\underline{a}}$ e $4^{\underline{a}}$ canções. Em Relíquia Apócrifa, a voz vem, seja do agudo ou do grave, e repousa sobre tons médios, SOL e LA, dialogando antifonicamente com o piano que se mantém discreto, como um alaúde.

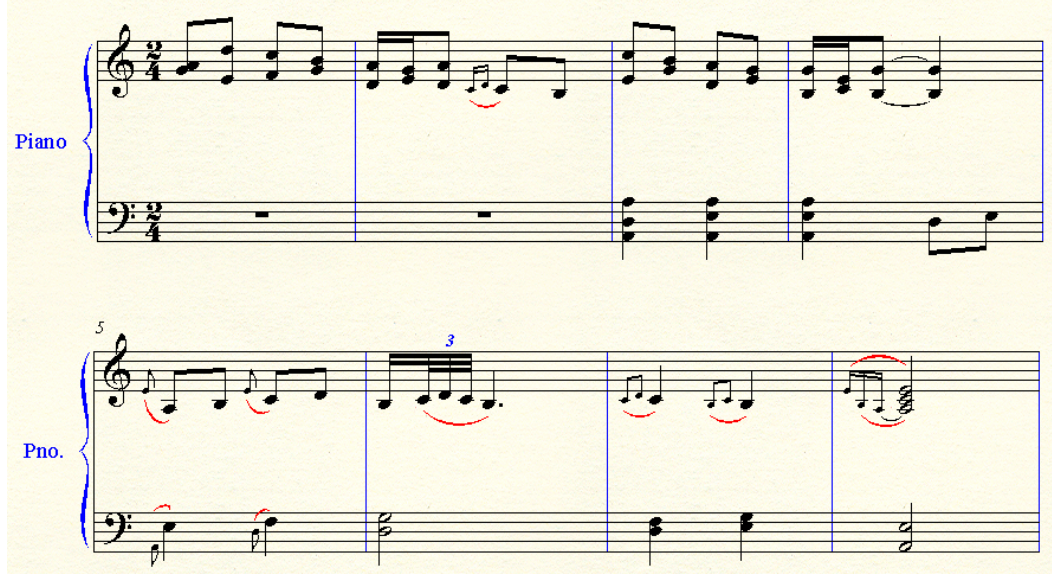

No Cantar Galego, ao estilo arioso do melismático vocativo "Lorilila" é interpolado o recitativo a partir de 19 , acompanhado de um cuidadoso encadeamento harmônico, cerrado, a 4 vozes, de caráter homofônico e rico em dissonâncias que derivam de uma subjacente condução de vozes. Em Partir e Ficar, mais uma vez a sugestão de um alaúde pela escrita polifônica do piano que serve de introdução e coda: 


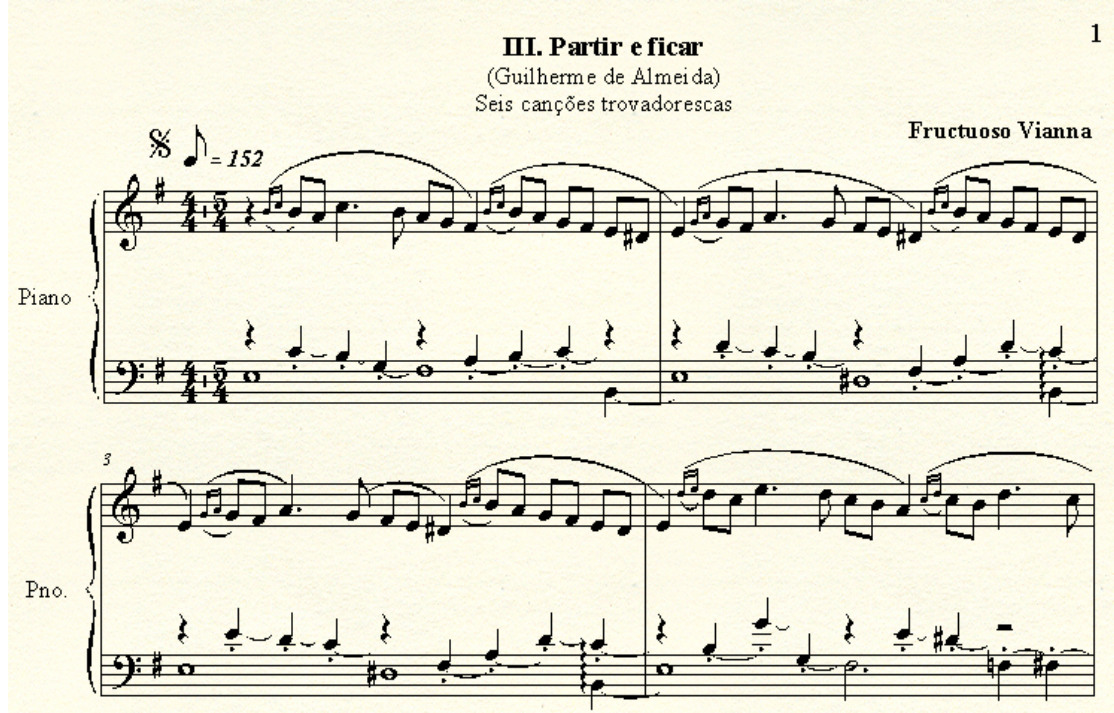

Num procedimento análogo à Cantar Galego, o piano passa a exercer o papel de harmonizador, através de acordes homofônicos, com movimentos de vozes internas e antifonicamente, quando introduz sozinho cada frase do canto, em elisão:

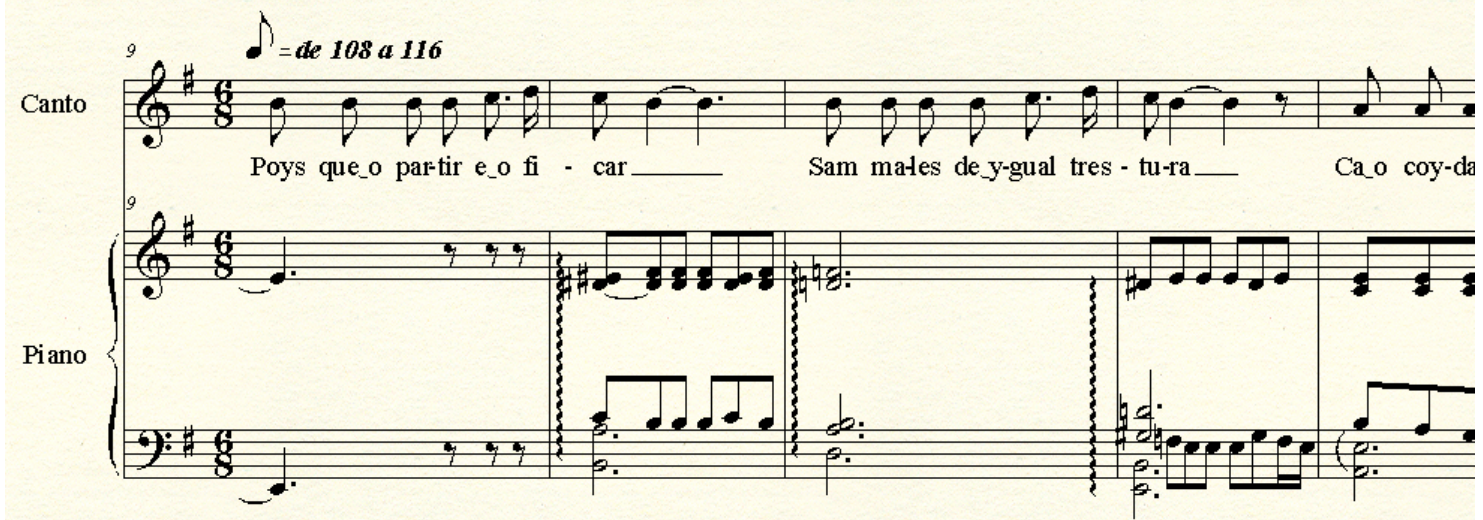


A partir de 21, há brusca diminuição das densidades no piano, prefigurando a reexposição e dando equilíbrio ao retorno:

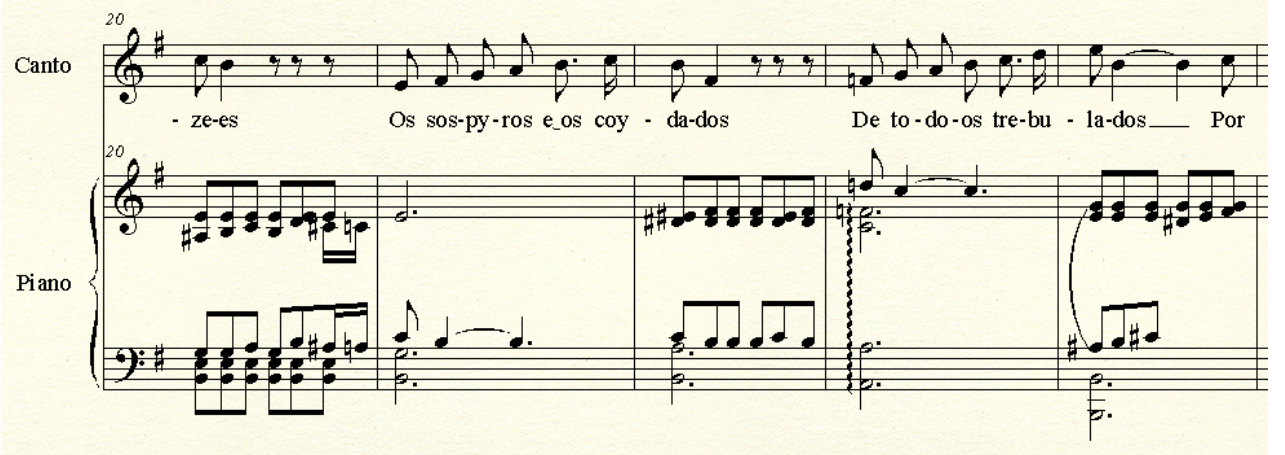

Bailía tem a estruturação preferida de Vianna, uma introdução instrumental para o primeiro período do canto; nova intervenção pianística para a segunda entrada da voz, agora numa extensão maior que inclui notas as mais agudas da obra; de novo a figura de acompanhamento que serve de conclusão, seguida de codetta. Vilancete é uma Barcarola em que a linha vocal realiza a onda que se eleva e se abaixa de acordo com as tendências poéticas do texto, num compasso binário composto (6/8). O piano, quase alheio ao canto, passeia em $3 / 4$ entre oitavas no baixo e acordes arpejados:

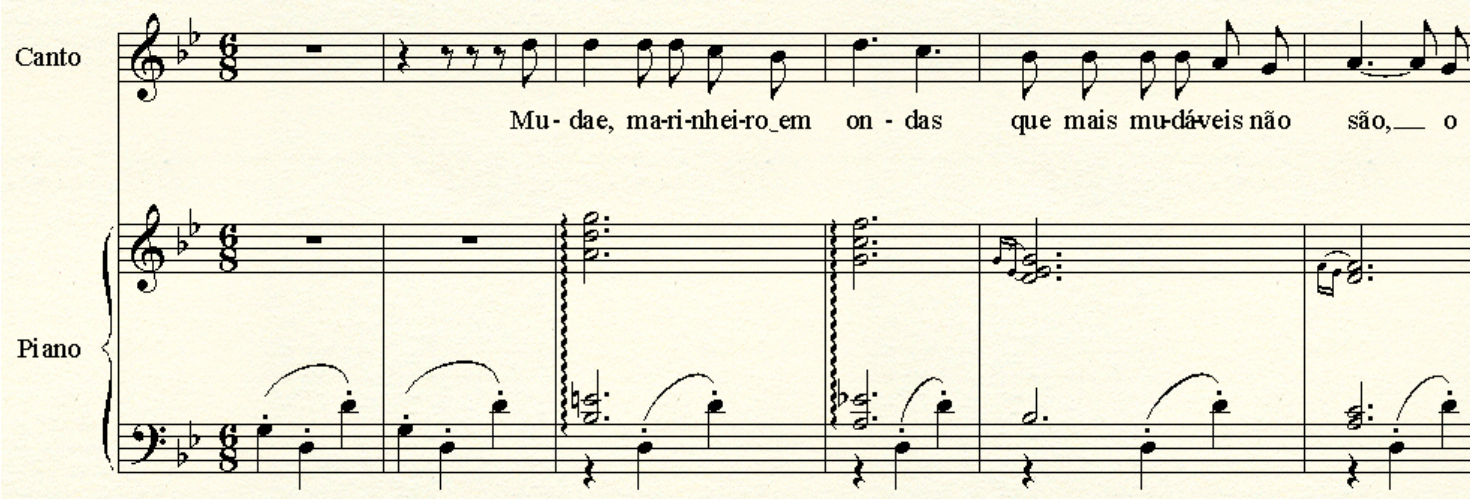


Em certos momentos (comps. 12 - 22), as partes encontram-se no 6/8:

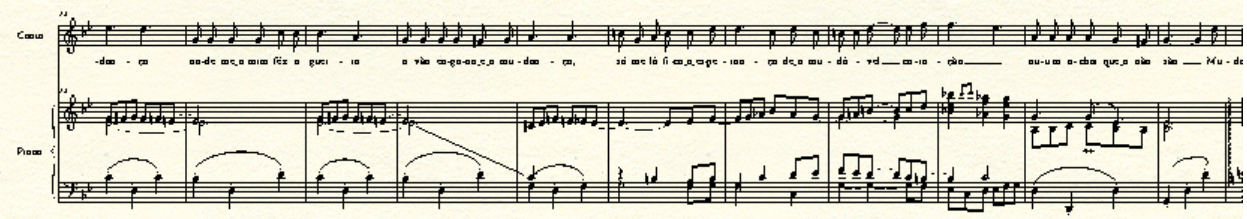

Um refrão configura-se com os versos: Mudae marinheiro em ondas/que mais mudaveis não são/o mudável coração; após o qual sucedem-se períodos (episódios) de 14 compassos cada - o que resulta novamente num rondó do tipo A-B-A-C-A. O segundo episódio é acompanhado por um sofisticado contraponto que substitui os acordes da mão direita do primeiro. Em Madrigal, como que para recuperar a liberdade frasal renascentista, Vianna utiliza os recursos de quiálteras e de mudanças de compasso, permitindo que as partes, tanto do piano como da voz, fluam em "volutas leves, cujas ondulações, nas vozes superpostas, possam se suceder, se unir, se fundir, sem abdicar cada uma de sua marcha individual"62. O piano segue um percurso próprio com a presença da quiáltera de cinco semicolcheias que preenchem um tempo; ora em forma de mordente, ora como arpejo. Partindo de uma escrita contrapontística e transparente, atinge momentos de intensidade expressiva ao arpejar as quiálteras. É o gesto pianístico interferindo na proposta polifônica inicial:

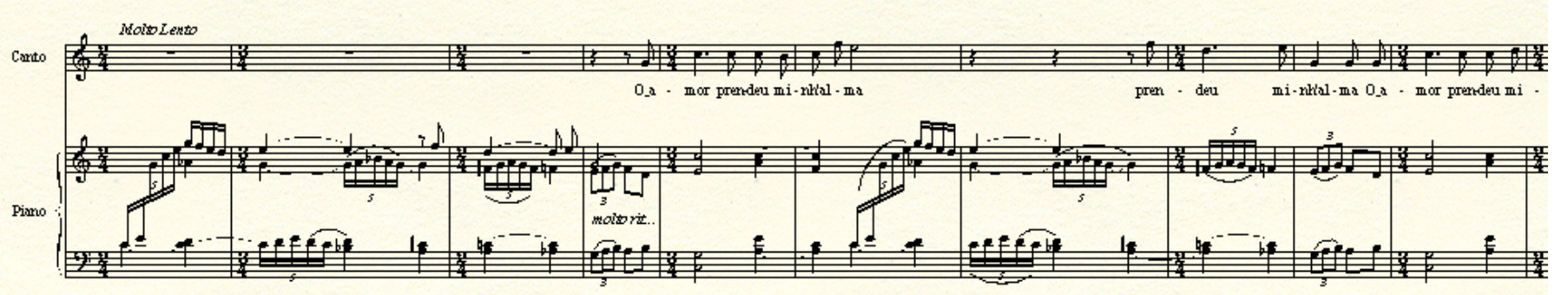

${ }^{62}$ In BRENET, Michel. Palestrina. Paris, Félix Alcan, 1919, p. 151. 
Em momento algum a voz empresta ao piano suas figuras, contentando-se em perfazer seu caminho por frases assimétricas, construindo períodos igualmente fora da quadratura. Em 14 os intervalos da voz expandem-se em arpejos e saltos disjuntos:

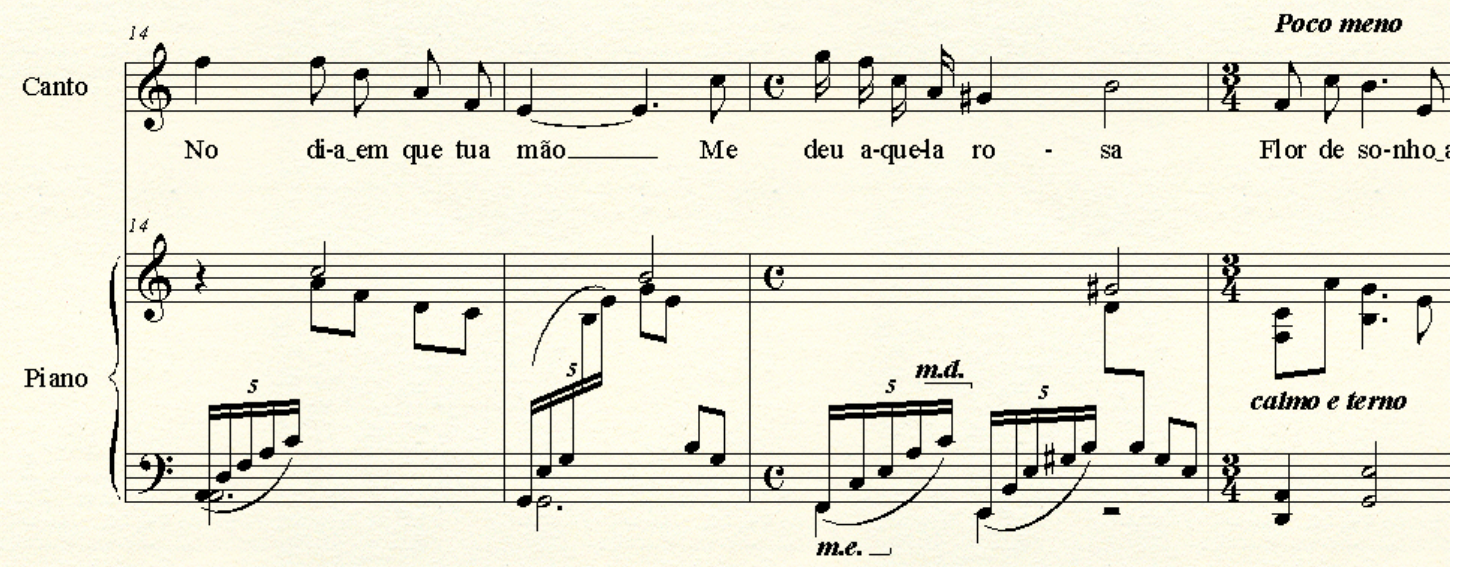

Em 27 novo material é apresentado pela voz, de caráter recitativo, que serve para concluir seu discurso - que acompanha com "Ahs" a coda do piano:

Em Peregrinos de Joazeiro, a associação das oitavas a sinos de catedrais, como em Schumann ${ }^{63}$, é utilizada para ambientar a peregrinação. Acordes provocam ressonâncias, emoldurando a melopéia entoada pela voz:

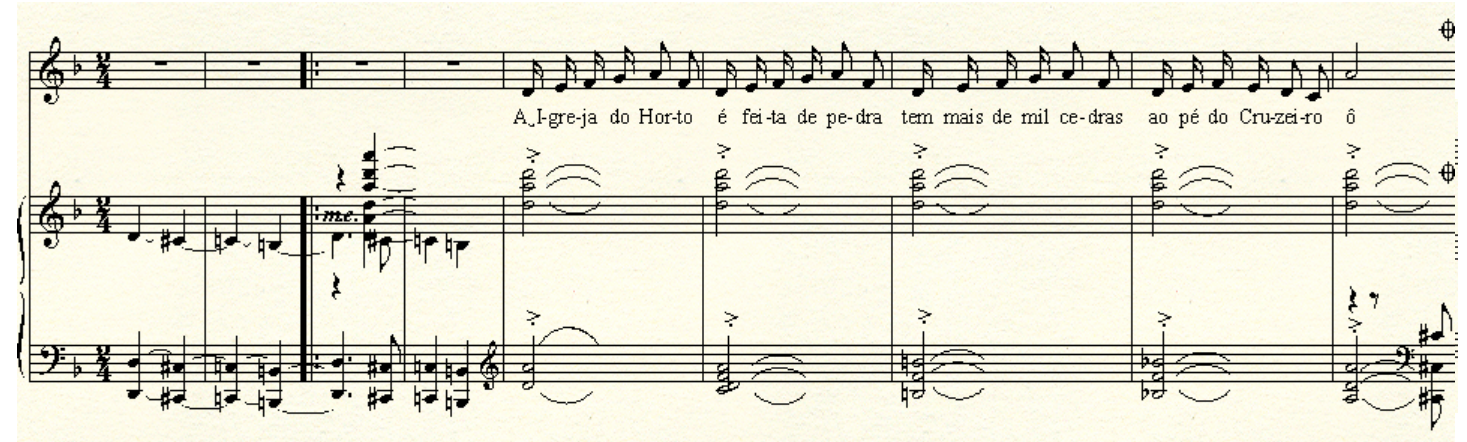

A partir de 11 , contrapontos surgem na parte pianística, e o canto assume 0 contorno de uma cantiga:

${ }^{63}$ Cf. Dichterliebe, op. 48, № VI, "Im Rhein, im heiligen Strome" 


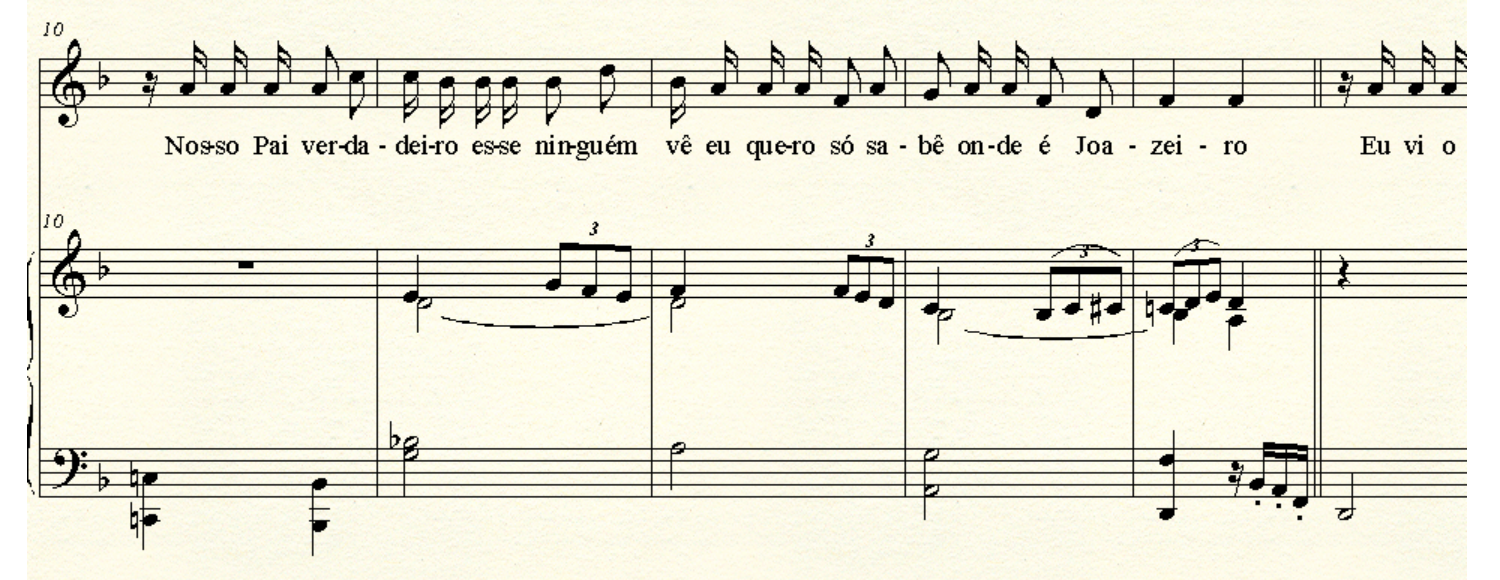

Ao final, sobre o cromatismo das oitavas no baixo são inseridos acordes de quartas superpostas que repousam na tríade de ré menor:

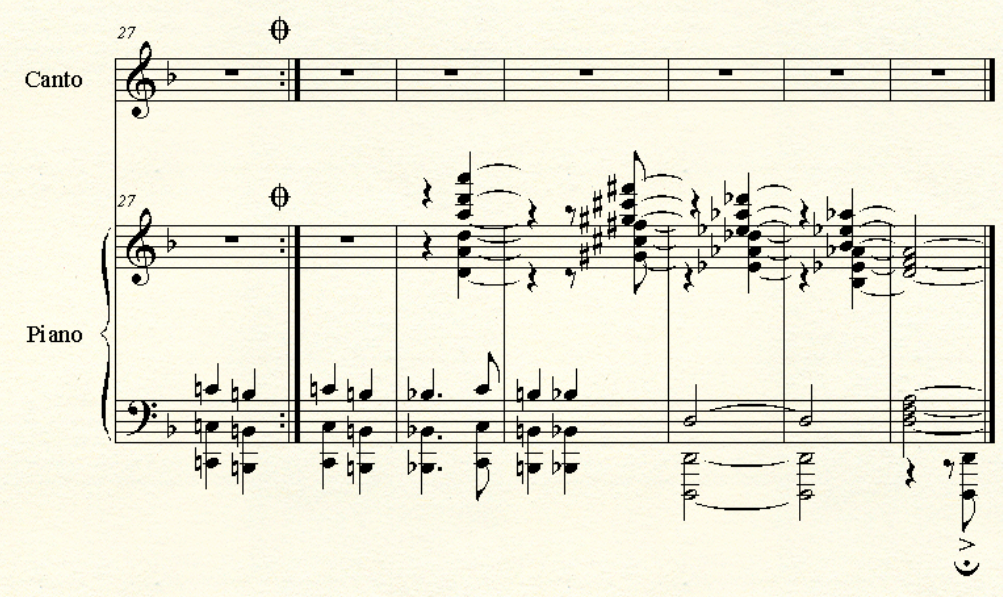

Em Un ami, o salto de sexta do material melódico vocal é antecipado pelo piano que desenvolve discurso próprio escolhendo caminhos paralelos ao canto:

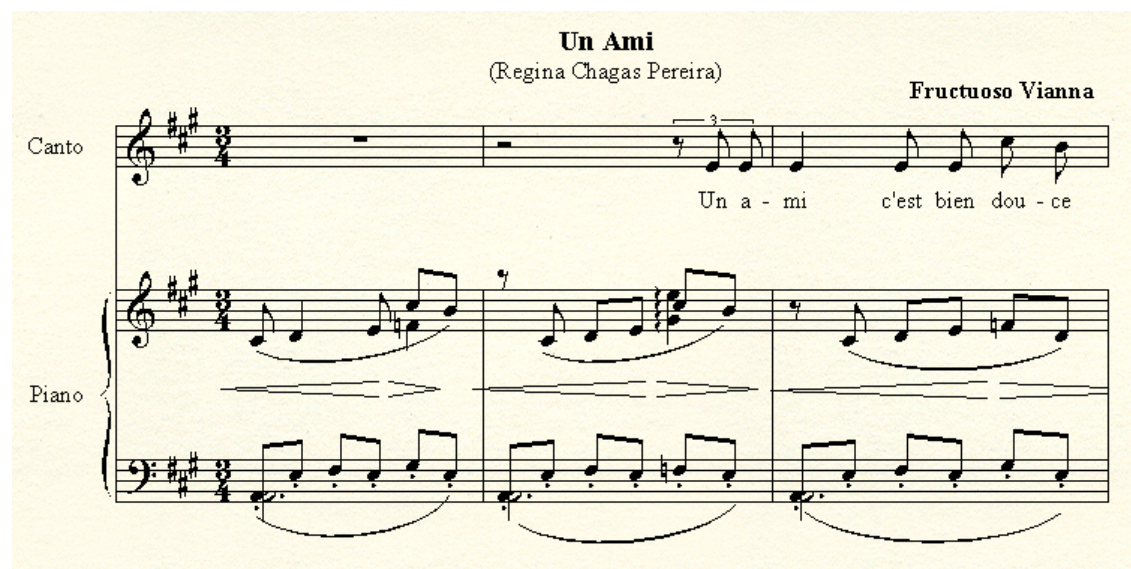


Em 27 um interlúdio instrumental comenta o contorno melódico cantado, mantendo-se o mesmo motivo rítmico do acompanhamento:

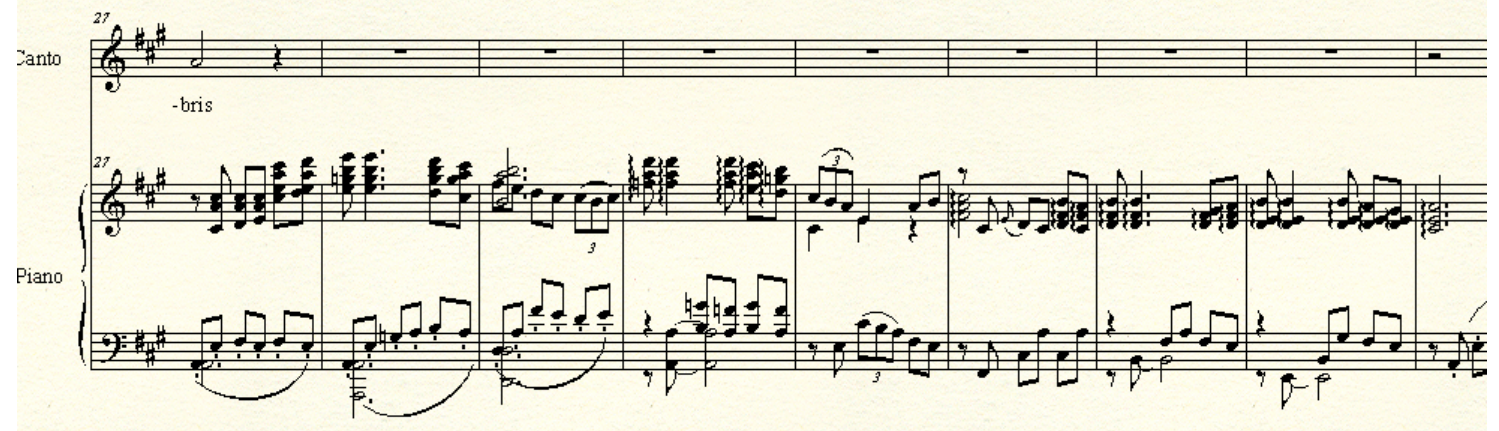




\section{CAPÍTULO 6 - A RELAÇÃO TEXTO-MÚSICA}

Longe de utilizar expedientes óbvios, as ilustrações dos conteúdos semânticos dos textos são realizadas de maneira sutil e detalhista, jamais sacrificando a idéia musical em função de concessões figurativas fáceis. O significado do texto é habilmente representado na condução dos intervalos e das durações. Como diz White ${ }^{64}$ : "It is not always esthetically desirable, then, for a composer to mantain speech rhythm at all costs (but to) take great liberties with the natural rhythm of the words in order to achieve the desired musical results". Em função da quadratura, Vianna dobra os versos "Não sei que mistério tem" e "Nem ela para ninguém", em Sonâmbula, repetindo também o mesmo contorno melódico, para manter a proporção no esquema Antecedente-Conseqüente, num exemplo de submissão do texto à música:

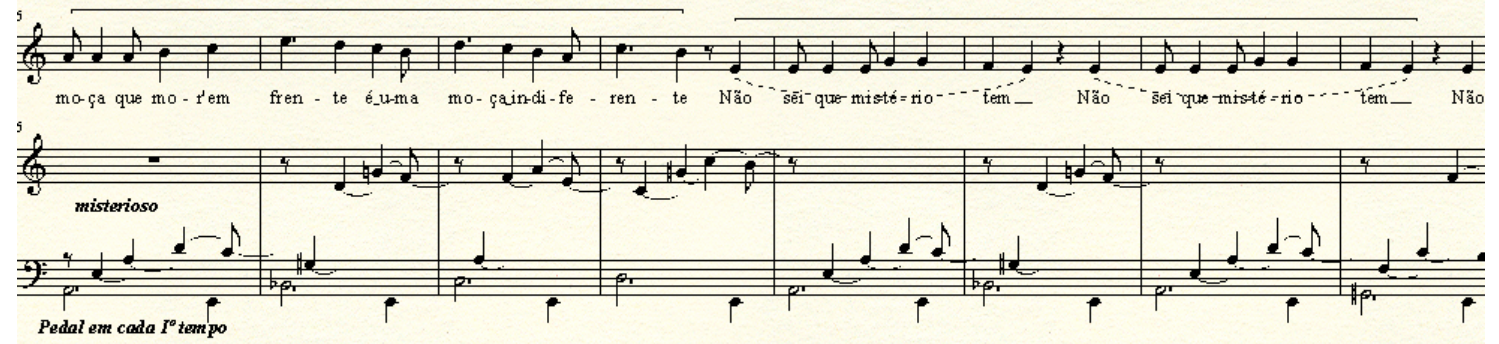

Em Sabiá, a interpretação melancólica do canto do pássaro gera na melodia cantada um cromatismo tortuoso repleto de saltos disjuntos de oitavas, sétimas, sextas menores e quartas diminutas:

${ }^{64}$ In WHITE, 1994, op. cit., p. 128: "Não é sempre desejável esteticamente, então, de um compositor que mantenha o ritmo da fala a todo custo, (mas) que trate o ritmo natural com grande liberdade de maneira a alcançar os resultados musicais desejados". 
Canto $\quad \begin{gathered}\text { Sabiá } \\ \text { (Cássio Motta) }\end{gathered}$

Fructuoso Vianna
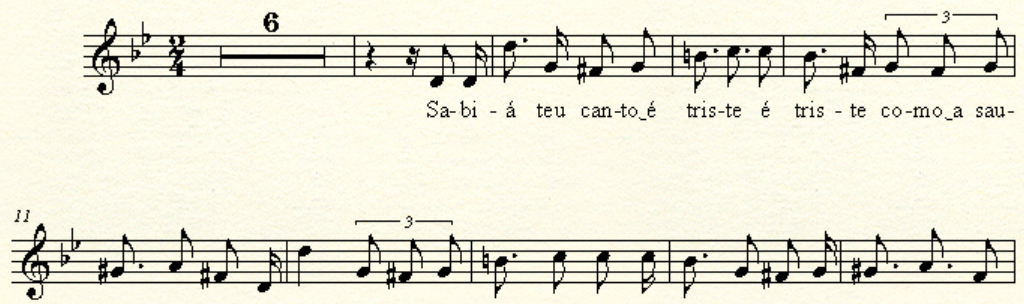

da - de Sa-bi - á nun-ca sor - ris - te nem na tu - a mo-ci - da-de? Por -

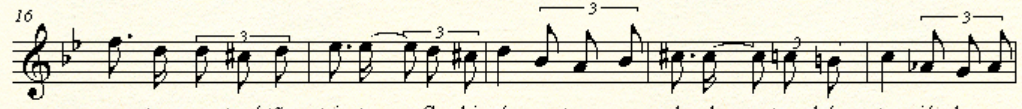

que teu can-to_étão tris-te__ Sa-bi -á con-ta_a ver - da-de__tam-bém tu já des-co-

Esse mesmo cromatismo é verificado em Sem-Fim.

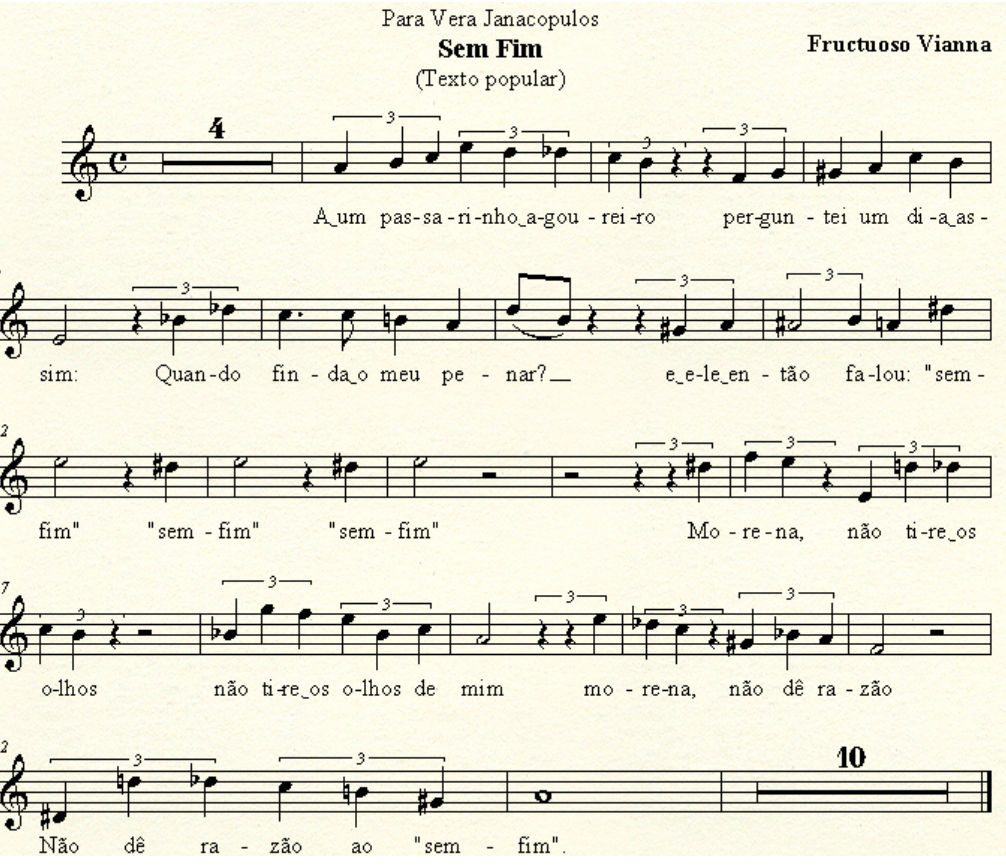


Desencanto incorpora com seu cromatismo e sua seqüência ofegante todo o ethos dramático do poema:

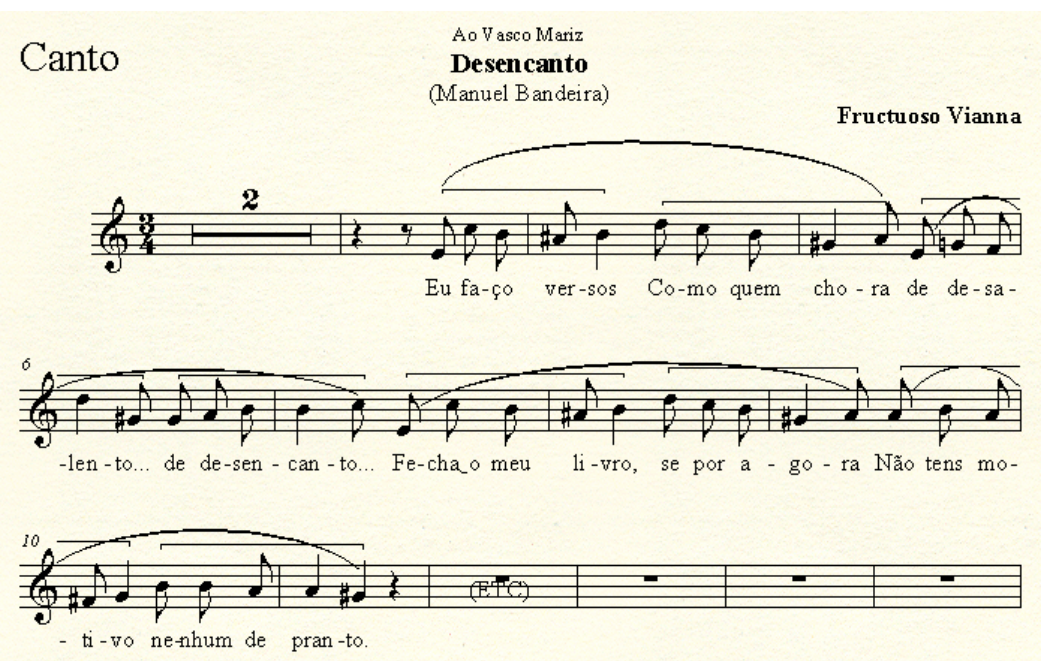

Em Relíquia Apócrifa, o salto melódico ascendente de quarta justa e mordentes escritos conferem uma solenidade apologética da língua portuguesa e seu "predito destino que (...) terá nas terras que ainda estão por ser conquistadas"65:

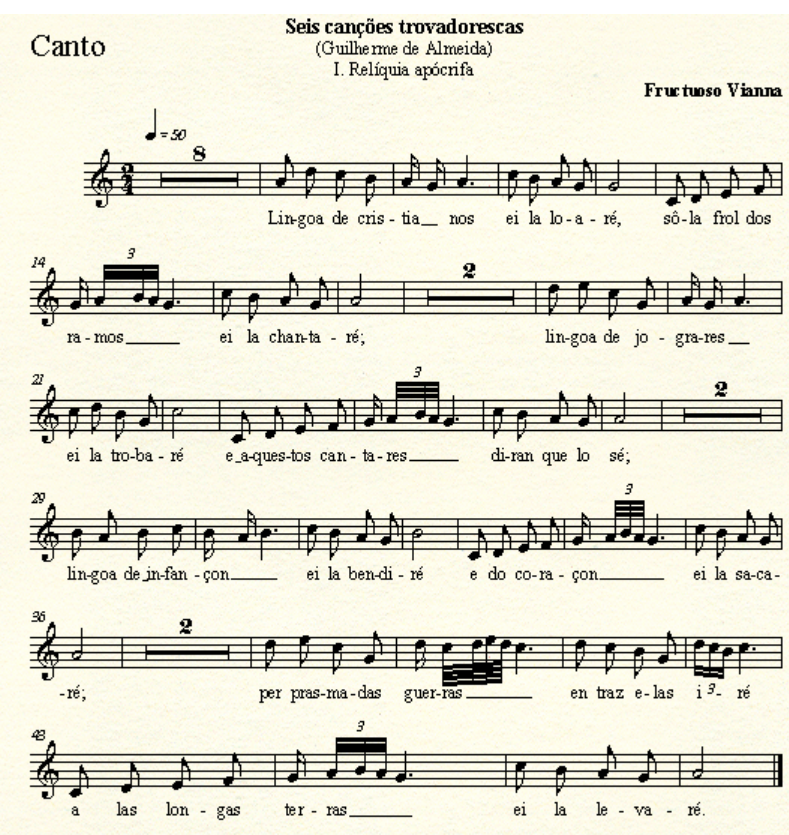

${ }^{65}$ In CASTRO, 2003, p. 86. 
Cantar Galego ${ }^{66}$ interpola um arioso melismático para evocar a musa ("refrão jubilatório", segundo Edmée Brandi ${ }^{67}$ ) com um recitativo que expressa a "morrinha" galega: sentimento tão doloroso quanto a saudade portuguesa e tema constante na poesia galega:

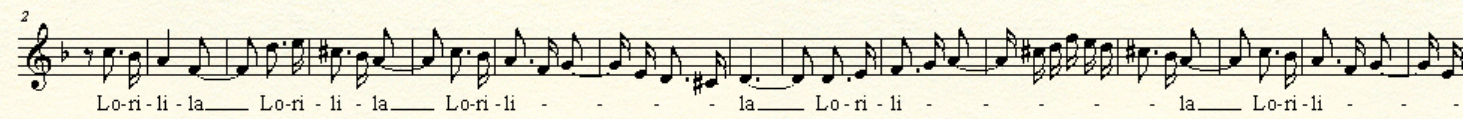

Ao iniciar a narrativa de caráter recitativo, o compositor interpola reminiscências do "refrão jubilatório" com desenho próprio que exige do intérprete uma necessária teatralidade:

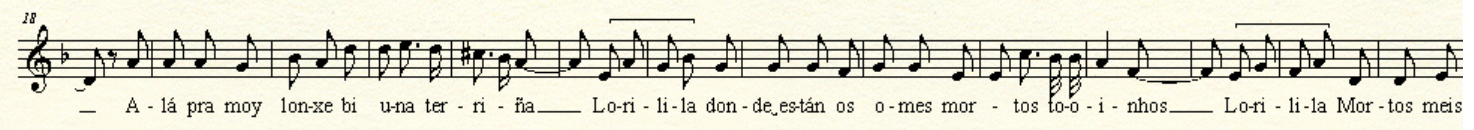

O piano evolui de um ponteado saltitante a grupos de acordes de alaúde com vozes internas bem definidas:

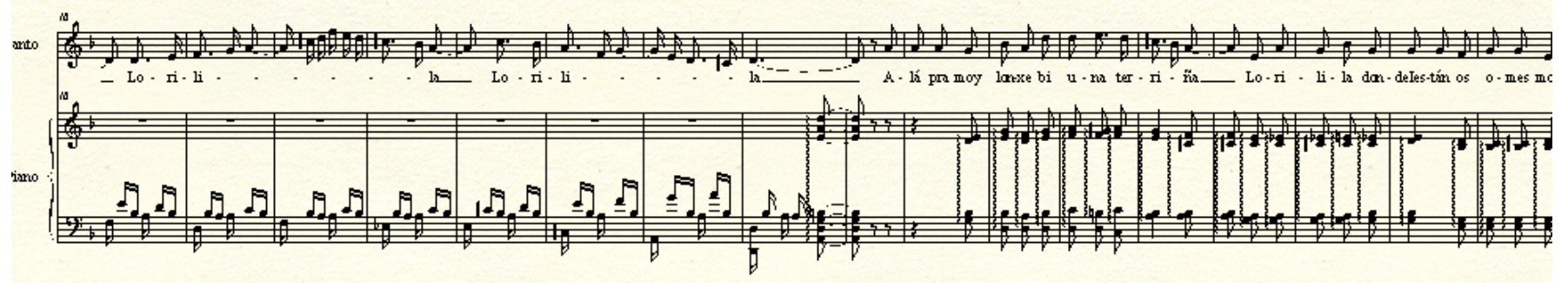

Em Partir e Ficar as frases de dois compassos vão-se bifurcando em suas terminações, em direção ao agudo, para evocar as Barcas que voz hys ao mar e depois, de volta ao solilóquio, retoma a região grave, desenhando um arco descendente:

${ }^{66}$ In ALMEIDA, Guilherme de. Acaso (1924-1928) - Toda Poesia, tomo V, p. 141. Livraria Martins Editora, São Paulo, 1952.

${ }^{67}$ In Castro, 2003, p. 87. 


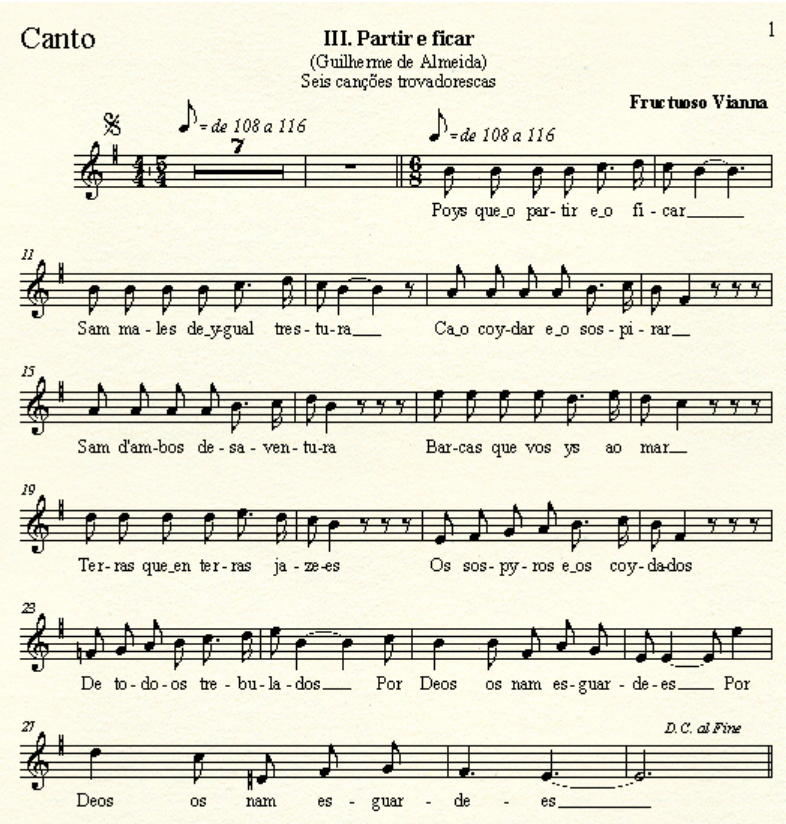

Em Bailía, a celebração do casamento de Portugal com o Novo Mundo é festejada pela ocorrência de "arabescos melódicos no piano que emprestam ao todo um ritmo movimentado e vário"68 que preludía e conclui a canção:
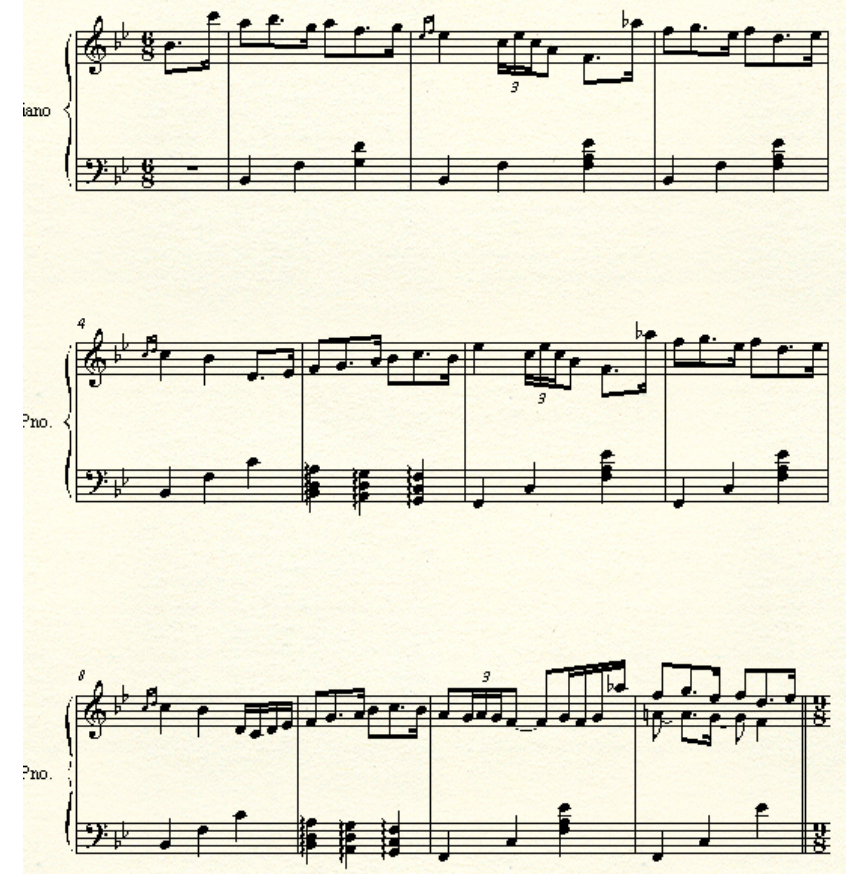

${ }^{68}$ In CASTRO, 2003, op. cit., p. 90. 
A prosódia rege a escrita assimétrica do canto. Períodos de duas frases são os preferidos de Vianna e aqui uma frase solta ao final do segundo período "Das terras novas, das terras longas", deixa o piano concluir com sua própria introdução:

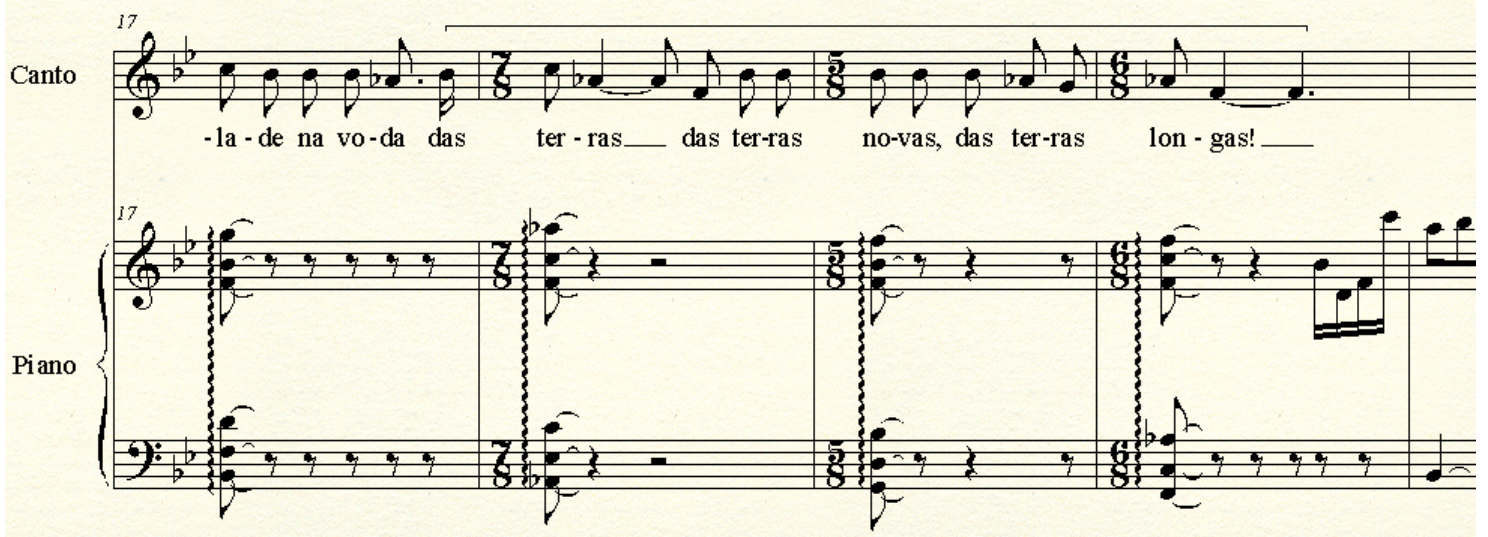

O imperativo "Bailade" de 15 é feito num intervalo de sétima menor ascendente e, em 39 , a ênfase é criada pelo salto de oitava ascendente. Em Vilancete as ondas são visualizadas na escrita vocal em binário composto e o piano com uma figuração de Barcarola faz a ambientação necessária em ternário simples. Às vezes as pulsações se encontram como no acaso das ondulações marítimas de que fala o texto. A partir de 29 , o discurso pianístico reivindica maior autonomia com mordentes que chamam a atenção para uma melodia própria como que evocando a "terra de meus danos".

$\mathrm{Na}$ Toada no 3, o canto transita entre os modos jônico e mixolídio (quando a sétima é abaixada de meio tom) e atinge seu ponto culminante no fá sustenido agudo do compasso 23; e o desenho predominante é:

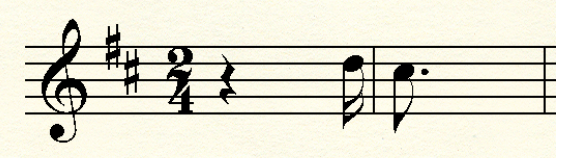


Numa sucessão de graus conjuntos ora descendentes ora ascendentes, toda a construção das frases se dá a partir desse motivo gerador. Em 13, ocorre o primeiro salto disjunto, depois que a síncopa é diluída em tercina ${ }^{69}$, concluindo a segunda seção. Em C , depois do refrão instrumental, o desenho reaparece, criado de forma inversa (de baixo para cima), como uma variação do primeiro período, enfatizando a repetição do conteúdo do poema, repetindo o jargão "Quero me casar". Em 33 , "Mais devagar", conclui com um salto de oitava ascendente, reiterando a idéia da necessidade de se casar: "...que o amor não pode esperar". Em Sabiá, o canto pulsa num binário simples e alterna saltos de oitava e quinta com movimentos cromáticos, num contorno melancólico, em tom de sol menor. Em 17, a melodia sobe uma terça, transpondo-se para a relativa maior si bemol e vai descendo cromaticamente para o tom menor original em $25 \mathrm{e}$ o 8/8 do piano é reforçado com acordes na região central de sua extensão. Para concluir, os acordes ecoados no agudo, ampliando os campos de tessitura, valorizam a repetição do último verso: "Se cantando eu soluçar, Sabiá, é de alegria" - expediente que Vianna utiliza com freqüência preenchendo a extensão com acordes no agudo, aumentando a densidade do discurso, conferindo-lhe maior tensão emotiva: são "gritos" que se ouvem como um recurso expressivo sugerindo um desespero contido, bem conforme a "timidez efusiva condicionada à delicadeza de sentimentos", de que falou Ayres de Andrade ${ }^{70}$. Em Chula Paroára, como já havia feito o uso da voz falada nas Sete miniaturas sobre temas brasileiros, de 1932, também há sugestão de um grito final: " - Ê vida marvada!", enfatizando o processo dos nordestinos que vão explorar borracha na Amazônia (paroaras) e "depois de irem gastar na terra deles o dinheiro ganho na borracha, voltam de novos pros seringais". ${ }^{71}$

\footnotetext{
69 "(...) Ao topar com a noiva, ficou todo sensualizado, num dengue caricioso! Abandonou as células rítmicas em que vinha e dançou suavíssimo numa valsante tercina". Mario de Andrade, apud CASTRO, 2003, op. cit., p. 64.

${ }_{70}^{7}$ APUD CASTRO, 2003, op. cit., p. 51.

${ }^{71}$ In ANDRADE, 1972, op. cit., p. 142.
} 


\section{CAPÍTULO 7 - AS FORMAS MUSICAIS}

Toutefois, aucune tentative académique d'établir des lois permanentes n'a jamais aidé ou gené la progression du travail en art.

(Ravel)

J'ai moins peur, en musique, de l'élément charme, par lui (Schönberg) évité jusqu'à l'ascétisme, jusqu'au martyre.

(idem)

Fructuoso não faz questão de simetria e suas frases e períodos raramente seguem as proporções binárias clássicas. Às vezes uma conclusão precipita-se; em outras, prolonga-se inesperadamente. A forma ternária clássica (A-B-A) aparece com freqüência, sendo $A$ um prelúdio pianístico que é reexposto após a apresentação do canto que é acompanhado por variações e desenvolvimentos do material pianístico, adequado às exigências da voz cantada. Muitas vezes o acontecimento pianístico é intercalado à maneira de um refrão, como um ponteado de repentistas que dividem diferentes episódios cantados, à maneira de um Rondó. Cada canção engendra sua própria forma e Vianna - como Ravel - não tem medo do charme, do "erro", do inusitado ou do inesperado; seguindo caminhos próprios conforme sua inspiração, sugerindo e aproveitando os elementos no desenlace. Resume of life, por exemplo, está inserida numa atmosfera jazzística e o piano - que a princípio parece apenas amparar o canto com acordes improvisados - desenvolve uma figura rítmica de semínima duplamente pontuada, seguida de semicolcheia, que vai adquirindo importância no discurso, é elaborada e floresce como motivo temático intrínseco à obra. Os motivos vocais sucedem-se independentes e sua variedade de contornos lembra as grandes melodias do Jazz, como Stardust, Skylark (Carmichael-Parish), entre outras, que, do mesmo modo, apresentam frases auto-suficientes. Ocorre também que voz e piano desenvolvam-se ciclicamente através de motivos ou breves contornos que são sujeitos a variações e desenvolvimentos. Uma figura de acompanhamento pode servir de material para variações e desenvolvimentos, 
onde aspectos como textura, densidade e contornos são os principais parâmetros. Vianna não quis ser vanguarda mas não estava desinformado sobre a produção de sua época, a ponto de fazer uso de procedimentos modernos dentro de sua linguagem pessoal, sem descaracterizar-se.

Na Sonâmbula, a introdução tem seis compassos e serve de interlúdio à maneira de um refrão - que se interpola às duas estrofes da voz cantada - e finalmente como poslúdio com coda. Trata-se de uma progressão harmônica que evolui de Lá menor, cromaticamente, guiada pelo baixo, percorrendo uma sexta ascendente e descendo sobre o Mi grave inicial, num acorde de dominante-menor-com-sétima da tônica relativa - o que dá um efeito de ressonância violonística, que lembra as várias cordas vibrando ao mesmo tempo. Quando a voz entra, o desenho violonístico modifica-se, sem perder suas características timbrísticas e preserva, na escrita pianística, a indicação das cordas violonísticas que continuam a vibrar, através de ligaduras à maneira de lasciare vibrare:

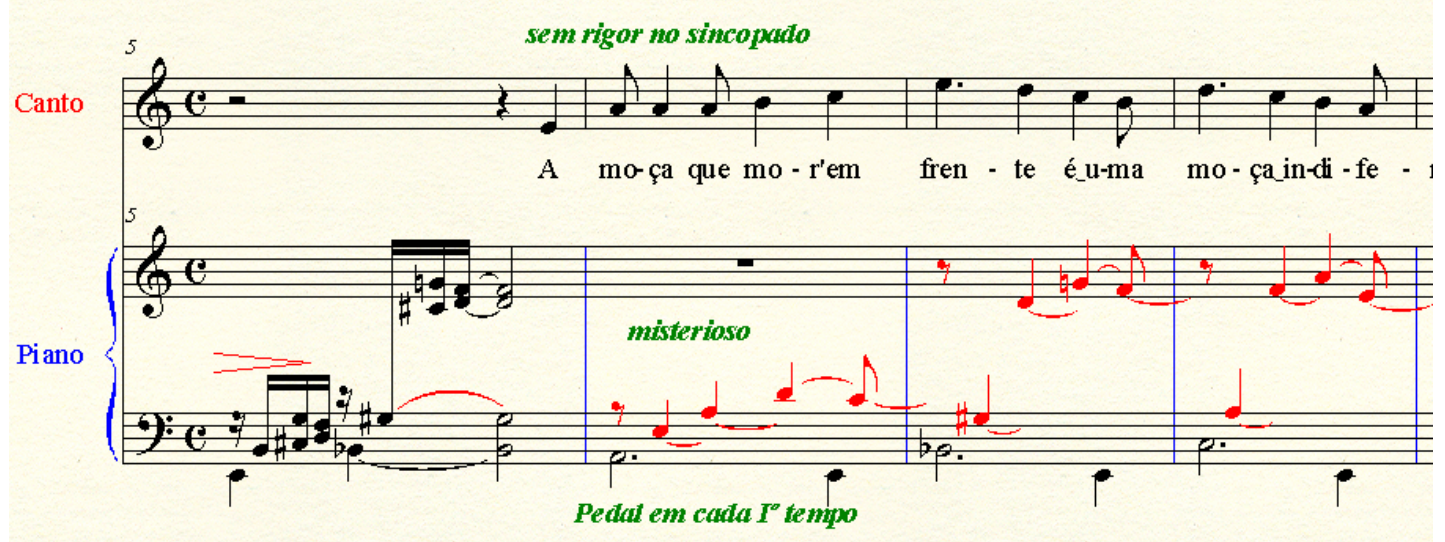

No compasso 27, a figura de acompanhamento modifica-se mais uma vez, com a introdução de acordes na mão esquerda, durante a segunda estrofe do canto, aumentando a densidade do discurso. O tema melódico do canto é formado por dois períodos (com anacruse de semínima) de 4 compassos cada: o Antecedente ascende do Mi2 ao Mi4 e o Conseqüente permanece em torno do Mi grave inicial e é formado pela repetição do mesmo desenho harmonizado diferentemente: na II ve vez, sobre a dominante. Na segunda apresentação do tema, o arco melódico expande-se ao Sol4 e vem descendo até o Sol3 quando é interrompido pelo refrão 
inicial do piano, repetido na íntegra. A segunda estrofe tem um caráter mais mórbido e vai alargando sua tessitura, tanto para o agudo quanto para o grave, até firmar-se sobre o Lá3 central. A linha do canto insere-se na escala de Lá menor natural mas utiliza a sensível Sol sustenido nas terminações. Na conclusão, a sensível superior de 1 tom é utilizada como nas melodias gregorianas ${ }^{72}$ :

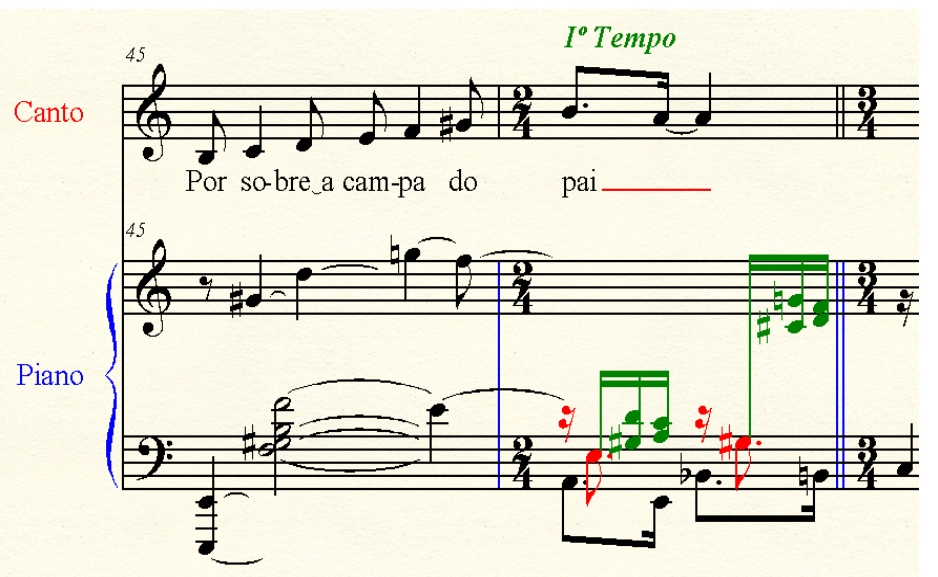

Este procedimento testemunha um dos aspectos essenciais na escrita de Vianna que é a afinidade com a música antiga - medieval e renascencista - presente em toda a sua obra. Todavia, como num quadro de Rembrandt ou de Rubens, partindo de uma unidade estrutural, Vianna busca a diversidade, através do surgimento de vozes em polifonia ${ }^{73}$. O piano é realizado em 4 ou mais vozes independentes, sem deixar de explorar os recursos próprios do instrumento. A parte vocal de Sonâmbula está numa forma binária acrescida de um refrão instrumental que é apresentado no início, no meio e no fim e precede uma codetta de 4 compassos: A-B-A-C-A + coda, sendo que A é instrumental e tem 5 compassos. Por isso, sugere uma forma de rondó, onde o refrão é instrumental e os episódios são vocais, de contornos individuais, e que se utilizam do mesmo material melódico e rítmico.

\footnotetext{
${ }^{72} \mathrm{Na}$ estrutura melódica dos cantos gregorianos, a sensível de sétimo grau ("imperfectio semitoni" de Guido D'Arezzo) não era considerada tão perfeita como a de segunda maior superior (cf. GÉROLD, Théodore. La musique au moyen age. Paris, Librairie Anciènne, 1932, p. 42)

${ }^{73}$ Cf. JEPPESEN, 1939, pp. xi-xiii.
} 
Na Toada $n^{\circ}$ 3, desta vez, o movimento melódico do canto é assumidamente descendente e a indicação "devagar e dolente", do início, reforça a "nonchalance" (indolência) do caboclo que quer casar mas...não muito ${ }^{74}$. Criou-se uma polêmica sobre o andamento adequado para esta canção: a indicação Devagar e Dolente na partitura, sugere um andamento mais lento. Vasco Mariz ${ }^{75}$ considera-a "um pequeno tesouro do lied brasileiro":

Aparentemente monótona, de ritmo uniforme, oferece-nos a imagem perfeita da nonchalance (indolência) típica do caboclo cantador. E Luiz Heitor nela encontrou sugestões, "com seus acordes arpejados e as oitavas agudas, sincopadas, das sonoridades da viola caipira de cordas de arame":

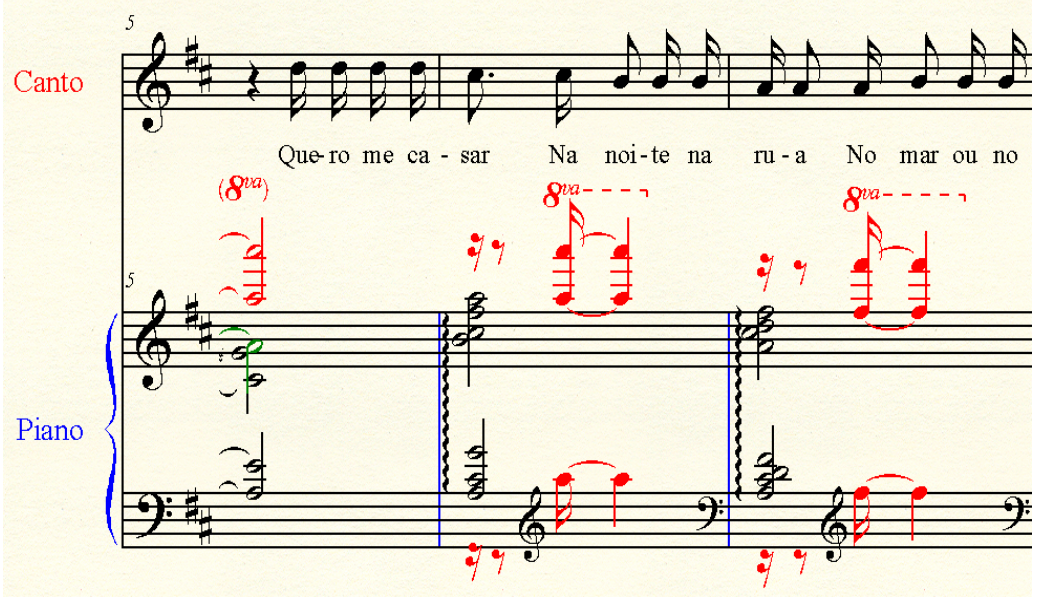

Seus períodos são assimétricos: 0 o tem uma frase de 5 compassos (antecedente) e uma de 4 (conseqüente). Uma terceira frase, isolada, de 3 compassos, coloca o discurso em suspensão e é seguida da mesma figura de acompanhamento introdutório do piano. O segundo período formado por duas frases, dessa vez simétricas, com 4 compassos cada. A primeira tem caráter ascendente e atinge o FÁ4. Na volta, o conseqüente permanece na região média, em torno do LÁ3. Novamente a mesma frase solta reaparece e é completada novamente pela figura de acompanhamento introdutória do piano, para concluir

\footnotetext{
${ }_{75}^{74}$ In CASTRO, 2003, op. cit.

${ }^{75}$ In O Estado de São Paulo, 4 de julho de 1987.
} 
com outra frase solta com função de coda. À semelhança da canção anterior, Sonâmbula, o desenho pianístico serve como introdução, interlúdio e poslúdio, com a novidade da frase solta que suspende o movimento. Nesse caso, a forma é A-B-C-A-D-C-A + coda, onde: A (instrumental de 4 compassos); B (vocal de 3 compassos com anacruse); C (frase solta, suspensiva, de 3 compassos) - A - D (período simétrico de duas frases de 4 compassos cada) - C (frase solta, suspensiva, de 3 compassos) - A (instrumental de 4 compassos) + coda (vocal e instrumental). Em Prenda Minha, Vianna cria uma prelúdio que serve de Introdução e Coda para a singela melodia popular do Rio Grande do Sul, constituindo assim uma forma ternária A-B-A com as repetições típicas entre voz e piano. A partir da entrada do canto, são utilizados arpejos, acordes arpejados e apojaturas, sem porém abandonar a idéia da escrita polifônica, e que constituem um acontecimento paralelo de menor densidade:

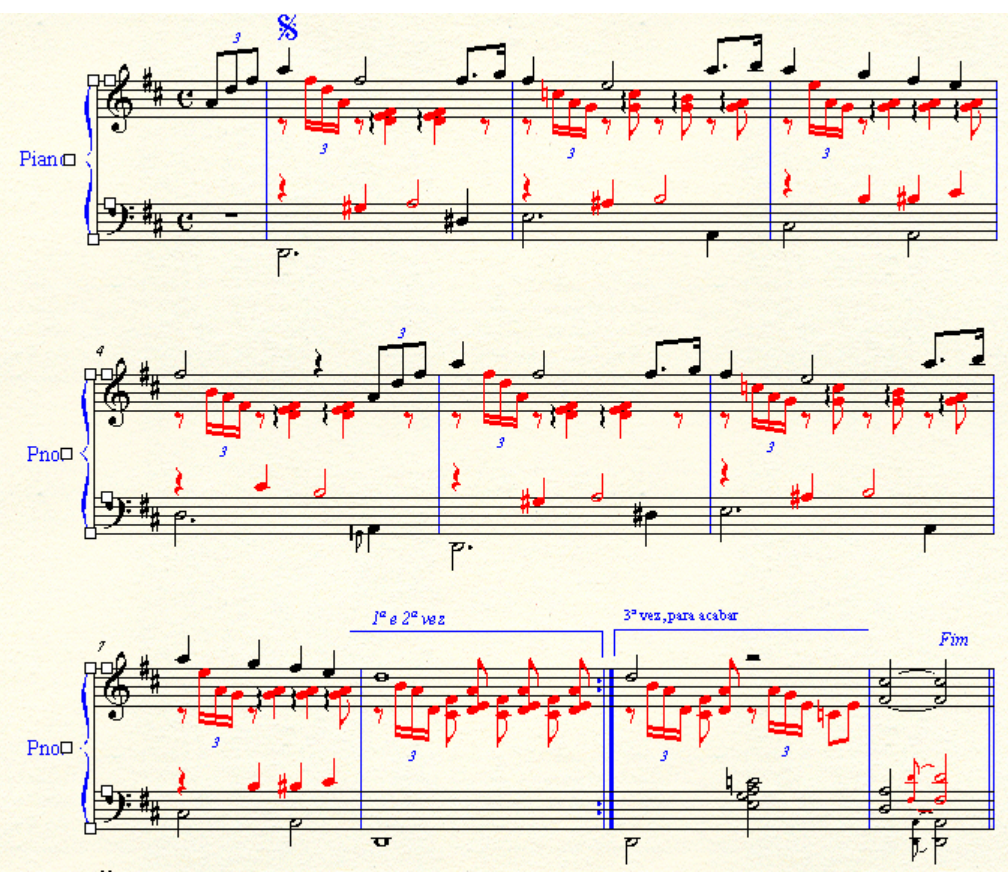

As tercinas arpejadas, que surgem como motivo da introdução, desenvolvem-se ao longo do discurso pianístico formando grupos isolados de quiálteras de sete semicolcheias, arpejos de quatro fusas e quiálteras de cinco fusas, sempre em desenhos que se confundem com os acordes arpejados. 


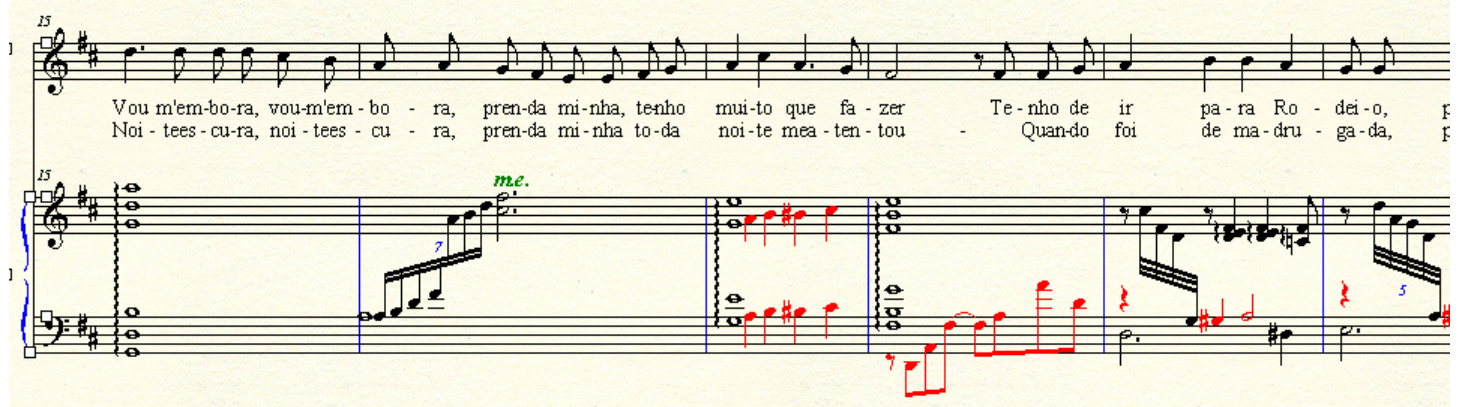

Em Desencanto, com períodos curtos formados por frases de perfis melódicos inversos, os versos surgem ofegantes, quase sem pausa para respiração. A primeira frase começa com salto de sexta ascendente; a segunda com graus conjuntos ou cromáticos descendentes:
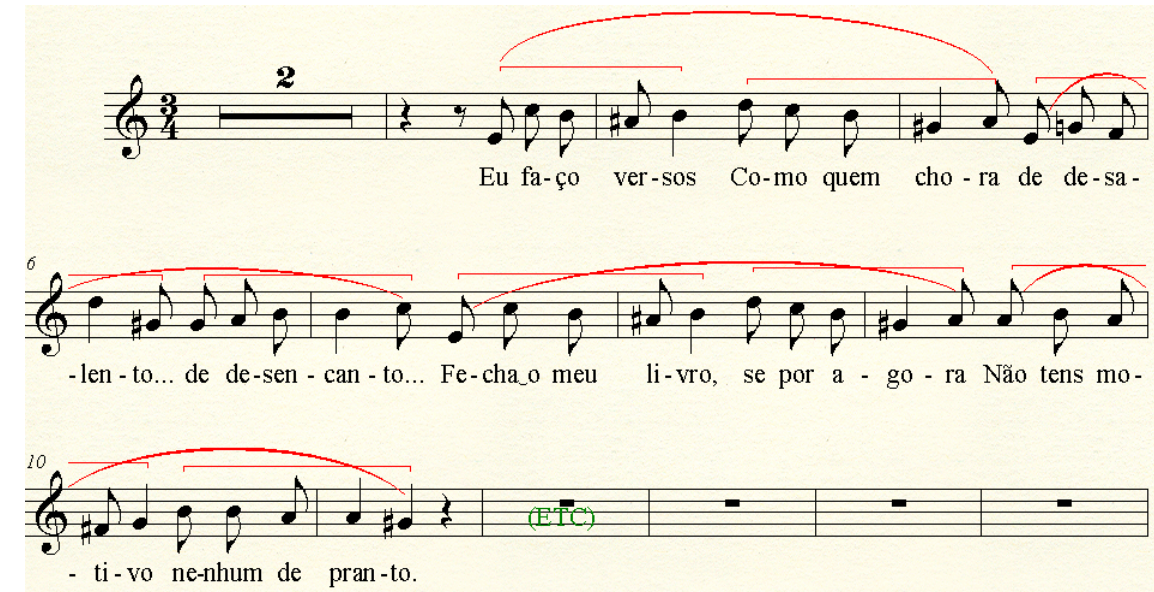

...após a Introdução de arpejos de semicolcheias, com sétima menor e quinta diminuta, num desenho típico das modinhas que também é apresentada como interlúdio, em 20 :

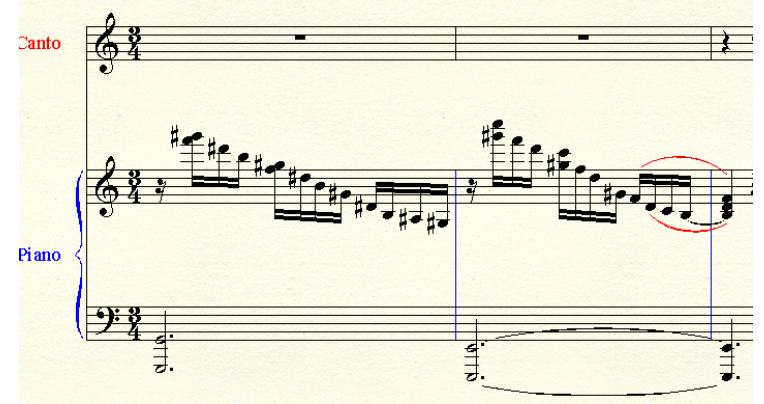


A partir de 17 , a frase inverte-se: o motivo que começava com salto de sexta (MlDO) passa a ser em graus conjuntos ou cromático e o salto disjunto dá-se no $2^{0}$ motivo:

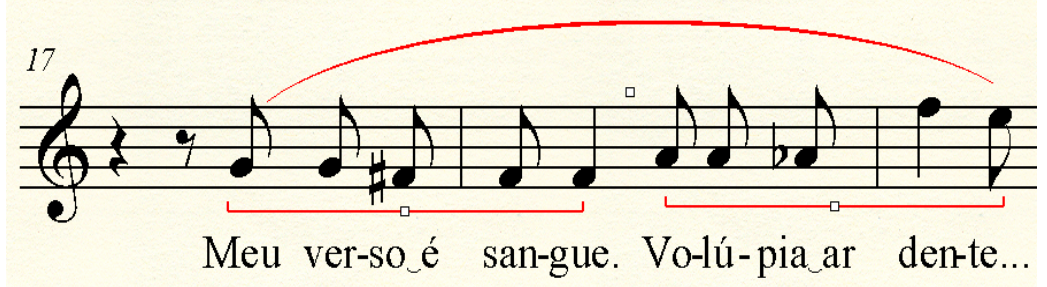

Em 28, após interlúdio pianístico idêntico à introdução, repete-se a frase dos 4 compassos iniciais num quase-recomeçar mas já com caráter conclusivo sobre o $\mathrm{Ml}$ agudo, longo. O motivo inicial expande-se para sétimas descendentes e repetese a frase inicial com repouso sobre o LÁ longo que é absorvido pela sonoridade do piano:
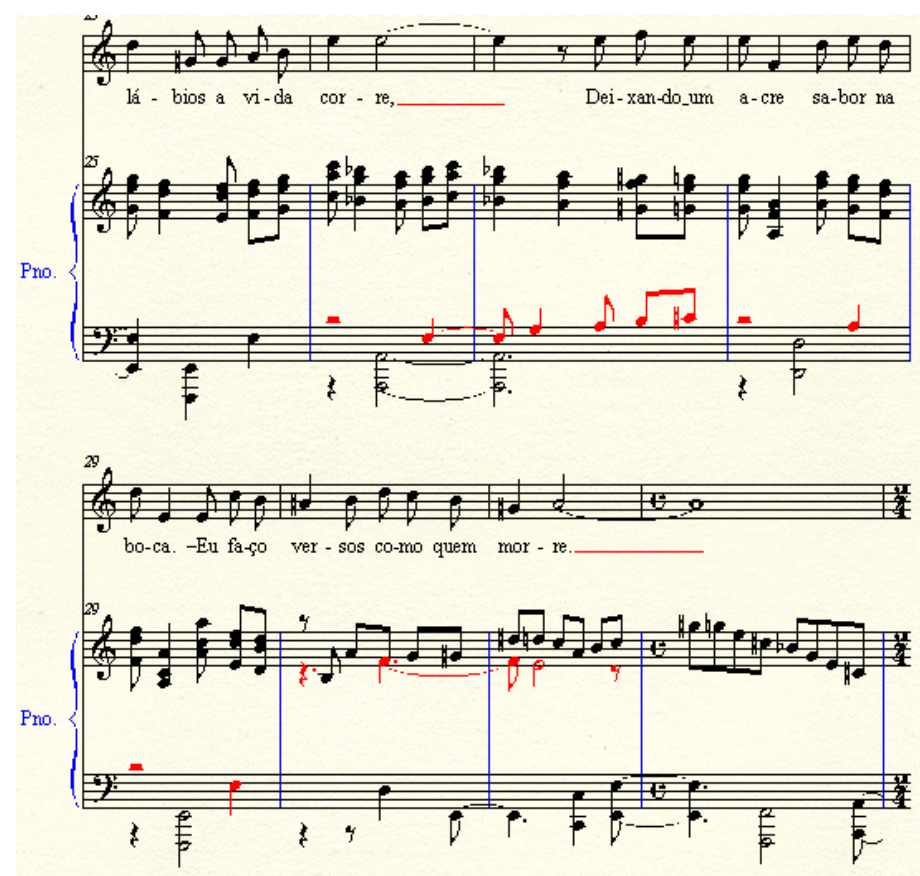
Em Relíquia Apócrifa, o discurso vocal transcorre em pares de frases formando períodos que se alternam entre cadências sobre $T(A m)$ e $D(T r)$ sob uma refinada harmonia do piano que acrescenta sétimas, nonas e quartas ao acorde de LÁ menor, até concluir com uma cadência de engano, aproveitando o LÁ como quinta de um inesperado acorde de RÉ Maior. Partir e ficar tem uma forma A-B-A, onde "A" é instrumental. A voz, que começa com caráter recitativo, vai aos poucos tornando-se mais cantabile, na medida em que seu perfil melódico privilegia os saltos disjuntos de terças e quartas e, no final, até de sétima diminuta, em oposição ao padrão de graus conjuntos do início. When we two parted trata das possibilidades de variação da figura de acompanhamento. Uma introdução de 4 compassos, que tem afinidade com os Intermezzi brahmsianos ${ }^{76}$, expõe os contornos melódicos que a voz irá desenvolver e antecipa a primeira e a segunda figuras de acompanhamento:

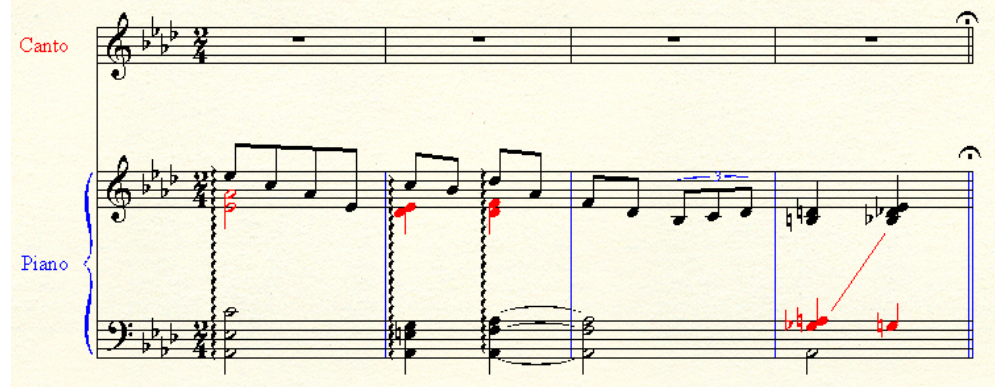

A primeira baseia-se em síncopes sobre um desenho de terças que recaem sobre um motivo escalar descendente para se repetir. Essa figura cobre os dois períodos iniciais da voz, de 8 compassos cada.

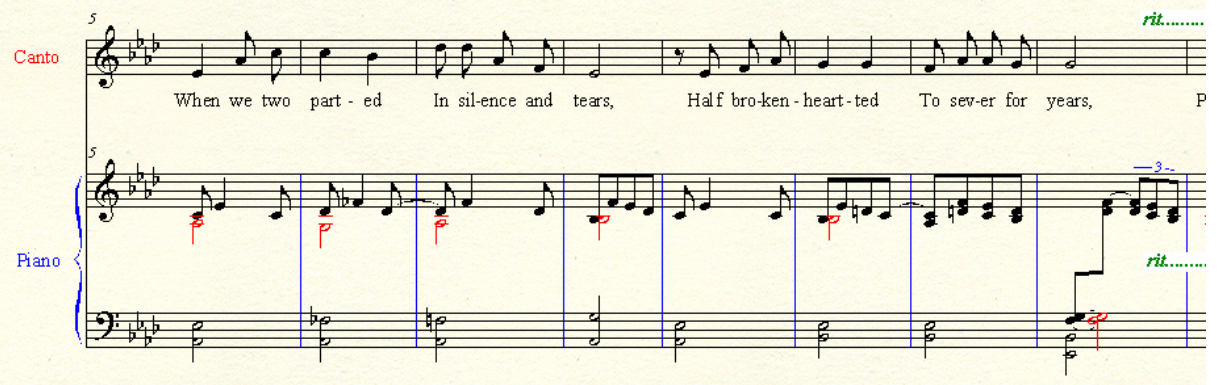

${ }^{76}$ Ver Brahms, op. 18, 끈. 
Uma segunda seção de dois períodos é introduzida pelo canto no anacruse modulatório para 22 e a tercina - que aparecia na introdução e na conclusão do 1 은 período da 1a seção - assume agora um diálogo contrapontístico imitativo numa segunda figura de acompanhamento que é o suporte do primeiro período central, também de 8 compassos:

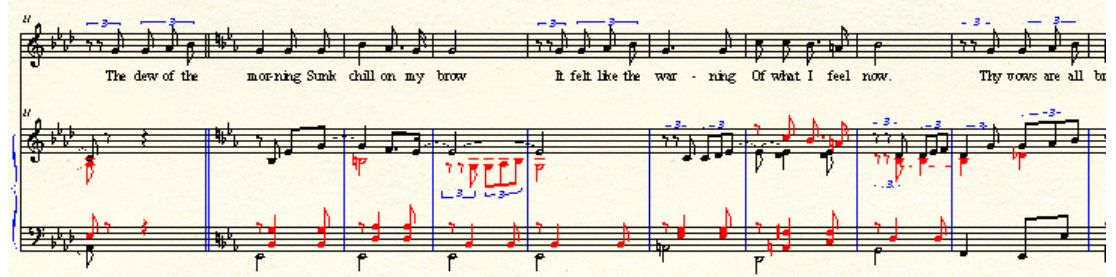

Ao repetir a frase em 29 , uma terceira figura de acompanhamento surge, baseada nas síncopas (como na primeira) com maior densidade devido ao aumento da ocorrência vertical de notas nos acordes. O motivo escalar descendente ganha densidade ao ser acrescido da oitava que vem se somar às terças:

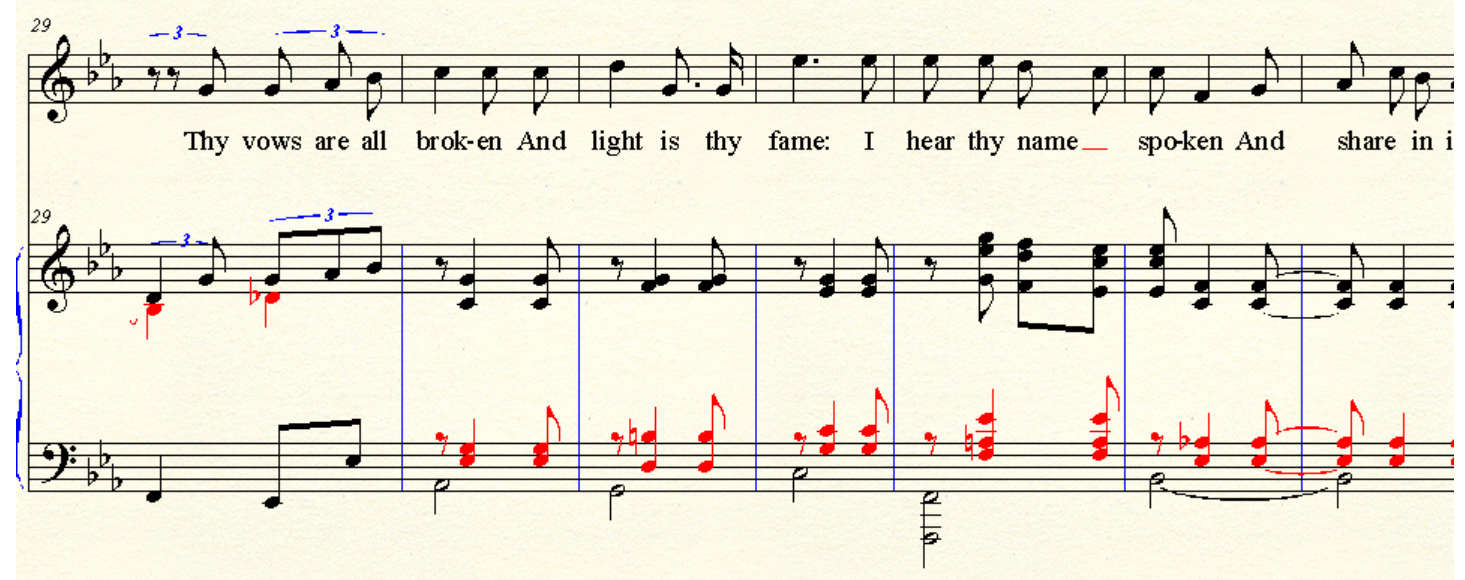

A seção $B$ é repetida em direção ao pico, decorrência da variação da extensão de seu contorno melódico, apoiado pela $2^{2}$ figura de acompanhamento, no primeiro período e, no segundo, a textura se adensa tanto pelas notas agregadas à síncope quanto pelo cruzamento de mão que se dá na transição ( 48-49) : 


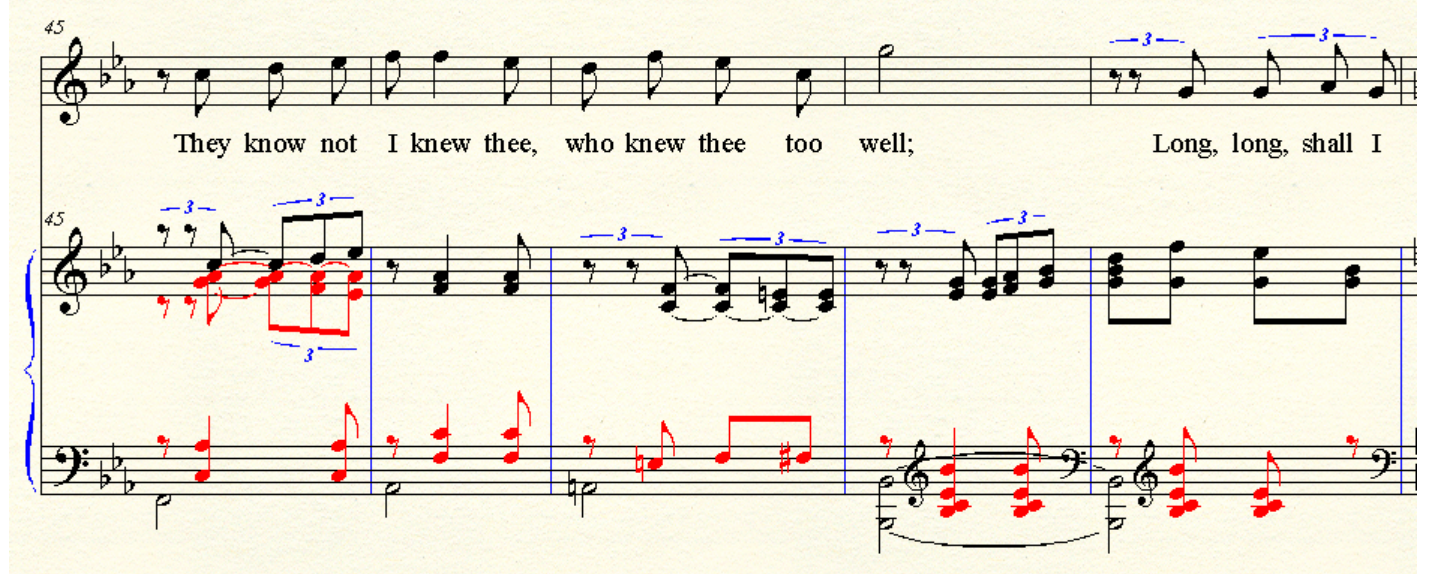

O período que inicia em 45 rompe com a simetria de 8 compassos e prolonga-se durante 11 compassos + fermata, durante o quê é introduzida uma $4^{\underline{a}}$ figura de acompanhamento, mais densa, sincopada, dissonante, ampliando a extensão inicial para uma distância de três oitavas:

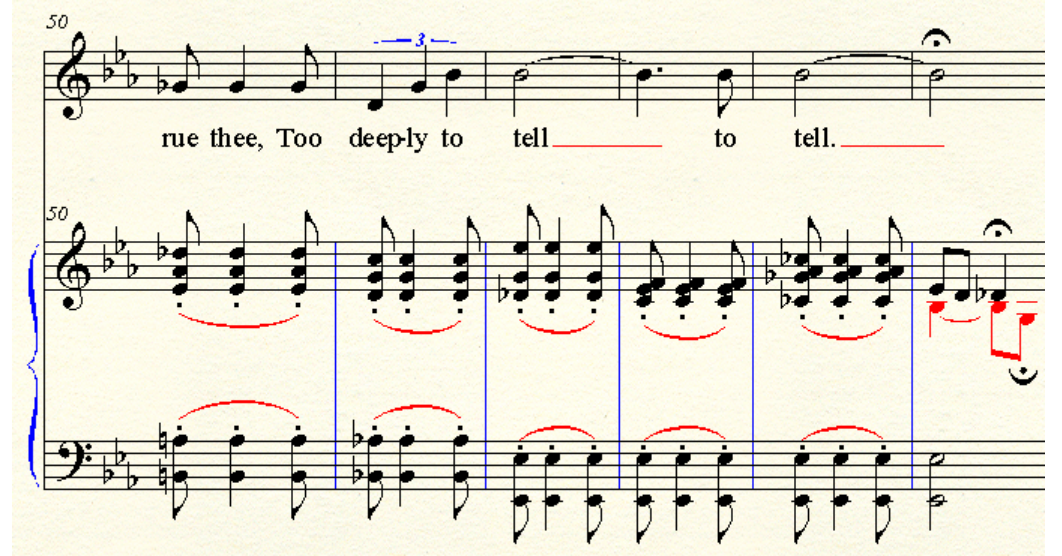

A reexposição de A é realizada com pequenas variações de contorno e seu segundo período tem 10 compassos, acompanhada por uma $5^{\text {a }}$ figura de acompanhamento, arpejada, imitando a harpa numa conclusão que lembra um Fauré, diatônico, sereno e rarefeito: 


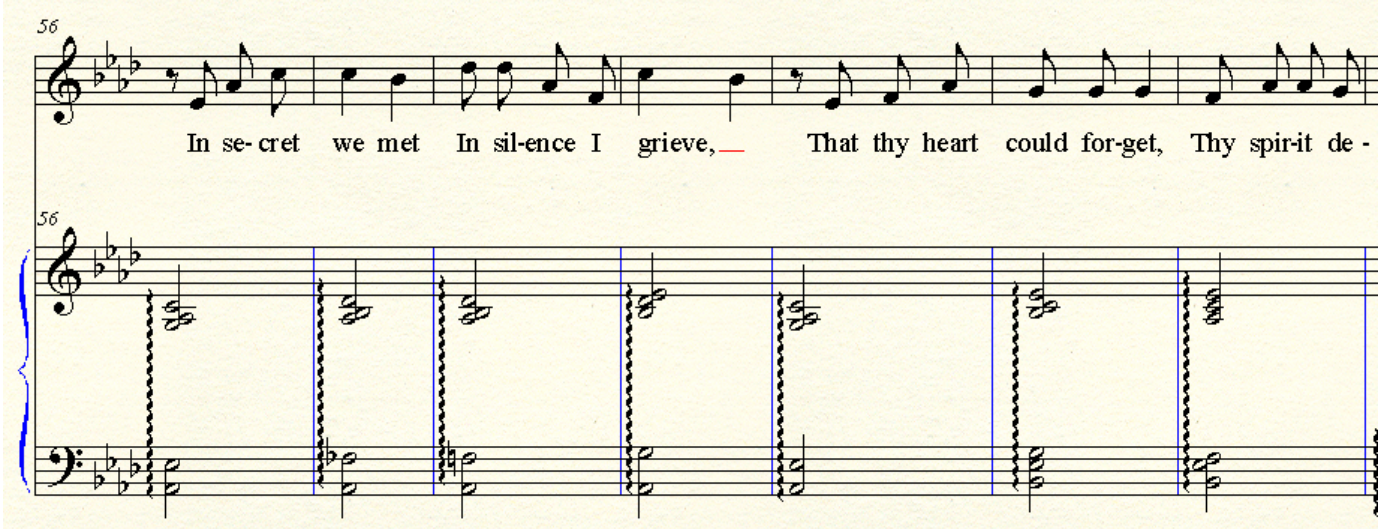

A inspirada melodia da voz basea-se num motivo triádico invertido que sugere uma superposição das quartas Eb-Ab-Db. A idéia da seção B é construída sobre a tercina da introdução e presta-se à improvisação de contornos modulatórios que ensaiam um primeiro pico que se realiza no Ml4 em 32 , concluindo com uma cadência de engano. Ao se repetir, a frase ascende para o pico em SOL4. Na reexposição o piano assume isoladamente uma Coda estrutural com material da $1^{\text {a }}$ figura de acompanhamento em densos e cerrados arpejos, ensaiando uma curta polifonia:

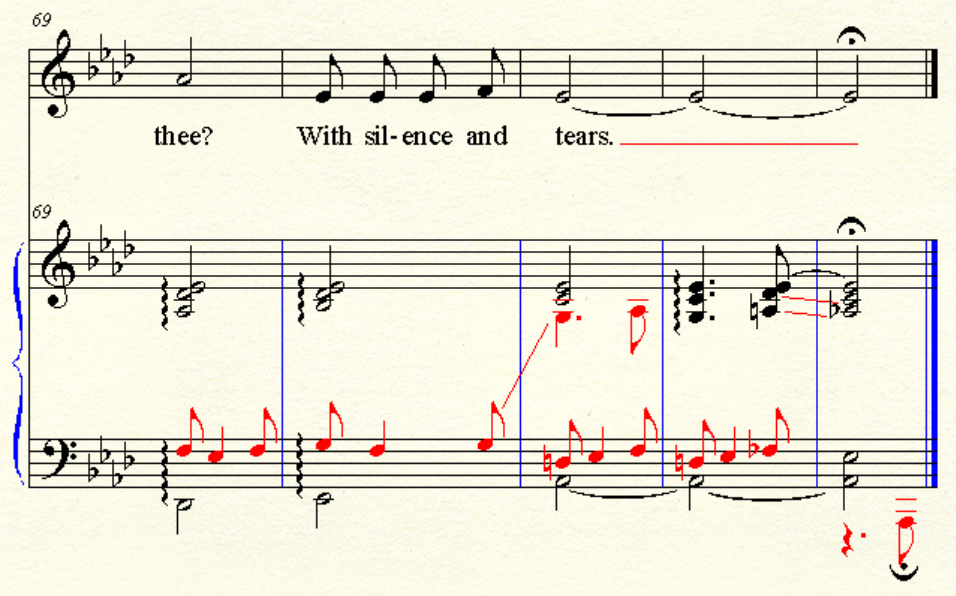

$\mathrm{Na}$ Canção da Jamaica, de uma introdução etérea, de 4 compassos, baseada em quintas, o canto emerge de... uma remota região do universo (provavelmente do astro Sol), em frases assimétricas que variam entre 4 e 3 compassos cada; sendo 
que a fórmula também varia entre $3 / 4$ e $4 / 4$, ora prolongando as terminações ora abreviando-as. O primeiro período de 5 a 12 tem uma semínima a mais de duração no Conseqüente e repousa sobre o tom principal, com cadência perfeita:

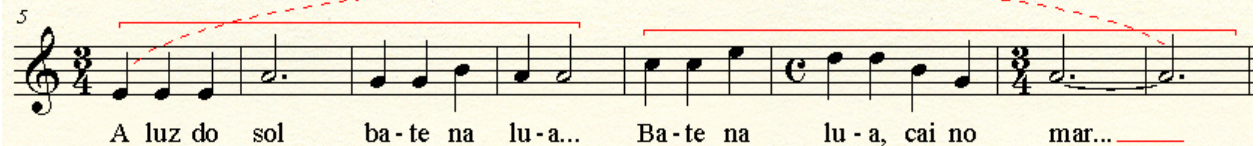

De 13 a 19 , um período assimétrico (de 3 e 4 compassos, isto é: de 10 e 12 tempos de semínima) eleva a extensão do perfil melódico atingindo o pico no SOL4. No movimento descendente da $1^{\underline{a}}$ frase do segundo período, há a ocorrência do Fá \# que transpõe o eólio original para um dórico transposto para LÁ. (Curiosamente, a nota fá não aparece no primeiro período e é a nota que vai determinar o ambiente modal de cada trecho):

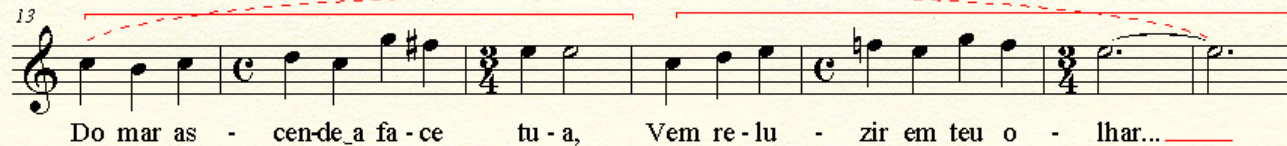

De 20 a 25 , um terceiro período ainda mais assimétrico, desta vez com 3 e 2 compassos (11 e 7 tempos de semínima, devido às mudanças de fórmula) repousa numa cadência imperfeita sobre a nota RÉ, dirigindo-se para a conclusão no quarto período com duas frases de 4 e 5 compassos (13 e 17 tempos de semínima):
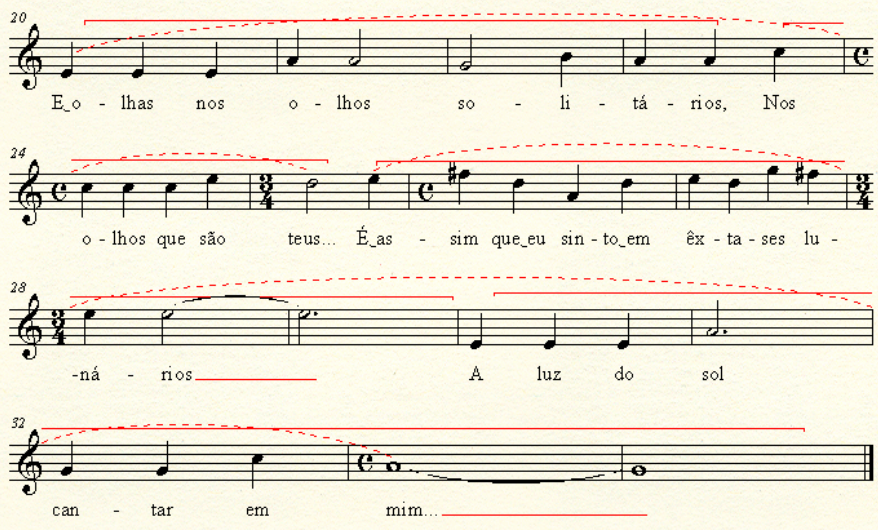
Essa assimetria constitui um verdadeiro labirinto temporal, traduzindo em sons a geometria do percurso da luz desde o Sol até os olhos solitários do poeta (a imagem poética do texto):

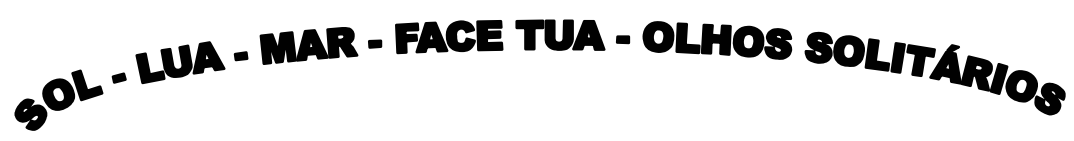

A introdução do piano antecipa o perfil melódico do canto e os acordes do piano se reduzidos a uma mesma oitava, para efeito de análise - indicam aglomerados que orbitam em relação à quinta $\mathrm{E}-\mathrm{B}$, que constitui o repouso harmônico.

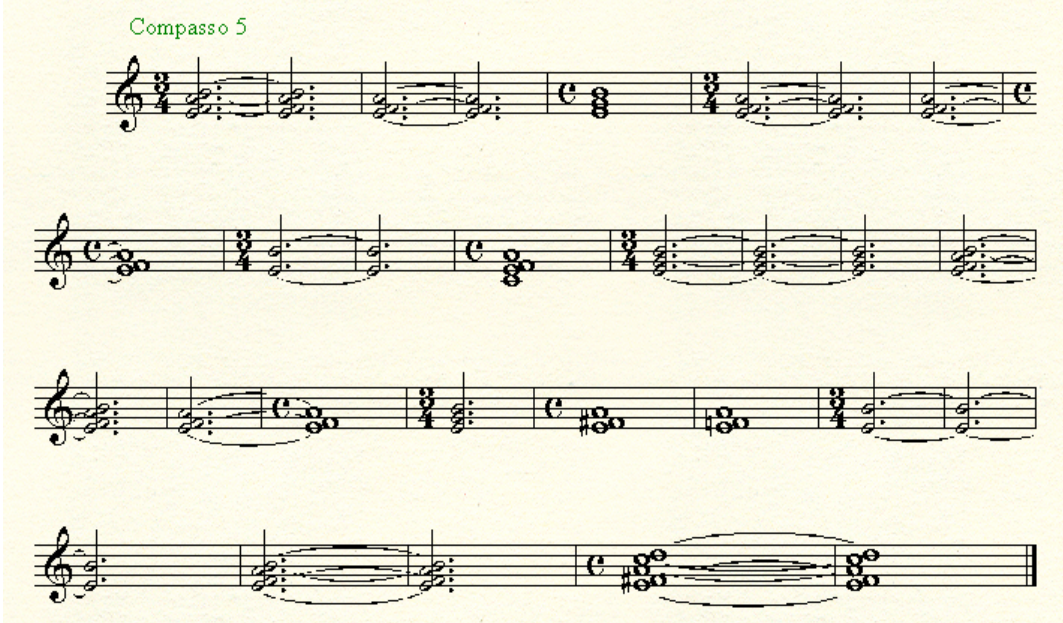

A ausência desse intervalo na conclusão constitui cadência de engano sobre 0 acorde: A-E-F\#-A-C-D-E:

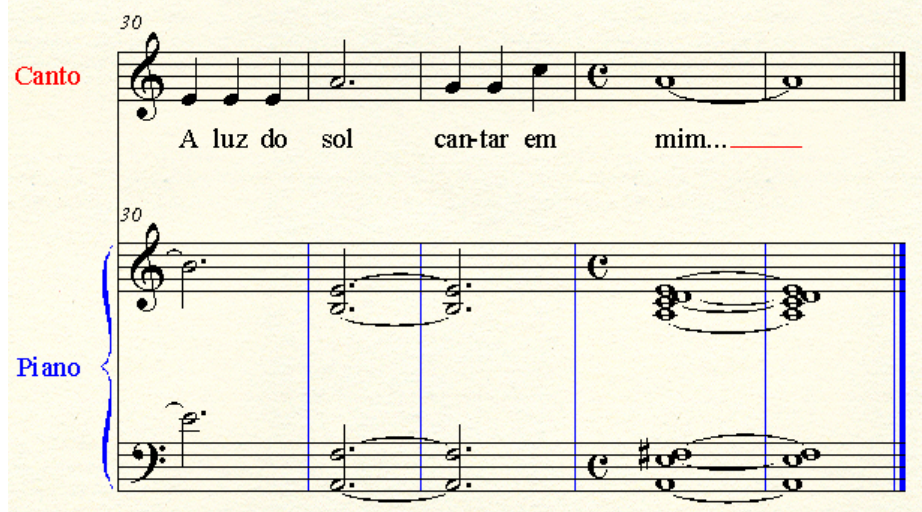


Resume of life lembra um improviso jazzístico. De 1966, esta canção traz uma concepção que aponta para os estilos de Gerswhin e Cole Porter. A utilização sistemática de acordes alterados pede uma análise por cifras. O discurso pianístico traça um caminho improvisatório independente do canto: no primeiro período (de 1 a 4), baseia-se numa escala cromática ascendente com notas pontuadas:

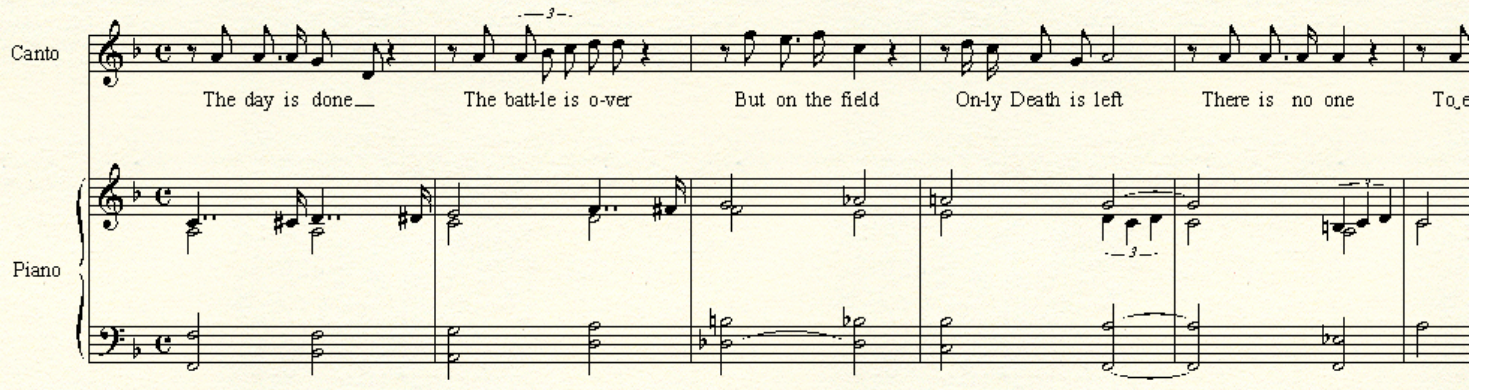

A partir de 4, uma elisão introduz tercinas de semínima que vão-se transformar num movimento escalar repousando sobre o acorde de SI bemol, em 10. Suas pontuações e repousos não coicidem com os da voz, exceto a partir de 13 , quando a escrita pianística assume uma figura de acompanhamento sincopada que dá seqüência à ponte modulatória de $11-12$ e que se vai diluindo na profusão de acordes que aumentam a densidade num movimento cromático ascendente/descendente, desenvolvendo a idéia inicial até a Coda Estrutural a partir de 21.

Ave Maria tem uma introdução harmonicamente "labiríntica" que passa pelos tons de si maior (Dominante), fá sustenido maior (Dominante da Dominante), ré com $7^{\text {ạ }}$ e $9^{\underline{a}}$ (dominante da relativa maior), dó com $7^{\mathrm{a}}$ e $9^{\underline{a}}$ no baixo (Dominante de Fá) para desembocar numa cadência de engano sobre o si maior com sétima, preparando o mi menor - ambiente da canção, tom principal da obra: 


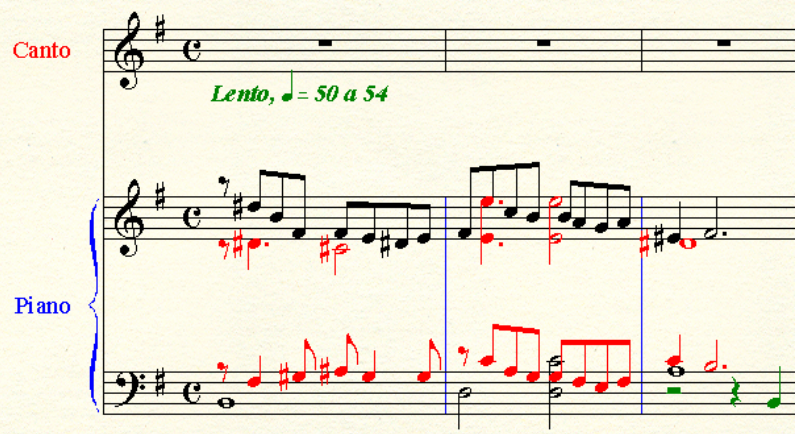

Com a entrada do canto, o piano segue em dois acontecimentos simultâneos: 1) acordes repetidos de duas e três notas; e 2) bordaduras que vão se unir aos baixos a partir de 11, através da tercina que surge como conclusão de sua diluição num movimento descendente:

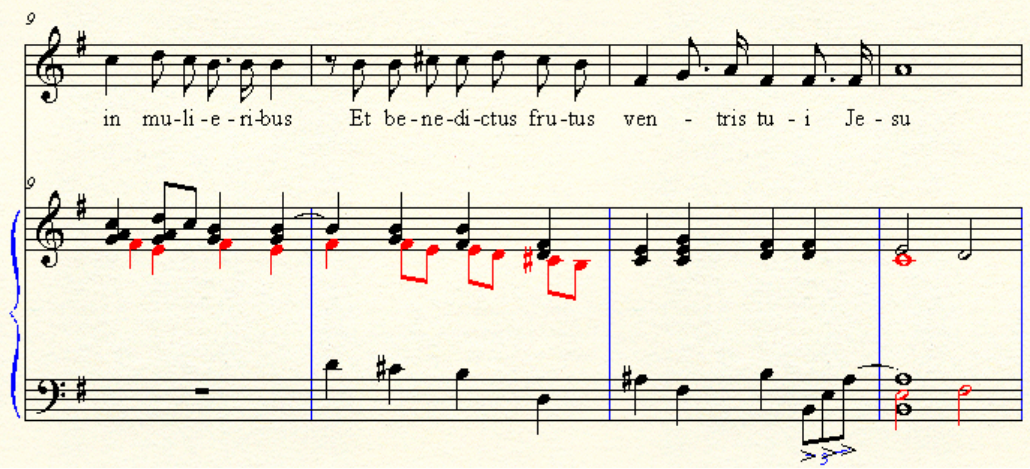

Em 13 , a densidade dos acordes diminui e o andamento acelera ("Poco Piu") para o verso Sancta Maria mater Dei. O que era bordadura ganha independência, ora em tercinas ora em oitavas, aumentando novamente a densidade. Surge uma derivação do motivo:

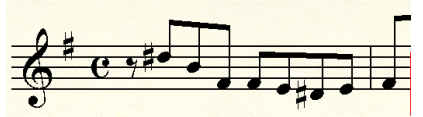

em: 15 :

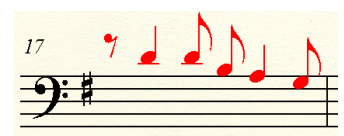


... que compõe com aquele um breve fugato em 15 e 16 justamente no pico melódico do canto (Nunc et in hora mortis nostrae), criando uma polifonia densa...

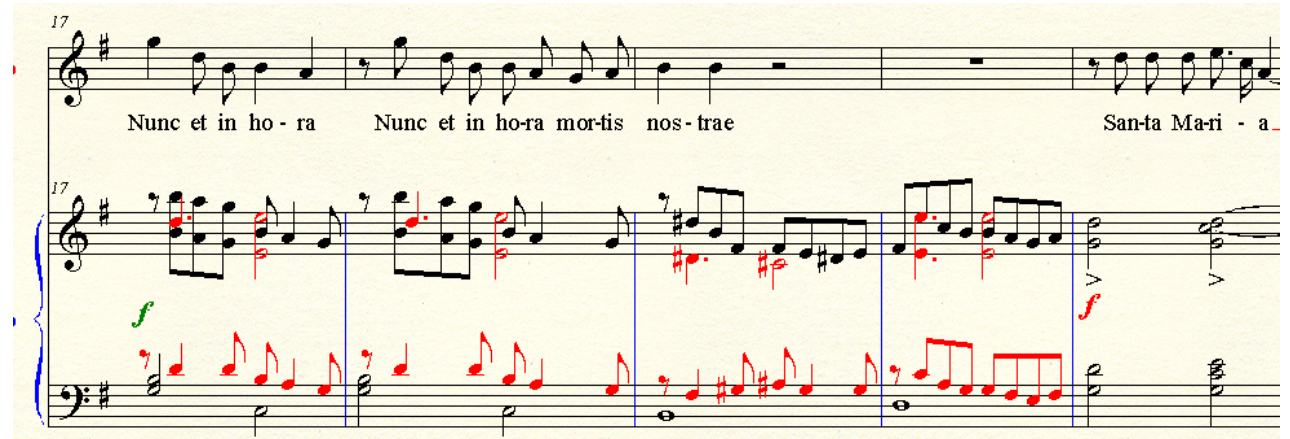

... que resolve nos acordes de 21 (dessa vez sem a cadência de engano, repousando em Sol maior, como pedia a seqüência harmônica), a partir dos quais configura-se no piano uma coda estrutural que retoma os elementos motívicos, enquanto o canto repete o verso também como conclusão ("Sancta Maria, mater Dei, ora pro nobis pecatoribus/ Nunc et in hora mortis nostrae"). Um cromatismo para Mi bemol, quando repete, em 24, o mesmo desenho de 23 meio tom acima, deixando a nota SOL da voz como terça de um acorde de MI bemol com sétima no baixo, antes de retornar ao campo harmônico original de sol maior.

Cadência de engano em 26 sobre si menor e uma sutil e adequada cadência plagal ao final ("Amén"), sobre sol maior, com antecipação da terça e da quinta do acorde (no canto e no piano). :

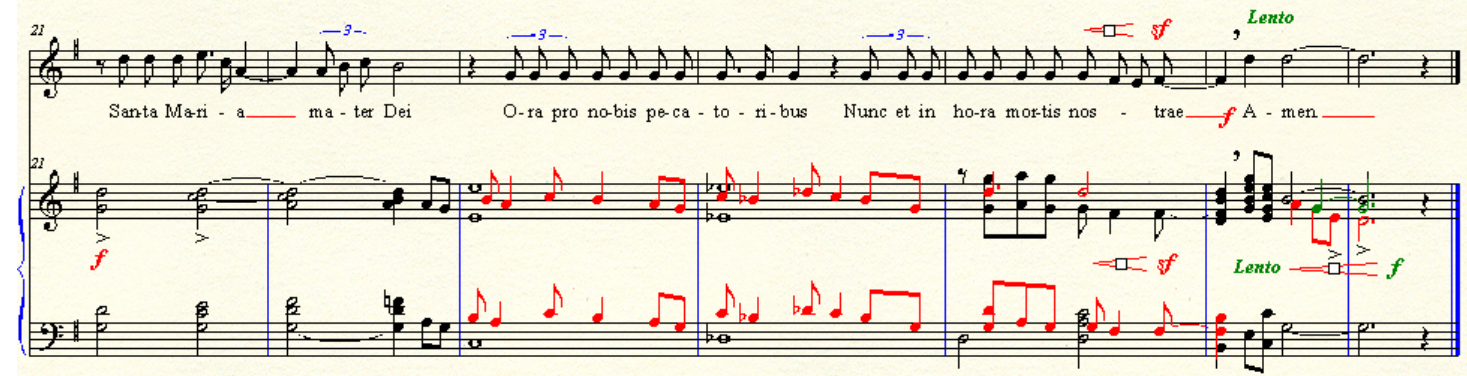




\section{CAPÍTULO 8 - CONCLUSÃO: NÃO É UM COMPOSITOR MENOR!}

O novo raramente é bom, porque o que é bom só é novo por pouco tempo

(Schopenhauer)

Will ich nur halbweg oben bleiben,/ So muss ich jede Messe schreiben ${ }^{77}$

(Tieck)

Vianna construiu seu monumento com material selecionado, trazido de várias fontes. Não se furtou a mergulhar nas diferentes linguagens que conviveram em seu tempo e jamais esqueceu de seu papel na formação da tradição musical brasileira e, sobretudo neste caso, a criação de um gênero de canção típica brasileira. Para isso, lançou mão de poetas significativos como Bandeira, Drummond, Guilherme de Almeida, ao lado de textos populares e folclóricos; completando com outros de sua preferência pessoal como Byron ${ }^{78}$, Augusto de Lima e alguns menos divulgados da literatura nacional ${ }^{79}$; sempre com um distanciamento capaz de transformar o todo "canção" numa obra artística, algumas vezes apesar da fraqueza do texto poético ${ }^{80}$. Como pianista-recitalista, tinha conhecimento pleno de seu instrumento e igualmente conhecedor das possibilidades da voz cantada, elaborou um elenco de canções onde se vêem representados os mais variados matizes da alma nacional: ao mesmo tempo regional e cosmopolita; urbano e caipira; lírico e dramático; introvertido e extrovertido. Se, como já dizia Krieger em 1976, Vianna tem ainda toda uma

\footnotetext{
77 "Se eu quiser apenas me manter à tona,/ Preciso escrever um livro a cada feira".

78 Trata-se da canção When we two parted sobre poema do livro Occasional pieces (from 1807 to 1824). In The complete works of Lord Byron. New York, Thomas Y. Crowel Company, 1927, p. 58.

${ }^{79}$ O texto de Sonâmbula, por exemplo, fui encontrar como "obra especial", referência 00439, na Biblioteca da FFLCH/USP. Trata-se de Contemporâneas (Poesias de Augusto de Lima), prefaciado por Thephilo Dias. Rio de Janeiro, Typographia de G. Leuzinger \& Filhos (Ouvidor, 31), 1887! Curiosamente, no prefácio, Dias fala de "imaginação poderosa, sensibilidade delicada, elocução espontânea, individual e própria”. Embora refira-se à Lima, essas mesmas qualidades encontramos também em Vianna.

${ }^{80}$ Como diz Dieskau: "Toutefois, si le compositeur reste trop près du texte, les faiblesses poétiques n'en ressortent que plus clairement". Op. cit., p. 79. ("Entretanto, se o compositor permanece por demais próximo ao texto, só faz com que as fraquezas poéticas apareçam mais claramente").
} 
"eternidade para crescer ainda mais", este trabalho certamente vai nesse caminho, ao colocar à disposição do público parte significativa de sua produção. Em e-mail de 9 de janeiro de 2007, meu orientador, Prof. Dr. Mario Ficarelli, assim comentou o material que Ihe enviei:

\begin{abstract}
"Caro Marcos Câmara, li com muito cuidado todo o trabalho que me mandou e considero-o bastante bom. (...). Uma coisa porém decepcionou-me um tanto: é o último capítulo - começou bem, mas, quando senti que ia deslanchar para apresentar a sua tese... Ele pára súbito. (...). Em seguida vem a bibliografia e... acaba. Acho que você teria um bocado para dizer dos porquês o Vianna é um compositor maior. Falta pouco, se esforce um pouco mais e faça um gran finale como se deve. Todo o anterior, a situação histórica, os detalhamentos analíticos, as fontes, as citações, tudo vai num crescendo que se espera mesmo a Grande Cadência - a Coda Estrutural onde você reafirmará sua convicção na grandeza de Fructuoso Vianna. Coragem! Falta pouco. Avanti! Um grande abraço do Mario Ficarelli".
\end{abstract}

Diante desse enfático apelo de meu querido Mestre, eu não poderia deixar de pelo menos tentar atendê-lo, ensaiando uma "coda estrutural" à maneira das codas de Beethoven - que muitas vezes parecem começar outra composição, revendo o material exposto e desenvolvido, propondo novos caminhos, dizendo coisas que a Exposição não disse, antes da conclusão propriamente dita. A expressão "não é um compositor menor" é, inclusive, foi cunhada por Ficarelli, num de nossos encontros, e demonstra uma certa indignação daqueles que se preocupam verdadeiramente com nosso patrimônio musical. João Luiz Sampaio ${ }^{81}$ diz: "(...) sua obra não teve melhor sorte. Hoje ainda é um mistério para a grande parte do público de nossas salas de concerto, o que vai de encontro à importância que Vianna teve no cenário musical do século 20 (...)".

No início da década de 80, o Departamento de Música da ECA-USP vivia num clima de Segunda Escola de Viena sob a regência de Willy Corrêa e Gilberto Mendes. Eu, aluno, logo me interessei por Nepomuceno, Villa-Lobos, Glauco Velasquez, Lorenzo Fernadez, Henrique Oswald, Luciano Gallett... Fui causador de polêmicas nas aulas do professor Willy por causa disso. Certa vez, o professor Gilberto Tinetti interrompeu nossa aula de Composição para convidar-nos a assisitir a um recital de seus alunos na "Piscina" do B-9 com a Prole do Bebê, de

${ }^{81}$ Op. cit. 
Villa-Lobos. Willy respondeu: “ - Estamos aqui falando de coisa séria!”. Revolteime, levantei e saí da aula para assistir ao recital, contra aquela orientação monolítica do Departamento. Aos poucos, felizmente, o CMU foi evoluindo e hoje vemos uma mentalidade bem mais pluralista, com professores que professam diferentes poéticas e convivem democraticamente - o que não era absolutamente o caso naqueles tempos.

Quando a música brasileira, com Mário de Andrade, dirigiu-se politicamente para o chamado Nacionalismo, houve um significativo enriquecimento do repertório universal pois acrescentaram-se a esse a alma brasileira, seus ritmos, seus modos, sua harmonia e sua metabolização das influências coloniais mas o que mais me impressionou em Vianna foi a síntese desse processo que ele realizou espontaneamente.

Hoje vivemos certa nostalgia das vanguardas. Lembro que discos de Berio, Nono, Stockhausen, Boulez, Ligeti, Varèse, entre outros, só eram encontrados nas prateleiras de discos importados e era essa vanguarda - que vendeu discos - que formava o substrato das poéticas contemporâneas não-nacionalistas, com 0 suporte messiânico de Koellreutter. Vianna passou à margem dessas poéticas, compondo a música que sua alma de compositor ditava e construiu uma obra que é o reflexo de sua personalidade. Como diz Borges:

...Un hombre se propone la tarea de dibujar el mundo. A lo largo de los años puebla un espacio con imágenes de provincias, de reinos, de montañas, de bahías, de naves, de islas, de peces, de habitaciones, de instrumentos, de astros, de caballos y de personas. Poco antes de morir, discubre que ese paciente laberinto de líneas traza la imagen de su cara ${ }^{82}$.

${ }^{82}$ Epílogo de El hacedor: In BORGES, Jorge Luís. Obra poética, 1923-1977. Buenos Aires, Emecé Editores, S. A., 1977, p. 170. "Um homem se propõe a tarefa de desenhar o mundo. Ao largo dos anos povoa um espaço com imagens de províncias, de reinos, de montanhas, de baías, de naves, de ilhas, de peixes, de habitações, de instrumentos, de astros, de cavalos e de pessoas. Pouco antes de morrer, descobre que esse paciente labirinto de linhas traça a imagem de seu rosto". 


\section{BIBLIOGRAFIA}

ALAIN, Olivier. L'Harmonie. Paris, PUF, 1969.

ANDRADE, Mário de. Ensaio sobre a música brasileira. São Paulo, Livraria Martins Editora, 1972.

ANDRADE, Mário de; Coordenação: ALVARENGA, Oneyda e TONI, Flávia. Dicionário Musical Brasileiro. São Paulo, IEB/USP - EDUSP, 1989.

ÁVILA, Affonso (Coordenação e Organização). O Modernismo. São Paulo, Perspectiva, 1975.

BAIRSTOW, Edward C.. The evolution of musical form. London,. Oxford University Press, 1943.

BERRY, Wallace. Form in Music. Englewood Cliffs, New Jersey, Prentice Hall, 1966.

BORGES, Jorge Luís. Obra poética, 1923-1977. Buenos Aires, Emecé Editores, S. A., 1977.

BRENET, Michel. Palestrina. Paris, Félix Alcan, 1919.

BYRON, George Gordon (Lord Byron). Occasional pieces (from 1807 to 1824). In The complete works of Lord Byron. New York, Thomas Y. Crowel Company, 1927.

CANDÉ, Roland de. Dicitionaire de Musique. Paris, Seuil, 1997.

CASTRO, Marcos Câmara de Castro. Fructuoso Vianna, orquestrador do piano. Rio de Janeiro, ABM Editorial, 2003.

CASTRO, Marcos Câmara de. Fructuoso Vianna, orquestrador do piano. Dissertação de Mestrado apresentada ao Departamento de Música da Escola de Comunicações e Artes da Universidade de São Paulo. Orientador: Prof. Dr. Mario Ficarelli. São Paulo, 2001.

COEUROY, André. La musique et ses formes. Paris, Denoël, 1951.

DAVIE, Cedric Thorpe. Musical Structure and Design. London, Dennis Dobson Ltd., 1953.

FAUSTO, Boris. História do Brasil. São Paulo, EDUSP-FDE, 1997. 
FERRAZ, Silvio. Análise e Percepção Textural. in: Cadernos de Estudo: Análise Musical, n. 3, pp.68-79. S.Paulo, Atravéz, 1990.

FICARELLI, Mario. As sete sinfonias de Jean Sibelius (um estudo sobre as formas e a fraseologia). Tese para Doutoramento apresentada ao Depto. de Música da ECA-USP. São Paulo, 1995.

GÉROLD, Théodore. La musique au moyen age. Paris, Librairie Anciènne, 1932.

GULLAR, Ferreira. Vanguarda e subdesenvolvimento. Rio de Janeiro, Editora Civilização Brasileira, 1978.

HODEIR, André. Les formes de la musique. Paris, P.U.F., 1980.

HOUAISS, Antonio e VILLAR, Mauro de Salles. Dicionário Houaiss da Língua Portuguesa. Rio de Janeiro, Objetiva, 2001.

JEPPESEN, Knud. Counterpoint. New York, Prentice Hall, 1939.

LIMA, AUGUSTO DE. Contemporâneas (Poesias de Augusto de Lima). Rio de Janeiro, Typographia de G. Leuzinger \& Filhos (Ouvidor, 31), 1887.

MARIZ, Vasco. A canção brasileira. Rio de Janeiro, Francisco Alves-ABM, 2002

MORAES, Marcos Antonio de (org.). Correspondência - Mário de Andrade \& Manuel Bandeira. São Paulo, EDUSP/IEB, 2000.

MORRIS, R. O.. The Structure of Music. London, Oxford University Press, 1972.

MUNIZ, Sônia. Fructuoso Vianna: vida e obra. Monografia apresentada ao Projeto Pró-Música, Concurso de Monografia Fructuoso Vianna. Rio de Janeiro, 1984.

NEPOMUCENO, Alberto.: PIGNATARI, Dante (Edição). Canções para voz e piano. São Paulo, EDUSP, 2004.

PAZ, Juan Carlos. Introdução à música de nosso tempo. São Paulo, Duas Cidades, 1976.

PROUT, Ebenezer. Musical Form. London, Augener Ltd, 50th ed., 1893.

RIBEIRO, Darcy. O povo brasileiro: evolução e o sentido do Brasil. São Paulo, Companhia das Letras, 1995. 
RIEMANN, Hugo. Composición Musical. Barcelona, Editorial Labor S.A., 1943.

RIEMANN, Hugo. Fraseo Musical. Barcelona, Editorial Labor S.A., 1936.

SCHAEFFER, Paul. Traité des objets musicaux. Paris, Seuil, 1966.

SCHOLES, Percy. The concise Oxford Dictionary of Music. London, OUP, 1960.

SCHUMANN, Robert. Lieder, Band I. London, Frankfurt, New York, Edition Peters.

SCLIAR, Esther. Elementos de teoria musical. São Paulo, Novas Metas, 1986.

SIMPSON, Robert (Edited by). The Symphony, vol. I Haydn to Dvorák. Penguin Books Ltd, Harmondworth, 1975.

STUCKENSCHIMIDT, H. H.. La música del siglo XX. Madrid, Guadarrama, S.A., 1960.

TOVEY, Donald Francis. The forms of music. London, OUP, 1957.

WHITE, John D.. Comprehensive Musical Analysis. Lanham, Maryland and Oxford, The Scarecrow Press, Inc., 1994.

WISNIK, José Miguel. O som e o sentido. São Paulo, Cia. das Letras, 1989. ZAMACOIS, Joaquín. Curso de formas musicales. Barcelona, Editorial Labor, 1960.

ZUBEN, Paulo. Ouvir o som. Cotia, Ateliê Editorial, 2005. 


\section{ANEXO 1: A INTEGRAL DAS CANÇÕES}

Todas as canções de Vianna foram por mim revisadas, editadas e digitalizadas, com a utilização do software Finale 2006 (MakeMusic Inc.). As fontes estão no Acervo Fructuoso Vianna da seção Multimeios da ECA/USP e o acesso a elas contou com a boa vontade das bibliotecárias Sílvia e Marina. Entre manuscritos do autor, edições de época e cópias manuais, destacam-se as cópias realizadas por Aída Gnatalli - irmã do célebre compositor e arranjador Radamés - por encomenda das irmãs Anna Maria e Guigui. Outras, menos profissionais, também foram consultadas. Sempre que houve alguma dúvida, a própria Guigui foi solicitada, já que, como pianista amadora, conhece a fundo a obra de seu pai. A integral das canções consta de 23 peças:

\begin{tabular}{|c|c|c|c|c|}
\hline ANO & TÍTULO & $\begin{array}{c}\text { № DE } \\
\text { PÁGINAS }\end{array}$ & FONTE & TEXTO \\
\hline 1928 & Sonâmbula & 5 & $\begin{array}{c}\text { Ed. } \\
\text { Chiarato }\end{array}$ & Augusto de Lima \\
\hline 1930 & Toada $n^{\circ} 3$ & 4 & $\begin{array}{l}\text { L. G. } \\
\text { Miranda }\end{array}$ & $\begin{array}{c}\text { Carlos Drummond de } \\
\text { Andrade }\end{array}$ \\
\hline 1932 & Refrão do Mutum & 4 & MS & Popular \\
\hline \multirow[t]{4}{*}{1938} & Sem-fim & 5 & $\begin{array}{l}\text { Edição do } \\
\text { autor }\end{array}$ & Popular \\
\hline & Sabiá & 5 & $\begin{array}{l}\text { MS do } \\
\text { autor }\end{array}$ & Cássio Mota \\
\hline & Prenda Minha & 3 & $\begin{array}{l}\text { MS do } \\
\text { autor }\end{array}$ & Popular \\
\hline & Ma Malía & 7 & $\begin{array}{l}\text { MS do } \\
\text { autor }\end{array}$ & Popular \\
\hline 1939 & Chula Paraoara & 5 & MS & Popular \\
\hline 1948 & Desencanto & 3 & MS & Manuel Bandeira \\
\hline
\end{tabular}

${ }^{83}$ Na presente edição. 


\begin{tabular}{|c|c|c|c|c|}
\hline ANO & TÍTULO & $\begin{array}{c}\text { № DE } \\
\text { PÁGINAS }^{83}\end{array}$ & FONTE & TEXTO \\
\hline 1951 & $\begin{array}{l}\text { Seis canções } \\
\text { trovadorescas } \\
\text { 1) Cantar galego } \\
\text { 2) Partir e ficar } \\
\text { 3) Bailía } \\
\text { 4) Cantiga dos } \\
\text { Olhos que } \\
\text { Choram } \\
\text { 5) Vilancete } \\
\text { 6) Relíquia } \\
\text { apócrifa }\end{array}$ & 28 & $\begin{array}{l}\text { MS do } \\
\text { autor }\end{array}$ & Guilherme de Almeida \\
\hline \multirow[t]{2}{*}{1955} & Madrigal & 4 & MS & $\begin{array}{c}\text { Tradução de Guilherme } \\
\text { de Almeida do texto de } \\
\text { um Madrigal de } \\
\text { Palestrina }\end{array}$ \\
\hline & $\begin{array}{l}\text { Peregrinos do } \\
\text { Joazeiro }\end{array}$ & 4 & $\begin{array}{l}\text { MS do } \\
\text { autor }\end{array}$ & Popular \\
\hline 1957 & Un Ami & 5 & $\begin{array}{l}\text { MS do } \\
\text { autor }\end{array}$ & Regina Chagas Pereira \\
\hline \multirow[t]{2}{*}{1962} & $\begin{array}{c}\text { Modinha de Xisto } \\
\text { Bahia }\end{array}$ & 5 & $\begin{array}{l}\text { MS do } \\
\text { autor }\end{array}$ & $\begin{array}{c}\text { Xisto Bahia/Plínio de } \\
\text { Lima }\end{array}$ \\
\hline & $\begin{array}{l}\text { When we two } \\
\text { parted }\end{array}$ & 6 & $\begin{array}{l}\text { MS do } \\
\text { autor }\end{array}$ & Lord Byron \\
\hline \multirow[t]{3}{*}{1966} & $\begin{array}{l}\text { Canção da } \\
\text { Jamaica }\end{array}$ & 3 & $\begin{array}{l}\text { MS do } \\
\text { autor }\end{array}$ & Manuel Bandeira \\
\hline & Resume of life & 3 & $\begin{array}{l}\text { MS do } \\
\text { autor }\end{array}$ & $\begin{array}{c}\text { Regina de Chagas } \\
\text { Pereira }\end{array}$ \\
\hline & Ave Maria & 3 & $\begin{array}{l}\text { MS do } \\
\text { autor }\end{array}$ & Texto litúrgico \\
\hline
\end{tabular}

